Portland State University

PDXScholar

$11-21-1985$

\title{
Each in Its Own Sphere: Religion and Law in Oregon History
}

Alan L. Gallagher

Portland State University

Follow this and additional works at: https://pdxscholar.library.pdx.edu/open_access_etds

Part of the History of Religion Commons, and the Political History Commons Let us know how access to this document benefits you.

\section{Recommended Citation}

Gallagher, Alan L., "Each in Its Own Sphere: Religion and Law in Oregon History" (1985). Dissertations and Theses. Paper 3575.

https://doi.org/10.15760/etd.5459

This Thesis is brought to you for free and open access. It has been accepted for inclusion in Dissertations and Theses by an authorized administrator of PDXScholar. Please contact us if we can make this document more accessible: pdxscholar@pdx.edu. 
AN ABSTRACT OF THE THESIS OF Alan L. Gallagher for the Master of Arts in History, presented November $21,1985$.

TITLE: Each In Its Om Sphere: Religion and Law in Oregon History APPROVED BY MEMBERS OF THE THESIS OOMMITTEE:

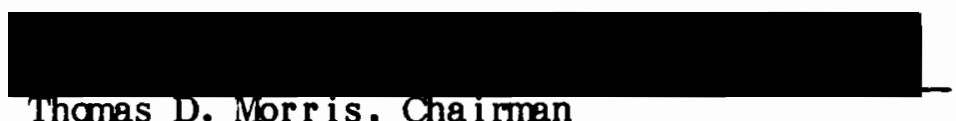

Thamas D. Vor is, Cha 1 rman

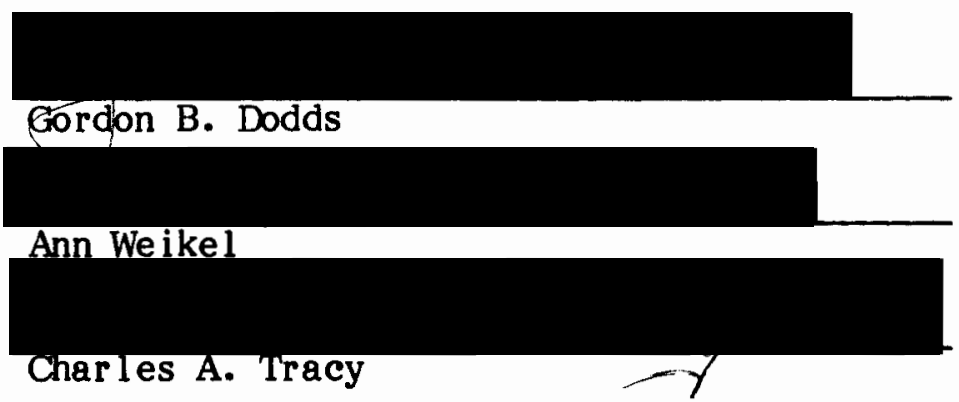

The author employs research skills from law, history and religion in order to present an account of the relations of law and religion in Oregon's history from its earliest days to the present.

Oregon is considered by its leading historians to be affected periodically by religious and racial prejudice. The salient example is the period of $\mathrm{Ku}$ Klux Klan dominance in the 1920 s and the Oregon School Bill. The management of church-state relations has generated a larger number of cases and controversies than most lawyers and historians realize. Using techniques and insights employed by historian-lawyers such as Mark DeWolf Howe and Orville Zabel, the author examines in detail, case by case and sect by sect, the development of principles of church-state relations in Oregon. Zabel, in his history of Nebraska's church-state development, had opined that Nebraska's history was that of the nation writ small. He concluded that American jurisdictions had essentially followed a common path. The Oregon 
example suggests otherwise. Howe has demonstrated the wide variety of forms church-state management took in American jurisdictions and suggested a rationale for some convergence among the States in form.

However, what each demonstrates upon examination is how each jurisdiction had a wide range of choices, and that wide experimentation was and continues, in spite of the homogenizing pressures of the federal courts, to be the rule.

Howe predicted that the concept of equality of treatment, which he saw as the dominant theme of 20th Century law and politics, would have the effect of so broadening the definitions of religious groups as to eventually remove the protections afforded them when the definition was more narrow.

Finally, in recent years the United States Supreme Court, reversing a pattern of at least thirty years, has begun to defer again to the States in such Constitutional areas as religion. States, Oregon being a leading example, have responded with increasingly independent interpretations of their own Constitutions. This reversion to state court law-making has created a need for detailed state histories of religion and law.

The author presents the major themes, events and persona of Oregon's legal-religious history. He examines education, enforcement of morality, taxation and exemption, the treatment of minority religious groups, and the rise of professional interest groups. Legal sources such as court decisions, Attorney General opinions and statutes are assembled, assessed and annotated. Church histories, theses on Oregon religious groups, biographies and memoirs of leading actors are carefully reviewed. Special attention is given to Oregon's 
Constitutional development on religion and to the Oregon School Bill, which set a national precedent for religious liberty while simultaneously expanding the federal role.

The author concludes that a combination--the expansion of the roles of state and federal governments, the rise in taxation, religious prejudice (especially anti-Catholic prejudice), the progressive secularization of legal rationales and public fora, the impulse to equalize treatment of religious and non-religious groups--have all converged in Oregon. That combination has left the law in appearance and in fact not only unfriendly to religion, but in many areas seemingly on the attack against it. Because U.S. Supreme Court decisions establish a minimum to which states must adhere, state independence can only be directed toward further restriction of religion. Whatever the reality, state institutions will therefore appear to be more unfriendly than the federal. The general animus against special deference to religious groups overarches and contributes to the special actions which, when taken against this church or that, seem to display only special bias. While anti-Catholic prejudice, e.g., is real and important, it is not sufficient explanation for the state's persistent extreme separationist trend.

The author suggests that a correct reading of the history of Oregon Constitutional foundations and of the practices of its people should result in a more accommodationist attitude on the part of Oregon's legal entities. 


\title{
EACH IN ITS OWN SPHERE:
}

\section{RELIGION AND LAW IN OREGON HISTORY}

\author{
by
}

Alan L. Gallagher

A thesis submitted in partial fulfillment of the requirements for the degree of

\author{
Master of Arts \\ in \\ History
}

Portland State University

1985. 
TO THE OFFICE OF GRADUATE STUDIES AND RESEARCH:

The members of the Cormittee approve the thesis of

Alan L. Gallagher presented November 21, 1985.

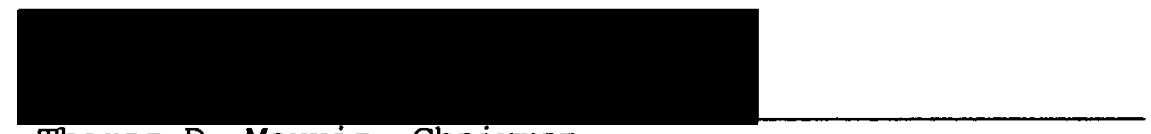

Thomas D. Morris, Chairman

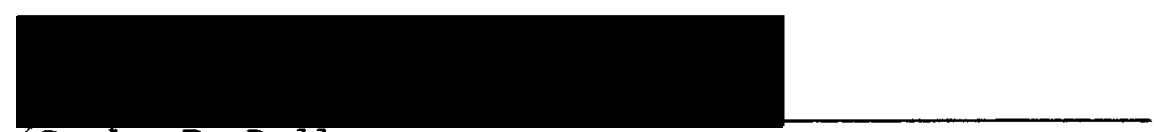

Gordon B. Dodds

(

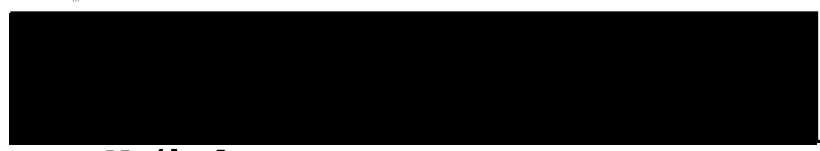

Ann Weikel

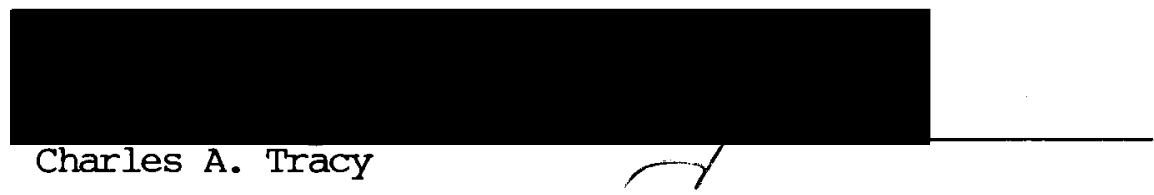

APPROVED:

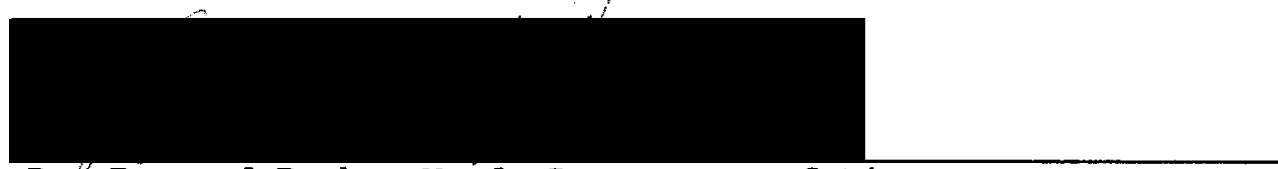

Dr/ Bernard Burke, Head, Department of History

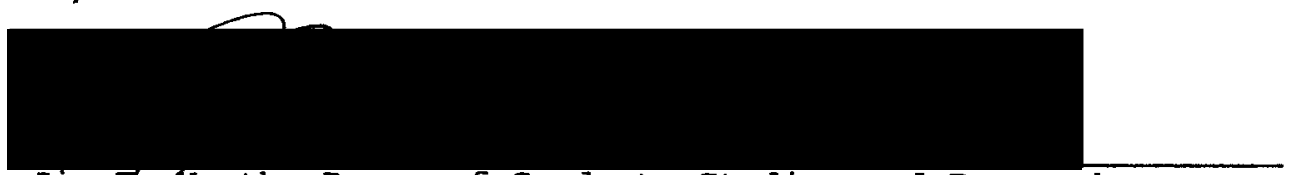

Jim F. Heath, Dean of Graduate Studies and Research 
Chapter

\section{TABLE OF CONTENTS}

Int roduction............................... I

I. Prologue................................. 9

II. The Federal Background........................ 13

I I . Oregon Const itut ional Development ................. 20

IV. Private Parties, Churches, and the State................ 38

(a) Charitable Immunity (b) Intra-Church Litigation.

V. Taxat ion................................

VI. The Oregon School Bill of $1922 \ldots \ldots \ldots \ldots \ldots \ldots \ldots \ldots \ldots \ldots$

VII. Dissident and Minority Churches................... 71

(1) The Catholic Church

(2) Early Churches

(3) Christian Scientists

(4) The Peace Churches

(5) Jehovah's Wi tnesses

(6) Jews

(7) The International Society for Krishna Consciousness ("Hare Krishnas").

(8) Ethnic Churches

(9) The Church of Scientology

(10) The World Church for the Unification of Christianity (The "Mbonies")

(11) The Bhagwan Shree Rajneesh and his followers ("Rajneeshees")

(12) Protestants and Other "Majorities"

(13) Seventh Day Advent ists

(14) Other Groups and Cases

VIII . Education................................... 94

IX. A Confusion of Actors.......................... 105

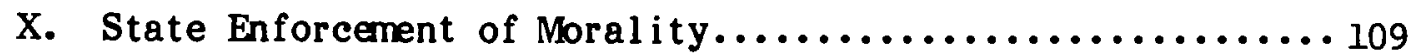

XI. Conclusion................................ $\ldots 17$

XII . Notes.................................... 
XII I. Sources:

(a) Bibl iographical Essay .......................... 136

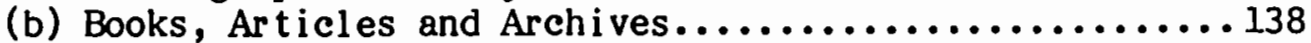

(c) Cases ....................................... 146

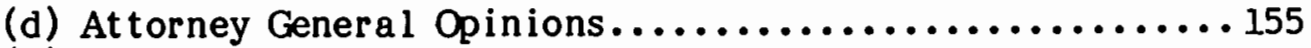

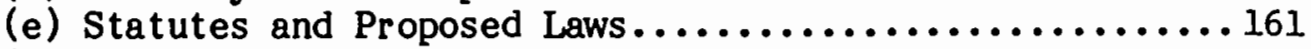

(f) Law Review Articles............................. 164

(g) Interviews/Speeches ........................ 166

\section{NOTE}

Oregon cases, opinions, laws, and law review articles are given in the bibliography with full citation and annotation. This information is not repeated in the text save where necessary. The reader should refer to the bibliography for fuller information on sources, using the name of the case, or the year for Attorney General Opinions and laws. 
"...the religion clauses of the First Amendment were intended to erect "a wall of separation between church and state"...(which) must remain "high and impregnable"".

Jefferson's Danbury Letter and Everson 1

"the line of separation, far from being a 'wall', is a blurred, and indistinct, and variable barrier depending on all the circumstances of a particular relationship."

Chief Justice Burger in Lemon²

"Something there is that doesn't love a wall."

Robert Frost, Mending Wall ${ }^{3}$ 


\section{INTRODUCTION}

Historically the church-state controversy has been in the United States largely confined to the state level. 4 Only in the years since 1941 has the area of church-state matters become federalized through decisions of the United States Supreme Court. 5 Recently, however, that court has seemed to be adopting a more accommodationist role. It has deferred to the states in this and other constitutional areas. The result has been an increased attention to the resolution of church-state matters within the states.

This thesis presents a summary of Oregon history relating to the interaction of law and religion, and presents analysis of the causes of the major events and trends. In so doing, it seeks to show the proper approach and mix of disciplinary skills needed for the handling of such a history.

There have been surveys of church-state law on a national basis. Sanford Cobb's 1902 The Rise of Religious Liberty 6 is a good survey not only of the law at that time but, as importantly, of the conceptions then prevailing of the nature and sources of that law. It was clear to Cobb, as to the leading 19th century scholars, that the federal constitution did not apply to the states and that states had a wide range of discretion in how they managed church-state relations. Carl Zollman's 1933 American Church Law 7 reassessed legal developments: in 1933, church-state law was still a matter for regulation by the states only. In the 1940s Anson Phelps Stokes published Church and State in the United States, ${ }^{8}$ a strongly separationist history which began to identify the federal intervention into church-state law. In later editions, co-quthor Leo Pfeffer of the American Jewish Congress, a noted separationist lawyer and scholar, would update the work and emphasize 
separationist themes and trends.

Other surveys, such as those of Charles Antieu, Religion Under the State Constitutions (1955) and Conrad Moehlman's The American Constitutions and Religion (1938) provide basic data and some good but dated analysis. ${ }^{9}$

Writers on church-state relations in the past three decades have largely focused on the development of federal constitutional law, with the result that current sources on state law and development tend to be dated and of limited use fulness.

Two especially fine works portray at the national level the major actors in church-state cases. 10 Separationist and accommodationist groups there have become so aware of each other and so formalized that their strategies and conflicts have been described as an involved minuet. Frank Sorauf and Richard Morgan have each carefully studied the litigants and their strategies, as carefully orchestrated as that of the plaintiffs in the desegration cases which led to Brown $v$ Board of Education.11 At the state level, however, there exist more actors and less coordination. Indeed chaos is not an inapt term. Local chapters of national groups such as the American Civil Liberties Union (ACLU), local Catholic bishops and schools, local public school boards and private citizens act with both greater autonomy and greater irregularity. They will often have determined the facts or the agenda before the national protagonists can intervene. Thus some awareness of the national actors is necessary but not sufficient for understanding developments within a state.

In 1955 Orville Zabel published his centennary God and Caesar in Nebraska-Church and State 1854-1954. This excellent state history examines the development of church-state relations in Nebraska and contrasts that development with laws and practices elsewhere.

It is appropriate for a comparable study to be done today, both because 
so much change has occurred since 1955 and because the reversion to state constitutions has created a need for good state histories on critical constitutional subjects such as religion. Some members of the Oregon Supreme Court, and some Oregon scholars, have been seeking for over two decades to interpret the Oregon constitutional provisions on religion in a more strict and more separationist manner than the federal First Amendment. In so doing, they have appealed--the author believes incorrectly--to Oregon history, selecting, in the manner of lawyers, only those words or incidents which support their views.

This thesis seeks to provide a firm base of information, so that Oregon scholars and lawyers will have a fuller account from which to draw. To make the work more useful, its bibliography includes annotated lists of Oregon cases, laws, attorney general opinions, and law review articles. The author has written at length on the Oregon School Bill in his 1984 thesis, The Oregon School Bill of 1922--Reevaluation, 12 to which readers are directed for a fuller account and documentation than occurs here.

Historians writing on Oregon have emphasized the persistence of racial and religious bigotry from its earliest days to the present. However, they have rarely focused on religious or legal matters. When they have done so, they have usually included significant errors of fact or perspective. This work, by joining legal, historical and religious perspectives, seeks to provide a corrective resource. It also identifies the unrepresentative nature of reported legal cases, and emphasizes the need to review the practices of the people, which may not conform to the supposed legal norms. Some writers speak of American church-state relations as a de facto establishment of Protestant Christianity.13 As separationist or secular visions of the preferred relationship have come to predominate, there has developed a cognitive 
dissonance, a gap between the assertions by our courts as to what the law is or should be, and the practices of the people and many of their local institutions. It is a legal, a policy and a historical question just how much weight should be accorded to those persistent practices which court decisions have been slow to eliminate. A very few cases, using the method the author believes most appropriate, have assayed the practices of the people and their characteristic representatives as the best guide to what the law should be.14

Lawyers know little of history and usually misuse it. 15 Historians know too little of law, and often misunderstand or misrepresent legal developments. Writers on religion of ten know little of either law or history save as it affects their sect. Historians generally give too little attention to religion. 16

By using the Oregon example, the author hopes to present the factors and methods of analysis which he believes show the full extent of church-state relations in all of their complexity. The method chosen is thematic, and necessarily involves some duplication, but references have been streamlined to facilitate reading and cross-reference.

The author has a Roman Catholic upbringing, has served with boards and committees of the ACLU since the 1960s, and describes himself as belonging to the free exercise rather than the establishment, or rather anti-establishment, wing of the ACLU. He is also a strong believer in judicial restraint and that judges are to interpret and enforce laws but not to make them. This perennial conflict assumes a different label for each generation. These biases should be evident in the text, but readers who are unaware of these distinctions may find early mention of them helpful. In terms of the religion cases, Richard Morris characterizes these variations as separationist or accommodationist, but these terms merely describe directions on a continuum which some scholars, such as Howe, think may be circular. 17 
For purposes of this thesis, it seems not necessary to define religion, although such definitions are not unimportant to the subjects of this study. The courts, under the terms of equality of treatment and non-establishment, have been progressively widening the acceptable meaning of religion until it has become so broad as almost to lose meaning. 19 Present definitions would prove unrecognizable to the founders of the state. Problems of definition have mostly proved unimportant in Oregon history. What has proved important is the distinction between denominational or sectarian religion, as opposed to non-denominational religion or religion as an integrative force (civil religion). Courts have routinely denied the former either funding or a role in state institutions, while retaining a place of honor for the latter.

The sequence in this thesis is largely chronological across a range of important themes. Because state courts and other state personnel have of ten acted without apparent reflection, without awareness or consideration of state and national history, and at cross-purposes, some sections read unevenly. That style reflects the content, where a smooth narrative account would not do justice to the discontinuity of the events. Religious historian Martin Marty has described American religious history as a "chaos" or accumulation of "concurrent tumults",20 and suggested that a proper history can only proceed by first honestly naming its subject as chaos. Other sections such as the overview on constitutional development and the period of the Oregon School Bill lend themselves to a more traditional-appearing historical account.

An attempt is made at the beginning of each chapter to set the background for its subjects and themes. It is critical to reflect that each choice might have been different. Decade by decade, American (not to speak of foreign) examples presented a wide range of selections of differing methods of management of each area of church-state relations. 
The range of choice remains wide even in the Oregon of the 1980s. Oregon's choices--how to shape church incorporations, how to limit church ownership of property, whether to fund church personnel or institutions, the manner and extent of tax exemptions--were not predetermined and could have been resolved in a number of other ways. This text seeks to show first what choices were made in Oregon, and then to provide some insight into them.

Oregon is considered by its leading historians to be affected periodically by religious and racial prejudice. The salient example is the period of the $\mathrm{Ku} \mathrm{Klux} \mathrm{Klan}$ in the 1920s and the passage of the Oregon School Bill. The management of church-state relations has generated a larger number of cases and controversies than most lawyers and historians realize. Using techniques and insights employed by lawyer-historians such as Zabel and Howe, this thesis examines in detail, case by case and sect by sect, the development of principles of church-state relations in Oregon. Zabel, in his history of Nebraska's church-state development, had opined that Nebraska's history was that of the nation writ small. He concluded that American jurisdictions had essentially followed a common path. The Oregon example suggests otherwise. Howe has demonstrated the wide variety the forms of church-state management took in American jurisdictions and suggested a rationale for some convergence among the states in form. However, what each demonstrates upon examination is how each jurisdiction had a wide range of choice and that wide experimentation was and continues, in spite of the homogenizing pressures of the federal courts, to be the rule.

Howe predicted that the concept of equality of treatment, which he saw as the dominant theme of 20 th century law and politics, would have the effect of so broadening the definitions of religious groups as eventually to remove the protections afforded them when the definition was more narrow. 
That prediction is proving true.

Finally, in recent years the United States Supreme Court, reversing a pattern of at least thirty years, has begun to defer again to the states in such constitutional areas as religion. States, Oregon being a leading example, have responded with increasingly independent interpretations of their own constitutions in order either to avoid federal dictation or to accept its invitation to independence. This reversion to state court law-making has created a need for detailed state histories of religion and law.

This thesis presents the major themes, events and persons of Oregon's legal-religious history. It examines education, enforcement of morality, taxation and exemption, the treatment of minority religious groups, and the rise of professional interest groups. Legal sources such as court decisions, attorney general opinions and statutes are assembled, assessed and annotated. Church histories, theses on Oregon's religious groups, biographies and memoirs of leading actors are carefully reviewed. Special attention is given to Oregon's constitutional development on religion and to the Oregon School Bill, which set a national precedent for religious liberty while simultaneously expanding the federal role.

A combination of factors--the expansion of the roles of state and federal governments, the rise in taxation attendant upon that expansion, religious (especially anti-Catholic) prejudice, the progressive secularization of public fora and of legal rationales, the impulse to equalize treatment of religious and non-religious groups--have all converged in Oregon. That combination has left the law, in appearance and in fact, not only unfriendly but in many areas seemingly on the attack against religion. Because U.S. Supreme Court decisions establish a minimum to which states must adhere, state independence can only be directed toward further restriction of 
religion. 21

Whatever the reality, state institutions will therefore appear to be more unfriendly than the federal. The general animus against special deference to religious groups overarches other factors and contributes to the special actions which, when taken against this church or that, seem to display only special bias. While anti-Catholic prejudice, e.g., is real and important, it is not sufficient explanation for the state's persistent extreme separationist trend.

A correct reading of the history of Oregon's constitutional foundations and of the practices of its people should result in a more accommodationist attitude on the part of Oregon's legal entities. 


\section{I . PROLOGUe}

A perennial problem in Western culture has been the management of relations between church and state. The Christian West, with the inherent dualism of its loyalties to earthly and heavenly kingdoms, has wrestled for centuries with the problems of dominance, separation and accommodation. 22 At times the solution has appeared simple, such as when the Roman Catholic Church ruled church and state, or when each principality followed the rule of cujus regio, ejus religio.

Such orthodoxies, eternal or momentary, never resolved the problem of the correct relationship. Indeed such orthodoxies never entirely held sway even in their own times. Both academic and very real dissent were always present. Succeeding ages, or succeeding weeks, would raise it anew. The movements of rationalism, enlightenment, Protestantism and democracy only presented in new form the questions which previous ages had addressed in terms of the proper sphere of Pope and Emperor. With the onset of the Reformation, men's consciences now sought new mediators between God and man and between man and man, or would brook no mediation. The problem of intolerance for the church or particular churches became more intense.

In the United States, the colonies came to have different methods of accommodation of church and state. The firm orthodoxy of Plymouth Colony led to the partial tolerance of Rhode Island. Accidents of friendship and loyalty induced the grants of Pennsylvania and Maryland as temporary havens of tolerance for Quakers, Catholics, and others. When the United States was formed, there was thus no one model of how church, state, and the individual should interact. It was this very diversity of solutions which was part of the states' firm resistance to the idea that a federal government should have any powers in this and like areas. 
The colonies, each jealous of its hard-won liberties and wary of establishments, whether of Church or Crown, wrote into their Constitution a rule that the new national government would have no role in church-state relations. Although many believed that, in a government of limited power, the federal government could not act at all where not expressly authorized, others thought a Bill of Rights necessary expressly to ensure non-interference. The First Amendment, ratified in 1791, succinctly stated: "Congress shall make no law respecting an establishment of religion, or prohibiting the free exercise thereof."

The states, each in its own wisdom, were left to determine the arrangements which best suited them. Some, such as Virginia, tended from the beginning to strong separation. Others such as Massachusetts continued to have established churches into the 1840s. New Hampshire even into the 1880 s still restricted to Protestants the right to serve as Governor or in the legislature. The leading legal scholars of the 19th century, James Kent, Joseph Story and Thomas Cooley, emphasized not only that the federal government could not intervene in state religious matters, but described the common law as Christian in nature.

At any given time, the states presented an array of relations. Of course, in those days the U.S. was deemed to be a Christian nation. 23 The founders' pronouncements and our documents of birth are replete with statements of dependence upon the Almighty. To many statesmen and scholars, the roots of both democracy and liberty were found in Protestantism. However establishments official and unofficial, after the Revolution as before, presented the problem of how the state should choose, if at all, among churches. The exiled Puritan came to contend with Anabaptist and Quaker, and met their threat by exile or even hanging. The new orthodoxy of Roger 
Williams' Rhode Island, in spite of the eloquent language of The Bloudy Tenent, had little room for other dissenters. After the Revolution, the established Church of England was rejected, only to be replaced with stateestablished churches which continued to tax and discipline all citizens.

Perry Miller well points out that only in the 1950 s was Roger Williams "discovered" as a prophet of extreme separation of church and state. To his contemporaries, he was no such thing.

The Blaine Amendment, introduced by the Speaker of the House, James G. Blaine in 1875 during the Grant Administration, sought to apply the federal First Amendment to the states, but failed of passage. It continued to be introduced into the 1940 s, over 20 times in all. Until the 1930 s there was no acceptance of a federal role in church-state relations.

In the 1780s, questions of congregational versus episcopal policy began to break down the state-established churches. Over time political pressures, generated by increasing numbers of adherents of non-established churches, led to resolution or laws which effectively congregationalized 24 existing orthodoxies. Mark DeWolf Howe well analyses this period of change in The Garden and the Wilderness. Congregationalism was more in tune with American ideals of freedom of conscience and government by the consent of the governed. 25

The politics and wars of Catholic France with England in the early 1800 's and Protestant atavistic fears of the Pope as anti-Christ confirmed the drive toward individual and congregational independence. However, the tendency was not to remove the church-state connections, but progressively to non-denominationalize them. A Christian nation still, the U.S. found itself in the Horace Mann compromise of 1848 where the King James Bible would be read in the public schools, but there would be no proselytising for particular 
sects.

Oregon was first settled and came into being as a political entity during this period. Governed by nominally Church of England Great Britain, it was actually largely manned by Presbyterian Scots managers and French Catholic Metis trappers. The American settlers were accompanied by Methodist and later Presbyterian ministers such as Jason Lee and Marcus Whitman. The uneasy accommodation of nations was paralleled by an uneasy accommodation of religious practices. Protestant and Catholic competed, first and always for souls and then for the land and its governance. The Americans, to secure votes, were at first open to the French trappers and British settlers. The British, seeing the potential and then the reality of American immigration and dominance, were generous and accommodating of the Methodist pioneers. But behind the surface cooperation, there was a struggle to save the Oregon country for the United States and from the Catholics. The Protestant missionaries and settlers thus set from the very beginning an anti-Catholic tone and enforced an anti-Catholic reality. The history of Oregon begins with religious conflict. 


\section{THE FEDERAL BACKGROUND}

Federal law has been operative in Oregon since Territorial Days. State law cannot be understood without a firm sense of the federal presence.

When Oregon was a Territory, federal law applied, although the Territorial legislature and officers were its erratic instruments. The peaceful resolution of both the Oregon question and the boundary question had been quiet triumphs of diplomacy, especially in the face of provocations such as the Whitman Massacre Myth. Such chicanery as that which deprived Hudson's Bay factor John McLoughlin of his Oregon City land claim had a religious aspect, but can not be isolated as religious.

The troubling question of Oregon's early days was that of the Indian missions and schools. Under the federal reservation system, these were assigned to Protestant or Catholic, often without respect for the wishes of the Indians or for who had previously operated the mission. Federal and territorial law also provided that missions should be alloted a certain amount of land, which led to disputes among missions and churches about who was entitled to which area. In The Dalles, although the Catholics had been operating the mission since the Methodists pulled out during the Cayuse War period, the Methodists unsuccessfully sought to stake a claim. ${ }^{26}$

In 1875, under the anti-Catholic administration of President Ulysses S. Grant, his surrogate, then representative James Blaine, introduced into Congress the "Blaine Amendment", which sought to impose upon all of the States the equivalent of the federal First Amendment and to prevent aid to religious schools. That amendment passed both House and Senate by majorities, but failed to obtain the two thirds Senate vote needed for passage. Blaine later became tainted by association with the phrase of "Rum, Romanism, and Rebellion" which marked his image in history as anti-Catholic 
and thus doomed his own presidential aspirations. ${ }^{27}$

The second federal responsibility which dominated the late 1800 s and continued to dominate until the 1920 s was that of Immigration. The 1840 s and post-Civil War period brought the Catholic Irish and the Catholic Eastern and Southern Europeans into the States in immense numbers. Resultant periods of intense nativism gave rise to the Know-Nothing Party in the 1850s, and the American Protective Association in the 1890s. Each had but brief impact and little membership in Oregon. The Spanish-American War of 1901 was seen by many as a war against Catholicism, to free Cuba and the Philippines from the rule of the Pope. The hyper-patriotic activity of World War I and its aftermath again accented feeling against those who retained foreign ways or rule. The Catholics were especially subject to this wave of feeling, because the Pope was seen as a foreign and anti-American ruler.

Donald Kinzer well analyses the American Protective Association, 28 and John Higham gives a splendid view of the whole process of nativism into the 1920s.29 Within Oregon, Charles Carey and Priscilla Knuth give detailed accounts of the APA and of the factors and groups which rose periodically against Catholies and other foreigners. 30

The Know-Nothing Party in Oregon was a short-lived phenomenon. Although a separate party, its members were centered in the Whig Party of that day. When Asahel Bush, editor of the Salem Statesman, obtained a list of its members and threatened to publish the list if they did not withdraw, the Party was dead. 31

The American Protective Association hardly fared better. At best it had a few members in Oregon. Like the Klan of the 1920s, it inflated its membership figures and appeared more formidable for a brief period than it proved in fact to be. 32 
However, the loyalties, fears, and views of Protestantism and Americanism which motivated those who joined, remained powerful forces in Oregon life. "Escaped nuns" were a staple on the Oregon lecture circuit in the period. The Tale of Maria Monk, the equivalent to the Catholics of what the Protocols of the Elders of Zion was to the Jews, had a continual circulation.33 Circulation of one such tale led to a successful state criminal prosecution for malicious libel in the 1905 Hosmer case. The development of the patriotic societies, such as the Orange lodges and the Knights of Pythias, and of the Masons, all sustained a view of the Catholic Church as inimical to American ways and provided a firm background for periodic eruptions of prejudice.

Once Oregon became a state in 1859, under the views of the federal First Amendment then prevailing, the United States was thought to have no role on religion within the state. When cases were brought, even as late as Brunswick in 1916, the federal court merely recited that the federal Constitution left such matters to the states.

It is worthy of note that one of the major authors of the 14th Amendment, which the U.S. Supreme Court has held to impose the First Amendment upon the States, was George Williams, 34 Oregon's U.S. Senator from 1865-1871, who as Republican U.S. Attorney General in 1875 was one of the supporters of the Blaine Amendment. The evidence is unsatisfying that the authors or Congresses of the time believed by passage of the 14th Amendment that they were affecting States' rights in the area of religion. Indeed, the Blaine Amendment in one form or another continued to be introduced into the 1940 s, Congress after Congress, showing by the attempt the prevailing belief that the First Amendment did not apply to the States. When the Oregon School Bill, which appeared 35 to outlaw private and 
parochial schools, was passed by initiative in 1922, the Catholics at first saw no role for the federal courts or government in overturning it. However, when the U.S Supreme Court in Meyer $v$ Nebraska,36 decided in 1924, announced that the federal Constitution would now prohibit a state from criminally punishing a school teacher who taught in German, this precedent led the Catholics and the Hill Academy to file in federal Court under the federal Constitution. In its decision in 1925, in Pierce $v$ Society of Sisters, the U.S. Supreme Court firmly announced that henceforth parental rights to education of children were enshrined in the federal Constitution, that states could regulate but not eliminate these rights. This charter for private and parochial schools has continued to serve as a firm shield for them from too aggressive state regulation. 37

In the same period, the National Immigration Act of 1924 was passed, which firmly placed a lid on immigration from Eastern and Southern Europe by imposing national origin quotas. This lid, plus the good times of the period, satisfied and thus dampened the strong nativistic impulses of the immediate post-War period.

Prohibition, made part of the national Constitution in 1919,38 created a federal presence throughout Oregon and the rest of the country. Its imposition, both then and during the agitations of the Women's Christian Temperance Union Days of the previous century, had anti-Catholic overtones, and were strongly supported by the Protestant Churches, especially the Methodists and Quakers. Indeed, the Oregon legislature considered in the 1923 session outlawing sacramental wine. The forces behind Prohibition were those of respectable Protestantism. At the 1924 Nominating Convention of the Democratic Party, the Democrats were not able to adopt a resolution repudiating the $\mathrm{Ku}$ Klux Klan, which was seen by nearly all as prejudiced 
against Catholics and Jews. Al Smith, both as Governor of New York and as Presidential candidate, was seen as tainted by his Catholicism and by his lax enforcement of the Prohibition laws.

Under the Roosevelt administration, the federal government began to expand its role into areas previously the realm of the states. Federal laws and regulations followed the federal dollars. Even if the U.S. Supreme Court had not begun in the 1940s to interpret the federal First Amendment as now applying to the States, the same effect was being achieved through federal programs and dollars. In 1940, the U.S. Supreme Court decided the first Jehovah's Witnesses' cases concerning flag salutes and pamphleteering on the streets, and so established a federal law and presence in the area of religion. This was extended with the aid-to-parochial-schools decisions beginning in 1947, the Bible-reading decisions of the early 1960s, and accelerated in the last two decades. Indeed, the federal presence became so great that a generation of lawyers and judges came to forget the primary and historical role of their own state Constitutions. ${ }^{39}$ From 1960 to the 1980 , lawyers and organizations such as the American Civil Liberties Union would invariably file in federal courts. Only in the 1980s, as the U.S. Supreme Court began taking more accommodationist positions, did a reverse trend set in. ${ }^{40}$

In 1944, in the case of Thornton $v$ City of Portland, the Oregon Supreme Court declared that, although they were couched in different words, the religion clauses of the Oregon and federal Constitutions had the same meaning. This principle was reaffirmed time after time (with two temporary exceptions: in the Dickman case and in the second decision of the Eugene Cross Case trilogy). However, in 1985 the Court, now under the dominance of liberal constructionists, reinterpreted the Oregon Constitution more narrowly than the federal in the Salem Academy case. 
Although the most current analytical method 41 focuses first on Oregon law, the federal law still sets minimum standards. The states, such as Oregon, can be more restrictive of religious establishment, but they cannot be less. They can provide more religious freedom, but they cannot provide less than the federal law requires. The federal presence is still substantial.

In 1964, the federal government passed the Civil Rights Act, 42 which prohibited discrimination on the basis of religion and creed, as well as race and color. An Executive Order, 43 introduced the same year, prohibited such discrimination for all federal contractors. The Elementary and Secondary Education Act of 1965 similarly provided for massive aid to schools, and included provision of aid to parochial schools. These provisions, and others like them, necessarily affected Oregon as well, though perhaps less than other states to the extent that Oregon had fewer federal bases and major contracts. Oregon does however have its public schools, the Bureau of Land Management and Forest Service, the Bonneville Power Administration, and a substantial federal presence, which set standards for the state, and supplanted it in some areas, because of the effectiveness of the federal remedies.

Indeed, in 1985 , the federal Congress passed a law which required all schools receiving federal aid or having federal contracts to provide equal access to religious groups and students with other groups. 44 This law has required districts to adopt or consider adopting rules to implement. The moving force behind this law was Oregon's Senator Mark O. Hatfield, who has stressed that its intent is to protect religious liberty.

The federal law is now a dominant and omnipresent factor in matters of religion and law within Oregon. This is a radical change from the first century of Oregon's history. Today's renewed reliance upon the Oregon constitution still recognizes that the expanded federal role sets minimal 
standards. Thus the federal law, whether overtly or not, will be carefully analysed in each case. The range of choice for the states has been progressively limited. As Zabel says, such expansion of federal jurisdiction reduces "religious freedom by imposing national uniformity at the expense of local solutions...." 45 


\section{OREGON CONSTITUTIONAL DEVELOPMENT}

1857...The Oregon constitution is adopted. At the Convention, there is a September afternoon's discussion on whether to pay for chaplains in the legislature... And then, 105 years of silence.

Only in 1962 does the Oregon Supreme Court decide to apply Article I, Section 5 and disallow free textbooks to parochial school students based upon a prohibition "found" in the Oregon Constitution. That decision, Dickman $v$ School District 62C, has but one paragraph devoted to history. That paragraph says in full:

The historical setting in which constitutional provisions such as Article I, Section 5 were written and the factors which prompted their adoption have been thoroughly explained elsewhere; it is not necessary, therefore, to repeat those observations here. 46

The sources cited have nothing to do with Oregon, save only Charles Carey's record on the Oregon Constitutional Convention of 1857.

On the federal level, the U.S. Constitution was approved in $1787 \ldots$ And then, 160 years of silence. Only in 1948 did the U.S. Supreme Court find that the First Amendment religion clauses apply to the States, in spite of their express words that "Congress" shall make no laws... That decision, and its successors, while they refer to history, are also remarkably devoid of it. They are criticized uniformly by historians, even by those who approve of the caseholdings.

How is it that in the United States and in Oregon, where the written Constitutions are our Bibles and we require that judges explain and justify their decisions, that major constitutional changes suddenly occurred, after over a century, with no historical justification and indeed with no history? What 
happened in Oregon?

The fact is that there is a history of religion and law in Oregon. If that history never appeared in the law books, it is not because it did not exist. In our government, history constitutes the records of our fourth branch of government--the people themselves, in whom are reserved all powers. However, the common practices and shared beliefs of a religious people were not thought to belong in the courts, so long as the government did not seek to suppress religion. Oregon has a long history, which its early courts did not find necessary and its later courts have not seen fit, to examine.

Legal historians have long faulted lawyers and courts. They point out that constitutional cases tend to be misrepresentative. They present, not what usually happens, but the unusual. Courts, which rely upon unusual cases as their sole or primary source of guidance, are systematically misled in their use of history. 48 The narrow methods of courts in handling rules of evidence are unsuited to insightful examination of broad themes and subjects, and can be too twisted by the partisan pressures of the adversary system to allow dispessionate search for truth. Legal truth is managed truth. Moreover, courts are reluctant and often unable to go back and correct later-discovered errors. A decision, once made, acquires a life of its own, even if originally wrongly decided.

In the area of religion, the history as recounted by the courts has been outstandingly poor. The federal cases, whatever one thinks of them as policy, ignore or misrepresent the history and intent of the First Amendment. Historians of all persuasions are remarkably uniform and severe in their criticism, from Edward Corwin to Leonard Levy, from Paul Murphy to Michael Malbin. The innovative federal changes are so devoid of accurate history as to have given birth to Corwin's riposte: "Undoubtedly the Court has the right 
to make history....; but it has no right to remake it." 44

The Oregon Country was settled by the Hudson's Bay Company, which employed Catholic French and Metis trappers. The first American settlers were missionary Protestants, largely Methodist. Catholic and Protestant began to compete for Indian souls: The infamous Whitman Massacre in 1847, when Marcus Whitman and many of his company were killed by Cayuse Indians, was used by some Protestants to seek to discredit Catholics. Some blamed the Catholics, and indeed there was an attempt to pass a law expelling Catholic priests from the Oregon Territory.50 When Chief Factor John McLoughlin of the Bay Company reconverted to Catholicism, the American sentiment against him took on anti-religious overtones as well.

The first organized governments of the Oregon Country were deeply religious and friendly to religion. Indeed, the "Mission Party" retained control for a number of years. The Organic laws of both 1843 and 1845 included verbatim the famous words of the original Northwest Ordinance:

Religion, morality and knowledge being necessary to good government and the happiness of mankind, schools and the means of education shall forever be encouraged. 51

In the 1700 s and 1800 s, nearly all Americans believed that religion and government were inseparable, that good government must be firmly grounded in religious belief. From the earliest times, we have merged the Pilgrim Fathers with the Founding Fathers, with our "city on the hill" being based upon both Bible and Constitution. The federal Constitution had prohibited the federal government from interfering in religion in the States. But within the States there were in post-Constitutional days several established churches. A gradual evolution occured as the character of the inhabitants changed, more and more respecting individual beliefs, but also retaining religious practices in schools, courts, legislatures, and throughout 
government. State governments evolved away from establishment. They fiercely rejected imposition of particular religions on the unwilling, but also firmly established prayer, Bible reading, chaplains, and religious observances in the secular part of life. Leading 19th century Constitutional scholars, such as Thomas Cooley, James Kent, and Joseph Story, found that Christianity was an inseparable part of the common law and compatible with the federal constitutional system.

When, in 1857 , Oregonians eame together to draft a Constitution, 52 they established a committee to make a Bill of Rights. That committee, using the Constitution of Indiana as a model, $\mathbf{5 3}$ presented what became Article 1 of the Constitution, with Sections 2 through 7 dealing with religious belief. These provided: that all men were free in religious belief, that no law should interfere in free exercise of religious belief and rights of conscience, that no religious test should be required for office, that no person should be incompetent as a witness or be questioned in court on his religious belief, that oaths should be in the form most consistent with a person's beliefs and, in Section 5, that no money should be drawn from the Treasury for the benefit of any religious or theological institution, or appropriated for payment of any religious services in the legislature. As originally drafted, this last section would have prohibited compensation for any religious services, but in final form the prohibition was significantly narrowed. The committee and Convention declined to adopt the anti-establishment section of the Indiana Constitution. 54

Only Section 5 occasioned debate. Hector Campbell moved to strike out the provision preventing employment of a chaplain by the legislature. After long discussion, his motion passed.

The original section read: 
No money shall be drawn from the treasury for the compensation of any religious services, or for the benefit of any theological institution. $\mathbf{5 5}$

After Campbell moved to strike out so much of it as would prevent the employment of a chaplain in the legislature, the text was changed to read:

No money shall be drawn from the state treasury for the benefit of any religious or theological institution. 56

This was adopted by a vote of 24 to 16 . A motion by George Williams, to prevent payment for religious services in either house of the legislative assembly was defeated at this point. However, when Williams again presented his amendment to the Convention in September, it passed by a vote of 26-21, so that the final version, as engrossed, added to the above words:

Nor shall any money be appropriated for the payment of any religious services, in either house of the legislative assembly.

The original section when first introduced was labelled as Section 6, although it became Section 5 in the final version. The original section 5 , although approved and passed, unaccountably disappeared from the final version. This section, a non-establishment or non-preferment clause, read as follows:

No law shall give preference to any creed, religious society, or mode of worship; and no man shall be compelled to at tend, erect or support any place of worship, or to maintain any ministry without his consent.

Because the legislature did not approve a verbatim transcript of its proceedings, no account appears to exist which explains this deletion. 57

The most eloquent and substantial statement was made by the President of the Convention, Judge Matthew Deady, later Oregon's federal judge for over forty years. Deady asserted as the reason that the legislature should not pay to prefer one religion, that this would necessarily tax all people to support one religion. 
What is the theory of our government upon this subject? It is that the government shall be separated from the churches, and the maintenance and administration of religion; that religious duties shall be no function of government. And why? Because the country contains persons of all religious denominations, as well as non-believers, and if you have religious services carried on and paid for by the government, you necessarily tax all people to support some one religion, let their sentiments be what they may. 58

But Deady further asserted that he would vote to invite a chaplain to officiate before the legislature. It was not the involvement, it was the payment necessarily coerced from dissidents, to which he objected.

Interestingly (and unnoticed by the courts since), when the Convention later addressed education, Judge Deady, the "Oregon Justinian" and father of the University of Oregon, spoke again with eloquence. He moved to strike out the section providing for the state university, fearing that it would be "really, though not nominally, sectarian" as it was in Indiana. Judge Deady thought:

Education should be under the direction of the various religious denominations of the country, and parents could send children in accordance with their sectarian bias. And if the state appropriated a school fund, let it be drawn by the various sectarian schools, in proportion to the number of scholars they had, and let those of no religious profession draw their proportion. 59

His motion carried. This expressed a friendliness to religion in education. It also, perhaps, made a distinction between monies drawn from the Treasury by taxation, necessarily also from dissenters, and that drawn for the benefit of all groups from the common school fund. Deady believed both that there was no evil if all could draw, and that was especially true of funds not derived from direct taxation which therefore did not require dissenters to pay.

Both the Territorial and new State legislatures remained friendly to 
religion. One law allowed a mission to hold a township (23,040 acres). In the early days, until into the 1880 s, most schools were private sectarian schools, and some were funded from local taxes. Religious leaders taught in them, with prayer and the Bible as their staples, supplemented by the piety of books such as the McGuffey Readers. 60 Perusal of articles in the Oregon Historical Quarterly shows over and again the permeation of religious observances in the schools far into the 20th Century. Several theses from the University of Oregon examine religion in Oregon public life and schools. Robert Woodward, writing in 1963 on Education in Oregon in the Progressive Era, and Wallace Farnham, writing in 1965 on Religious Influences on Life and Thought in Jackson County: 1860-1891, make clear what no one has disputed: that church and religion in the public school and public life were common and thought to be acceptable by nearly all. As historians such as David Tyack have noted, 61 missionaries were a driving force behind the development of education in Oregon, and their influence pervaded schools public and private. When Catholics later objected to Bible reading in the public schools, they sought not to exclude it, but to be able to read their own Bible. Prior to 1922, Catholic nuns in religious garb taught in several public school districts and were paid from public funds. 62

The main controversies about religion in Oregon in the 1800 s involved politics or federal law, especially the perennial question of which religious groups were to be assigned the Indian schools. The anti-Catholic Know Nothing Party made a brief appearance, but was shamed into oblivion by threat of exposure of its members. The American Protective Association also made an appearance in Oregon, with anti-Catholicism as one of its themes. It was stimulated by hard times, and by controversies about Papal condemnation of secret societies (such as Masons, Knights of Pythias, Knights of Labor), 
indignation over Papal condemnations of Americanism, Modernism, and Masonry, the declaration of Papal infallibility, and about turn-of-the-century arrangements in New York and Massachusetts under which Catholics were allowed to be paid teachers in public schools. The Temperance Movement in Oregon also had religious overtones. But none of these currents required formal action by the government of Oregon directed to religion as such. ${ }^{63}$ Decade by decade after 1875 , Oregon and the U.S. were faced with the Blaine Amendment, which sought to impose the federal First Amendment upon the States, and perennially rejected such imposition.

In the $1900 \mathrm{~s}$, prayer and Bible-reading remained common in the public schools of Oregon, as evidenced by general accounts and occasional articles of protest. 64 World War I brought a resurgence of patriotism, and a resurgence of religion, into public life. Financial pressures and scarcity of teachers led to religious personnel teaching in public schools wearing religious garb, especially in rural areas where nuns were the only teachers. The fury of war and its aftermath, the concern about communists and immigration restriction (later largely satisfied by the post-War federal restrictions on new immigration), stimulated the rise in Oregon of the second $\mathrm{Ku}$ Klux Klan from 1921 to 1925.65

In 1922, seemingly from nowhere, the Klan dramatically appeared in Oregon, advocating a pure Protestant America. It supported laws, passed in 1922-1923, which prohibited religious garb in public schools, and would have prohibited the existence of private and parochial schools. It would have required that all schools be conducted in English. The Compulsory School Bill would have harmed especially Catholic and Lutheran schools.

In an impressive one-day campaign, the Masons, the true and effective force behind the School Bill, gathered enough signatures to place an 
initiative to outlaw private schools on the ballot. Oregon became a focus of national attention, some writers claiming the state was controlled by the Klan. Governor Walter Pierce and others were accused of being Klan members. A lawsuit was soon brought by Hill Academy and the Catholic Society of Sisters in the federal court, which held that the law violated the federal Constitution's contract rights. Because the federal First Amendment did not apply to the States, it was not invoked. (It is also remarkable that Section 5 was not invoked, or deemed sufficient to prohibit religious garb in the schools, evidencing what people thought Section 5 meant). Governor Pierce, supported by the Masons (who still believe they were right), 66 appealed to the U.S. Supreme Court which, in 1925, firmly rejected the law. That landmark case, Pierce $v$ Society of Sisters, established for the whole country the rights of parents to control the education of their children. Although some historians, such as Father Lawrence Saalfeld, in his recently republished Forces of Prejudice in Oregon 1922-1925, have described this period as one of prejudice and Klan-domination, later accounts present a more balanced picture, showing the influence of Progressive and Enlightenment forces, which considered the Catholic Church to be anti-democratic, anti-American and superstitious, and which wanted to shape the new society through the vehicle of the public common schools which all must attend. ${ }^{67}$

From the 1800 s into the 1920 s, "escaped nuns" were common on the lecture circuit in Oregon. ${ }^{68}$ Malcolm Clark, in "The Bigot Disclosed: 90 years of Nativism", discusses ${ }^{69}$ another secret order, the Guardians of Liberty, whose one claim to fame was actually to have produced an "escaped nun", Mary Losenan, who told of kidnap, orgies and infanticide, placing part of her captivity in the convent at Mt. Angel. When J.E. Hosmer of the Silverton Journal published her accounts in both press and pamphlet form, the convent 
sued for publishing a malicious libel. Convicted, Hosmer was sentenced to a short prison term.70 Friendly to religion in many senses, the state's people, as noted by all of its historians, 71 maintained a continual theme of racial and religious prejudice against certain groups. Al Smith, Catholic and Democratic Party candidate for President, campaigned in 1924 and 1928, with religion and Americanism among the major themes. The 1924 Democratic Convention declined publicly to reject the Klan, even though the Klan itself was soon to be dead, "killed by its own hand",72 by 1925 .

In the 1920s came the worst days of Prohibition, seen by many as having religious overtones, as Progressives and Fundamentalists joined forces against Catholics, and law enforcement took a holiday into the 1930s. The American Civil Liberties Union arrived in Oregon. The clash of Darrow and Bryan over evolution in Tennessee reverberated in Oregon. The 1930s saw the arrival of the Jehovah's Witnesses, pacifists and persistent proselytizers, in the federal courts.

In 1944, the Oregon Supreme Court, in Thornton v Portland, said that Oregon's religion clauses should be interpreted in the same way as the first Amendment, a decision justified by neither logic nor history. Thorton attached Oregon's constitution not to a fixed star but to a comet--of varying path, direction and intensity. The case itself involved whether the State could prohibit a Jehovah's Witness from using his children to solicit on the streets. Oregon followed a U.S. Supreme Court decision, Prince v Massachusetts, which supported the state.

In the 1940s, Oregon and other states approved laws allowing released time from schools for religious instruction. Although such laws were approved by the Attorney General and later by state and federal courts, school funding cases began to generate immense controversy. ACLU and other interest 
groups began to press the federal courts for removal of religion from schools and public life. In 1947, the U.S. Supreme Court first struck down a state program of aid to religion with the First Amendment. Federal decisions began to produce changes in long-standing practices in Oregon. In 1952 an Attorney General Opinion disapproved of Bible study and religious education in public schools.73 The practices, however, continued and that opinion is evidence of their continuance, as laws are made when there are problems.

In 1961 and 1962, an Oregon Constitutional Revision Commission proposed changes in the Oregon Constitution. After immense objection form religious groups, it declined to recommend an ACLU proposal that "The public schools shall be forever free from sectarian control or influence, and no religious instruction, exercise or worship shall be part of the curriculum of any public school." The ACLU had noted that "most states have specific provisions against religious instruction in the public schools," but Oregon did not. The Commission proposed, as if in rebuttal to Judge Deady, to change the Article I, Section 5 words: "No money shall be drawn from the Treasury..." to "No public money shall be used...".74 The change was not approved, but in 1962 the Oregon Supreme Court decided the case of Dickman v School District 62C. The Oregon legislature had passed a law which provided free textbooks to all Oregon students (permissable under federal law), Including those in parochial schools. However the Oregon Supreme Court, in an opinion by Justice Kenneth O'Connell (one of the members of the Revision Commission), interpreted Section 5 as if it said "No public money..." and held that nothing, neither money or services, could be provided by the State if it benefited a religious group. Normally language in a State Constitution which limits the people's powers is narrowly interpreted, but not in this case. Oregon's friendliness to religion (i.e. to Protestant or civic religion) was, at 
one bold stroke, officially gone.

In later years, Justice $\mathrm{O}^{\prime}$ Connell would be celebrated (by such as ACLU) for his activist interpretations of the Oregon Constitution.75 In a 1984 ceremony honoring Judge O'Connell, Judge Alfred Goodwin, another activist and member of the Revision Commission, amusingly mispoke himself and, purporting to quote Section 5, instead recited the failed-in-vote but successful-in-court "no public money" interpretation.76 As Judge Hans Linde has said and written: When I was on the Revision Commission, we sought to make changes in the Constitution. When I was appointed to the Court, I found that the changes we wanted had been there all along.

One might have thought, after Dickman, that a clear course was set. But two factors were in opposition. It is not usual for a court decision readily to change long-established and passionately believed practices. Prayer and religious observances in Oregon schools occur today. Also, the Dickman court was a temporary majority, and, as personnel on the Court change, so does the interpretation of its laws. During the 1960s, the Court again approved Oregon's released-time law. The Attorney General advised that distribution of Gideon Bibles to schoolchildren was a violation of law, but approved of prayer at commencements and non-compulsory baccalaureate services. The State Board of Education, assisted by the ACLU, drafted a Model Policy of a strictly separationist nature for Oregon Schools, but that policy had no legal force and was largely unobserved.

From 1969 to 1977, Oregon's most interesting and strange case on religion worked its way through the state and federal courts. The Eugene Cross Case, Lowe $v$ City of Eugene, was an attempt to force the removal of a large cross from the top of Skinner's Butte in Eugene. In the early 1920s, the Butte had been one of the favorite places in the state for the burning of 
crosses by the Klan.77 A cross had dominated the Butte, in one form or another, since at least the 1930 s, on city-owned property. It is still there today, visible all over the City.

A trial court found in 1969 that the cross violated principles of separation of church and state, and ordered it removed. The Oregon Supreme Court first held that the cross could stay (on a 4-3 vote). After change of personnel, the Court reheard the case, and now said the cross was not permissable and ordered it removed. The U.S. Supreme Court refused to get involved. Although the Oregon Supreme Court had ordered the cross removed, it was still there eight years later when the case again came before the Court, now again with changed personnel. This third time, the Court declared the cross could stay as a secular monument.

This time, the Court did look at history. It found that Americans regularly used religious symbols as part of their secular life, and that this was permissable. In passing, it mentioned Christmas trees, stars, and cemetery crosses. To the public, what mostly became clear was that it mattered who the judges were that heard a case. The 1977 Court displayed a respect for the experiences of the people, the till-now "silent history".

...many crosses and other religious symbols traditionally have been used as monuments and memorials upon public property throughout Oregon and the United States, without appellate court challenge...This, in itself, is indicative of a feeling among a people who strongly support a constitutional government, that there is no constitutional question involyed in such a case, or it is so minimal as not to merit notice. 78

After the 1977 Cross Case decision, a crescendo of cases were brought. The Cross Case was frequently ignored (with its holding that the Oregon and federal Constitutions should be interpreted in like manner) and the more narrow Dickman case followed, which held that Oregon's Constitution imposed more restrictions. In 1972 , supporters of aid to religious schools had sought a 
constitutional amendment of their own. They wanted the State Constitution to read like the federal First Amendment, which was then held to allow some aid to religion. This initiative, which sought to overturn Dickman, did not pass, but the final Cross Case decision which re-aligned the two Constitutions, achieved its goals. 79

In 1973 separationists again attacked both shared-time and releasedtime school arrangements in Clackamas County. The Fisher case prohibited the first, and allowed the latter. In 1975, the Attorney General approved religious displays in schools, so long as there was equal access for nonreligious displays.

The pace of litigation and lawmaking continued into the 1980s. Incidents of racial and religious bigotry occurred: defacement of synagogues, paintings of swaztikas, plantings of crosses and Klan symbols. The legislature made racial and religious intimidation crimes amid concerns that this might limit free speech.

The 1971 legislature, in a manner suggested by ACLU, passed a law which provided funds to all Oregon colleges based on their number of Oregon students. This included denominational colleges. Nonetheless, ACLU filed suit against the program in 1981 in Cogan $v$ Atiyeh. The religious colleges, fearing that the entire program might be destroyed and faced with forced recoupment of ten years of funds if they lost, voluntarily withdrew from the program, thus losing millions of dollars. 80 The legal issue was not decided.

The "Cults" -- especially Scientology and Rajneeshism -- dominated the headlines in the late 1970s and early 1980s, and found themselves in court with depressing frequency. In a major damage case against the Church of Scientology, Kristofferson, where a jury first awarded significant damages, the Oregon Appeals Court reversed, saying there could be no inquiry into the 
sincerity of religious belief. The arrival of the Bhagwan Shree Rajneesh and his followers has led to over one hundred lawsuits and hearings, on many issues but with religion aiways a factor. The Bhagwan asked the courts to protect his vow of silence. They provided some accommodation, but were unwilling absolutely to do so. The Attorney General, after first declaring the City of Rajneespuram unconstitutional because it was religiously run, filed suit in state court to disincorporate it. That suit, still pending, has bounced back and forth from state to federal court. Surveys have shown tremendous religious bias against this group in Oregon.

Four other major areas of cases have occured in the 1980s. The Oregon Supreme Court has told Salem Academy that churches must pay unemployment taxes for their employees, in spite of a federal exemption. Judge Linde, with a new majority, reversed the holding of the 1944 Thorton case and of the Eugene Cross Case, and held that Oregon's religion clauses were now to be interpreted more narrowly than the federal. He also reminded readers that tax exemptions were a gift of the state. Students of Oregon tax decisions have noticed that, as on the federal level, there have been increasing litigation and unfavorable tax decisions towards churches in the last two decades. Separate Multnomah County courts have prohibited prayer at a high school graduation exercise, Kay $v$ David Douglas High School, and prohibited a prayer day service in Portland city council chambers, Wells v Ivancie, while allowing it in the adjacent city park. Finally, the Garb Bill of the 1922-Klan Era was attacked, when a teacher was dismissed because she wore a Sikh headgear in school. That suit was compromised in 1985, just as the legislature was prepared to eliminate the law 81 . It remains in the books. After 105 years of constitutional silence, religion has now become a matter of daily headlines, as the legislature, executive and courts pronounce 
upon it and intervene in it. There are now over one hundred reported Oregon cases on religion. Why now...after 105 years of State Constitutional silence ... after 160 years of federal silence? Why now?

There are many answers. In most states and as with the United States, the courts have always been slow to take on powers of judicial review. In a state's first years, as Friedman points out in his History of American Law, 82 as with the federal government, the legislature is first dominant. It includes those who framed the Constitution, and who know well what it meant. Constitutional history is their own history, and their own beliefs and practices form its application. Over time, the executive acquires more power. Only much later, as memories fade and as courts learn to mediate between legislature and executive, do they acquire confidence and assert powers of substantial judicial review. The states were also emboldened after 1947 by the innovating example of the U.S. Supreme Court. The Dickman and second Eugene Cross Case majorities were capable and sincere judges who believed that judges should make law and mould living and evolving constitutions to their view of the good society. Unfortunately, that approach left the meaning of the Oregon Constitution dependent upon who was on the bench on any given day.

The tremendous increases in federal programs under Roosevelt in the 1930 s and again under Johnson in the 1960s made the federal First Amendment and other constitutional provisions apply much more broadly than before. Entire new areas were opened to federal regulation.

Another answer can be found in the a-historical nature of Americans. Although in some ways we are obsessed with history, at our roots we, of all the people of the world, concur with Henry Ford that "history is bunk" and we ignore it. We have been a predominatly Protestant nation, whose people 
have always gone directly to the Book, whether Bible or Constitution, and counted for little the years of interpretation or experience that came between. One man, we feel, can read the Bible, or the Constitution, as well as any other man. What care Oregonians in the 1980 s how an American or Oregonian of the 1880 s may have understood Constitutional meanings. Most of us implicitly approve a new understanding fit for a new age. But we also hold our judges to a standard. They must interpret our Tables of Laws, and they are caught in the conflict of our demands.

As Tocqueville realized in the 1830 s, our democracy is especially prey to innovation and easily detached from the past. Our courts make history, but alas, too seldom respect it.

Now that the U.S. Supreme Court appears to many to be abandoning the strict separationism of the post-1947 period, separationists are turning with renewed vigor to state courts and state constitutions to mold their visions of our society. As they do so, Oregonians should require that "a decent respect for the opinions of mankind" demand that this revolution also state its reasons and give the history underlying its efforts.

With a sense of history informing courts, decisions could have been, and might be, different. Mark deWolf Howe, in The Garden and the Wilderness, shows how it matters if one derives the metaphor of the wall of separation of church and state from Roger Williams instead of from Thomas Jefferson, the first friendly, the second unfriendly to religion. In Oregon legal and general history, respect for the origins of and precise language of the religion clauses, respect for the expressions through their history of what Oregon's people believed their constitution to mean, might have produced different rulings. How, for example, can a decision forbidding aid to denominational schools be reconciled with Matthew Deady's remarks at the 
Constitutional Convention suggesting that all schools could draw from the common fund? How can a decision prohibiting a day of prayer in Portland City Council be reconciled with the debate at the Constitutional Convention which expressly approved chaplains appearing before the legislature?

With a sense of history behind him, the Mayor of Portland in 1982 might well have intoned to the Court, in Websterian manner:

I take my stand with Matthew Deady and the Founders of Oregon in Constitutional Convention in 1857. With them I vote to invite prayer to be said before the Council. They wrote that right forever into the Constitution of Oregon. Let any judge who would take it away show by what authority the people of Oregon allow him.

A better sense of the history of religion in Oregon, and of how Oregonians have themselves acted out their beliefs since 1857, should be an essential part of every collision of law and religion in Oregon. The people of Oregon are and remain the first and original branch of government, to whom the judicial, legislative, and executive branches should ever turn attentive ear. The people express themselves through their history. It is to that history, "indicative of a feeling among a people who strongly support a constitutional government," that all should turn when seeking to apply law to religion in Oregon. 


\section{PRIVATE PARTIES, CHURCHES, AND THE STATE}

\section{(A) Charitable Immunity:}

Until well past the halfway point of the 20th Century, churches and other charitable institutions in the United States were generally immune from liability for torts (negligence, defamation, etc.). They could not be sued. Society and courts justified this immunity on several bases: that to allow suits would discourage or destroy charity; that a charity's assets were held in trust and could not be allowed to be diverted; that in any case it made no difference because most charities had no assets to satisfy a judgement.

During this century, academics, writers and reformers had begun to advocate removal of this immunity. In 1936, two articles appeared in the Oregon Law Review, one arguing for and one against charitable immunity. In 1951, another article appeared opposing such immunity. In 1953, a review of a book opposing immunity appeared, followed in 1958 by a review of a 1955 Oregon Supreme Court decision which had said that it was the place of the Oregon legislature, not the Court, to change the immunity rule.

In the 1960 s, as part of a growing nationwide trend, the legislature did end charitable immunity. This removal was a traumatic shock to hospitals, and doctors, who were forced down from their "Magic Mountain" 83 into the real world of total liability. For churches, the effects have been more gradual, but no less profound. Subjection to total liability has increasingly led to professionalization of charity. The removal of immunity coincided with the rise of insurance which enabled churches and other charities to bear losses and still continue to operate. Insurance had undermined the rationale for total immunity. However, even churches which failed to obtain insurance mostly remained protected by their lack of money against which a judgement could be taken. 
There are therefore few reported cases against churches. In 1937, a visitor to the Pirst Congregational Church of Portland, who went into the church to interview the minister, fell down the stairs while looking for the lavatory. He sued both the church and the church trustees individually under tort theories of negligence and nuisance. Recognizing the fact of charitable immunity, the plaintiff himself voluntarily dismissed the church as defendant. The court ruled he had no claim against the trustees either, ruling that as a mere licensee he took the premises as he found them.

In 1963,1966 , and 1975, after passage of the law ending immunity, three cases reached the appeals courts. Most cases are not appealled because they depend upon questions of fact, not of law. In the Benedictine Sisters case, the Supreme Court said that it was a question for the jury whether the quality of glass in a door window, which had broken and injured a child who pushed against it, was below community standards to such an extent as to render the Sisters liable. In 1963 the Court ruled for the Grant Park Baptist Church that a railed light-well was not a dangerous condition so as to make the church liable for negligence when a five year old child fell into it. In 1975, the Cornelius Christian Church was found liable for negligence after a softball player was injured when he fell into a hidden hole under the grass of a playing field which had been recently farmland. A statute exempted "agricultural land" from liability for negligence, but the Church was not allowed to hide behind this law.

The importance of examination of this area of law is that it leads one fully to recognize that law books, especially appellate reports (which are normally the only cases reported), may not contain any record of cases for many reasons. The dog that did not bark in the night, as Holmes (Sherlock, not Oliver Wendell) said, is important. 
In the tort area, until the 1960 s, churches along with other charities, doctors, hospitals and the like were shielded from lawsuits. The state had determined that although wrongs might occur, it would not recognize them. When the dam broke, it broke with a vengeance. Claims have increased exponentially, and fundamentally altered the world of charitable endeavor. Questions of liability, as much as needs, now predominate in the helping professions.

But reported court cases remain few. Many claims are handled by insurance. When there is no insurance, injured parties very of ten do not sue. Some are still reluctant to sue a charity or church. Others cannot afford to sue. Others, because the particular charity may have no resources, decline to sue because it would be a waste of time and money. Finally, for those who sue and even prevail, questions of liability in tort cases are usually questions of discretionary judgement by judge or jury about what actually occurred, what the facts were. Such decisions are seldom appealable to the higher courts. Although the legal landscape has changed radically, this is not yet reflected in the number of reported cases.

Analyses like these are important because they make clear the role of the state in making itself available or declining to make itself available as a forum or agent for private citizens to resolve their disputes. When the state will not recognize disputes by blacks alleging racial discrimination, those acts do not cease to exist, but the court records will not show them. For years, the state said it would not recognize any complaint in tort against a charity. The state was therefore an omnipresent but silent actor.

(B) Intra-Church Litigation:

In a similar way, the courts in the United States, and Oregon, decided very early that, though churches sought to use them to resolve 
internal disputes over fine points of doctrine, it was not the place of government to be so involved.

In Oregon, the 1893 case of Philomath College $v$ Wyat announced Oregon's adherence to the American Rule that courts would not interfere in ecclesiastical disputes. Or rather, it appeared to do so.84 Actually the Philomath case ranks with the Eugene Cross Cases in the confusion of its procedural history and its illustration of the importance of who judges are, rather than what the law is. The decision, which had the effect of affirming a lower court decision which announced that Courts should not intervene in church disputes, engaged in nearly one hundred pages of very close examination of church doctrine and history.

The Philomath College case involved a dispute over ownership of the property and church revenues of the church of the United Brethren In Christ, which had split into two factions, the Liberals and the Radicals.85 In adopting a new constitution at the national conference in 1889 by somewhat irregular procedures, the conference led to a walk-out, each group maintaining it was the true church, and going to courts around the country to assert their claims. Similar cases were decided in Pennsylvania, Indiana, Michigan, Illinois, Ohio, and Missouri. Similar questions had been raised in other churches, especially in the major divisions which occurred as a direct or indirect result of the Civil War, which affected nearly all of the major Protestant churches.86

The Brethren's 1831 Constitution required, before it could be changed, that two-thirds of the membership must request the change. The 1889 Convention was called by substantially fewer than two-thirds. The Convention adopted changes which led the Radicals to walk-out and reassemble nearby. They claimed that the group they left behind had left the true church by departure from constitutional procedure. 87 The Liberals left behind claimed 
that those who walked out voluntarily resigned. Each asked the courts to determine who was the true church.

In Oregon, there were then three judges on the Supreme Court. Judge Robert Bean, however, also served as Circuit Court Judge, and heard the case at the trial level. He ruled that the Church itself had determined that the new Constitution was valid, that although the changes were irregularly made, they were not substantial but essentially amounted to a codification of previously existing doctrines, and that the Church could deviate from correct procedures in non-essential respects and ratify the result. Although he announced adherence to the American Rule, his examination necessarily involved his determining what change was substantial and what was not. His language however stated that he was not enquiring into doctrine, but merely applying the church law as he found it, just as he would that of any other corporation.

When the case was appealed to the Supreme Court, Judge Bean could not participate, because he was the judge whose ruling was being appealed. Judges Frank Moore and William Lord heard argument in the case, and reversed Judge Bean, deciding that the irregularity of procedure invalidated the 1889 Constitution. On rehearing, the case was argued again, but before a decision could be made, Judge Charles Wolverton replaced Judge Lord. The case was argued once more, and this time Wolverton and Moore came down on different sides, one for the Radicals, one for the Liberals. This split had the effect of affirming the decision of Judge Bean on the trial level. The record of the case contains therefore a lengthy statement of facts, and then two opinions, each of which announce the American Rule, but each of which applied it diffently.

Judge Moore stated that when questions of faith or ecclesiastical law 
have been decided by the highest judicial tribunal provided for in a church organization, the civil courts will follow such decisions, but that the regularity and legality of legislative acts of churches were always open to investigation. He noted that "the respect which coordinate branches of a government owe one another ought also to exist between civil and religious bodies." 88

Judge Wolverton, on the contrary, analysed both church doctrine and the facts of the dispute and decided that the changes were not substantial and were ratified by the Convention and Church. He decided that "those who adhere to the new and reject the old are the meek and lowly followers of the real church, and, incidentally, are entitled to the occupation and enjoyment of the ecclesiastical revenues. ${ }^{189}$

Although the application cannot have been satisfactory in theory, the effect was that the majority could retain the church 90 and that a court of equity could announce a clear rule, but still find its way to an effectively "just" result. 91

That message surely contributed to the very few subsequent cases which followed on division of church property. These latter cases, involving small numbers of members and negligible amounts of property, were decided with more decorum and precision, and are not particularly worthy of remark save to make that point. Application of the American Rule effectively removed such disputes from the courts, and kept the Oregon courts uninvolved in disputes over doctrine.

Thereafter, intra-church legal disputes were handled much as internal disputes of any corporation. In 1882, e.g., a legal battle arose in the Oregon Lutheran churches over the will of Pastor A.E. Fridrichson, who left his church to the Missouri Synod with Pastor Edward Doering (the Lutheran "pioneer priest") as trustee. Scandanavian parishioners, who did not want the 
property in the hands of the German Lutherans, sued. The court ignored their wishes, even though they were the parishioners, and routinely upheld the will. 92

In the 1946 Banks case, a property deed was held invalid when the court found that there had not been notice to all of the church members in accordance with the usages of the church which the court held to have the effect of bylaws. The enquiry of the Court was entirely into questions of fact as to which persons were actually members and at what times, as it might have inquired of any corporation concerning its bylaws. In the 1981 Berean Baptist Church case, the court firmly stated that civil courts may not enquire into church doctrine to resolve church disputes. In the Berean case, the only allegation was that doctrinal differences caused the plaintiffs to leave the church, which had been converted from a member of the Conservative Baptist Association to an Independent Baptist Church. The Court found that this did not state a cause of action it could recognize. Actually, the facts before the trial court showed that the proper procedures had not been followed, but the court concluded that acting as a court of equity this did not matter. The church, it determined, would have died if the new people had not taken charge, and there was no real remedy for the disaffected.

The examples in this section illustrate that in analysing church-state relations, one must look not only to existing cases, but to underlying principles which prevent cases from being given legal recognition and remedies. The State may have an effective policy of non-recognition. It may, in other cases, have a firm policy, but not enforce that policy, so that the law will appear to be one thing, while practice may be the contrary (as in the case of school prayers and Bible readings). In any case, it must solve in some way the dilemma of finding an orderly process for the management of ecclesiastical 
affairs. That a choice has been made may not be at all apparent unless one studies the history, the choices of other times and places, and the roads not taken. Other American jurisdictions had given preference to democratic majorities. This had the effect in New England of disestablishing the Episcopal churches and preferring congregational churches. Other states by law required congregational forms, effectively outlawing or severely disadvantaging hierarchical churches such as the Roman Catholic. Again, some states refused to recognize the corporation sole (a corporation of one individual), but--as in Nebraska--forced the Roman Catholic Church to vest ownership of its properties in lay trustees. This procedure, which forced the church to act contrary to its long-established policies, created several notorious controversies where congregations sought to take or retain control of church property or appointment of the priest and suffered hierarchical sanction. The American Rule, adopted by Oregon at first in name and later in practice, was a choice among many alternatives, made after review of other states' development and practice. It allowed the state to remain on the face of it neutral and uninvolved in theological disputes. 


\section{TAXATION 93}

"The power to tax involves the power to destroy." 94 In English and continental history, churches were not only free of tax, but had their own court and tax systems. Indeed, at times they were able to use the state as their arm of enforcement and collection. Established churches in the New World imposed taxes before and after the Revolution, with the State as their agent. After the Revolution there were still nine established churches, ${ }^{95_{a}}$ majority of the thirteen states.

In colonial times, churches were not taxed because they were a part of the state. When legal separation of church and state later occurred, the customary exemption was continued and still later was extended to dissenting churches.

By the time Oregon was settled and its government formed in the 1840s, established churches in the United States were largely history. In principle, the founding fathers of the state determined that no individual would be forced to pay taxes to support state establishment of a particular religion.

This was, however, not done clearly. The Indiana Constitution, Article I, Section 4, from which the Oregon Constitution was drawn, had a provision barring establishments of religion. This was not carried forward into the Oregon Constitution (although this failure has not been accorded significance to date). 96

Methods of exemption vary state by state. Some constitutions require and some merely permit exemption. Others are silent and leave exemption up to the legislature. Most states limit the amount of property which may be exempt. Some use the test of ownership, some of area or value, some of actual use, and some use a mix of methods, but all use some technique to keep the 
extent of exemption under control.

Before 1917, Art IX, Sec I excused churches from taxation as the legislature deemed fit.97 The Oregon Constitution after 1917 neither imposed taxation upon churches nor excused them from taxation. It was therefore left to the legislature to set policy. The legislature, strongly supportive of educational, religious and charitable work, chose to exempt from taxation property belonging to such organizations, incorporated or not, which was actually being used for such purposes. Because the existence and extent of such taxation was a legislative matter, questions would therefore revolve around construction of the precise words in the statutes. An attempt was made in the 1923 House of Representatives to tax churches, in a bill favored by the anti-Catholic federation of Patriotic Societies, but it failed by a 24-35 vote. 98

The Oregon position, as it came to be interpreted, was a strict and rigorous one. It was assumed that taxation was the rule, and that any claim of exemption would be rigorously scrutinized.

There are few tax cases from the early days, reflecting in part the small role the state then played. Early cases involved inheritance taxes and ad valorem taxes on property. An Oregon income tax was not passed until 1923, and then promptly repealed.

The key early case was that of Benevolent Hibernian Association v Kelly, in 1895. That case involved the question of to what extent ad valorem taxes were assessable against the land and building of a Hibernian group providing membership and charitable services to some Irish. It was determined that an organization could be charitable even if its membership and services were not available to all. A rule of reasonable apportionment was also adopted. To the extent that the premises of the Society were actually used 
for charitable purposes, it would be exempt. This decision, though strict, was clearly accommodating. Other early cases were similarly favorable. In 1870, the Oregon Supreme Court, in a case involving the Methodist Episcopal Protestant Church, ruled that a religious corporation could receive a bequest. In 1888 it ruled, again in favor of the Methodists, that the property of an unincorporated religious association, conveyed to a literary association-Oregon State College--which was required to hold the property for the church's benefit, was valid. ${ }^{99}$

Again in 1890 it held that a devise was for a public charity where it was for the advancement of religion by the construction of a (Presbyterian) church.

In the early twentieth century, this accommodationist trend continued. In 1917, in Scott $v$ Roman Catholic Archbishop, the Supreme Court interpreted a deed, which contained explicit restrictive covenants for residential purposes, to allow the grantor broad powers of waiver. A Catholic Church, convent and school were allowed in spite of the objections of one of the other landowners. Similarly, the court enthusiastically found a Catholic Sisters of Mercy Hospital in Eugene to be a charitable and laudable exempt enterprise, even though it charged some patients and made money. This same pattern of broad exemption was continued when in 1933 a gift by will to the First Church of Christ Scientist for the Christian Science Monitor was held to be for religious purposes and exempt.

A different tide came increasingly to flow in the late 1940s, coincidentally with an increased federal role in both religious and state affairs. The Tax Commission began to assume a more active role in taxation. The 1949 case of Tax Commission $v$ Methodist Book Concern emphasized that Oregon was a State of strict construction as it disallowed exemption. In 
1954, the Court approved a will which made inheritance contingent upon a daughter not becoming or marrying a Catholic. Even though Oregon had passed a law determining that discrimination based on religion was contrary to state policy, and had expressly forbade such discrimination in employment and public accommodations, the court said that private parties retained the right to discriminate, however unreasonably. 100 In 1959, in a case involving Multnomah School of the Bible, the rule was relaxed to one of "strict but reasonable" construction. But 1961 saw a Methodist Home held not exempt, and 1963 saw the operations of the Methodist Board of Publication held not exempt. The court noted that federal law used the "destination of benefits" test, granting exemption where the income of a business went to charitable purposes, but that Oregon employed a test of strict construction, which focused upon and required actual use. Thus, although all the profit and benefits of the Church publishing business went to church exempt purposes, it was itself found not exempt.

Another 1963 decision, contrary to the spirit of the 1888 decision on the Methodists, held that property of a church was not exempt where the legal title was held by trustees. The Court announced that Oregon was concerned only with legal title.101 Thus, property of the First Evangelical United Brethren Church, although clearly used for religious purposes and otherwise exempt, was held not exempt.

This case also showed a further intensified presence of the state through the State Department of Revenue, 102 which henceforth became $a$ persistent litigator. In 1964, the Court again held against the Methodist Board of Publication. In 1967, it held that the Sisters of Charity, otherwise clearly exempt, waived that exemption by failing to claim it on time, and that the State Tax Commission was the place to seek relief, not the local courts or 
commissioners. In 1977 this principle was reaffirmed when the Pacific Conference of Bvangelical Churches was told that even though its failure to file timely was based upon the advice of a government official, its otherwise exempt conference center at Jennings Lodge could not be found exempt.

Again in 1971, when the Evangelical Lutheran Charity Board had acquired land for church and charitable purposes, the Court held that the property did not become exempt until actually used for such purposes. Land held for future use was held not exempt.

Somewhat less restrictively, in two companion cases, the Court found that the administrative center of the Protestant Episcopal Bishop and the chancery and newspaper (Sentinel) offices of the Catholic Archdiocese were exempt, because advancement of religion was held to be charitable. The cases followed in the line of Oregon Attorney General opinions which had long held that parsonages were not exempt, though churches and church-related activities were.

A 1972 ruling, though favorable, showed the increasingly unrelenting pressure of the Department of Revenue. In the case of the Evangelical Lutheran Good Samaritan Society, receipt of net income was held not to render a charitable/religious group non-exempt. Since the principle had long since been established in the 1923 Sisters of Mercy case, there was evident an attempt to change the law.

From 1972 on the cases flowed faster and faster, more and more restrictively. The fact of litigative pressure is obvious, even though some of the decisions were not initially unfavorable. A Christian Pre-school was found to be exempt but only after intensive scrutiny and under an analysis which had the result that much church-related child care would not be exempt. The 1974 Kelly case held that all income earned in an individual capacity was 
taxable. Land held by the St. Vincent dePaul Society was held not exempt when "merely held with intent to use for charitable purposes".

In 1976, the Church of Latter Day Saints (Mormons), was told by both Tax Court and Supreme Court that its farm, whose income all went to charity, could not be tax exempt. Again, it was emphasized that Oregon focused upon actual use, and was not a "destination of benefits" state. Another 1976 case, involving the German Apostolic Church, held that a statutory change had widened the concept of use, although the result seemed to be no more than an application of the Kelly principle of apportionment applied to exempt portions used for church activities, but not apartments. Analytically, it is a sign of the narrowing that a legislative change which restored the status quo ante was seen as a "widening". In a second LDS case, proper "use" was found and exemption granted where the delay in charitable use occurred only because of the government itself, whose permit requirements took time to obtain.

The 1970s and 1980s saw an assault upon churches by the State Employment Division, which failed several times before at last achieving success. In 1977, the recently established Court of Appeals held that church schools were not covered under the Federal Unemployment Tax Act (FUTA). In 1979, the Archdiocese of Portland was similarly held not covered. These cases corresponded with similar attacks upon churches nationwide, as the IRS and unfriendly private parties and labor unions sought to bring churches under federal labor and tax laws.

In 1980, the Appeals Court--with changed personnel--found that the Shiloh Youth Revival Center was covered "when its activities were of a type normally for profit and not integral to religious purposes". In 1981, the Supreme Court, in the Miller case, involving the Union Gospel Mission, held otherwise. 
The federal and state constitutions, previously not thought relevant, now came to be used to attack church exemptions.

The Supreme Court, with changed personnel, found its position shifting. In 1984, it ruled that a requirement, that Workers Compensation claimants could refuse treatment only when relying upon an accredited practitioner of a well-established church, would violate both the Oregon and Federal Constitutions. This court, like the federal courts, was beginning to extend the concept of religion so broadly that it would not for long be able to sustain church-related exemptions. 103

Indeed in 1985, in Salem Academy, a new landmark case, the Court held that even though the federal law "appeared" to require that churches be exempt from FUTA, it would separately interpret the Oregon Constitution to require that they be covered. The Court of Appeals had said that the distinction between recognized and unrecognized churches made the exemption law invalid. The Supreme Court held that the law was constitutional, but reached the same result by finding exemption could not be extended only to church-directed schools but not church-related schools.

Indeed, in several footnotes, Justice Linde, 104 the moving force on the Court in constitutional revision and strict separationalism, invited the legislature to consider disapproving all tax exemptions for churches. Speaker of the House Vera Katz had long held such a desire, and the footnotes have been interpreted by Charles Hinkle as an invitation to her to advance such proposals. 105

There are other Oregon tax cases which fit into the above patterns. As the state is seen by many to have the first obligation of charity and to be the institution of society which should have all or most responsibility for charity (now as a matter of right), 106 so its presence and financial needs 
seem to place it in competition with private charity. As in the field of education, that competition is not always expressed in direct form but in increasing financial pressures which lessen private parties' capacities to compete.

The state, so able to make fine distinctions in some areas, in others finds itself unable or unwilling to do so. It allows itself to lessen the protections and exemptions accorded churches, rarely by direct attack, but more often by requiring such an expansive definition of religion or church that protection appears to become a reductio.

In the 1980s, the state - acting through the Department of Education, the Attorney General and others - has been aggressively seeking ways to deny tax dollars to Rajneesh enterprises. This has led to ex parte accusations, unilateral suspension of payments, lawsuits and legislation.

When Oregon tax law and policy are seen in conjunction with other state policies and practices towards religious groups, the era of generous preferment is clearly past. Churches are now at best like other private charities. All are under increasing restriction. At worst, they are not allowed even the exemption granted other charities because they are religious. The state has become neither friendly nor neutral, but antagonistic. 


\section{THE OREGON SCHOOL BILL OF 1922}

In 1922, the Ku Klux Klan, appearing out of nowhere, took over the State of Oregon. In a very few months, operating behind a veil of secrecy, it defeated one governor foolhardy enough to oppose it, and elected another who eagerly embraced it. It controlled local of ficials across the State, dominated the legislature (whose Speaker was named K.K. Kubli), and passed laws banning religious garb in public schools and outlawing all private and parochial schools.

So goes the legend of Oregon history. It is true that the Klan briefly appeared in Oregon from 1921-1925. A Compulsory School Bill was passed which sought to require that all students attend public schools. But for that bill, the Klan was not primarily responsible ${ }^{107}$ and Oregon's Klan of the 1920s was very different from the Klan of today. Those differences, and the history of that Klan, require separate examination. Historians of the period have been too ready with epithet and mere charge, rather than evidence. Rather than the Klan, it was the "good people" of Oregon who conceived and passed the School Bill.108

There are at least two stories: what actually happened; and how it came to be told otherwise. The one is a story of history, the other of mythmaking. It is important to understand both of these stories because, although the Klan is gone, the forces that made for the School Bill have been in Oregon long before and long since.

The general public still scarcely knows the story of the School Bill, and it may come with ill grace to suggest it has the story wrong. But the 1984 publication of Father Lawrence Saalfeld's Forces Of Prejudice In Oregon, 1920-1925, done as a thesis in 1949, again draws attention to a moment when 
Oregon trod the national stage to its discredit. Articles and theses on the School Bill and the Klan, and general histories of the period which tend to rely upon them and reproduce their themes, stand substantially uncorrected. Both the event and the accounts need more exposure.

Readers of the history of the 1920s, nationally or in Oregon, will find those years facilely portrayed as a time of reaction, when the forces of fundamentalism and prejudice swept the country. Images of the decade have been crystallized by events such as the Scopes "Monkey Trial", the executions of Sacco and Vanzetti, the raillery of $H$. L. Mencken, the satire of Sinclair Lewis, and the anti-Republican writings of Arthur Schlesinger. Frederick Allen Lewis' Only Yesterday sets the tone. The Great War and the Great Depression limned the shores of memory, and all was seen as aftermath of the War or prelude to the Crash. The detail of events, as seen by the men who lived them, was too easily lost in such prepossessions. The times needed to heed the rebuke of an Edmund Burke or Samuel Johnson and be recalled to human and historical fidelity. Burke had said: "I do not know the method of drawing up an indictment against a whole people." 109

Fresh examination of "what actually happened" in the decade has begun to yield correction and more balanced explanation. Let us therefore examine the period of the School Bill with respect for the facts, for the individuals and their biographies, and for broader historical and political trends. Using our Occam's razor of historical technique, let us, before we must have recourse to concepts of group prejudice and disease concepts of moral history, review the plain facts.

In the general elections of 1922, Oregon voters approved Initiative 69, known as the Compulsory School Bill. The law, which would have gone into effect in 1926, provided that all children between the ages of eight and 
sixteen were to attend public schools and be educated in the English language only.

The Initiative petition was conceived and circulated by the Masons of Oregon, at the instance of the national Masonic Order. The Masons were advocating compulsory school and language bills nationally, and chose Oregon as a test case. In a dramatic one-day campaign in June of 1922, enough signatures were obtained to place it on the November ballot. At first, it was claimed that 50,000 signatures were gathered in that one day. Actually only 29,000 had been obtained, of which 13,000 were found invalid. Still, this was more than enough, and the 50,000 figure left an impression of overwhelming support.

The Masons filed the arguments in the Voters Pamphlet for the Bill. They wrote to and placed advertisements in the newspapers. When the bill passed, claimed victory. When the law was attacked in Court, the Masons defended it, at the trial court and before the U.S. Supreme Court. Today, in 1985, they still defend its rightness. 110

Who are and were the Masons? Seen today by most as a charitable society which wears funny hats and helps sick children, the Masons are a society of humanists which exists world-wide. They claim origins in ancient times, but their present forms derive from the Europe of 1782, when they formed an intellectual and fraternal secret society to advance men's knowledge and oppose despotic rule. The French Encyclopeadists were Masons, as were such of our Founders as Washington, Hamilton, and Franklin. Masons have since been in the forefront of independence movements around the world, with such luminaries as Goethe, Lafayette, Kossuth, Bolivar, and San Martin. Intellectual and political opposition to Catholicism, perceived as an opponent of free intellect and democracy, has also been part of Masonry's heritage. 
Those who know Catholic Church history well have long regretted her too ready defense of reactionary governments in Europe and elsewhere. 20th Century readers of Thomas Mann's The Magic Mountain will recognize the passions for freedom and intellect, and the hatred of the Catholic Church, which informed the Masons. Arising out of the Enlightenment, the Masons were committed to complete separation of church and state. The condemnation in the late 19th and early 20 th Centuries by the Catholic Church of secret societies was a direct attack upon them. Simultaneous condemnations of Americanism, Modernism, and of public schools only proved their views of the Church.

In 1920, the second post-War national Masonic convention was held in Portland. This move, engineered by Mason Mayor George Baker, made the national leadership familiar with Oregon. In the same year, Oregon's Masons adopted verbatim the national resolution calling for free and compulsory schools for all "as the only sure foundation for the perpetuation and preservation of our free institutions."111 Over 20 other states passed laws to require education in English alone, but Oregon was chosen for this test "because she has no foreign element to contend with and is, more that any other state, purely and fundamentally American."112 This conclusion was based upon Oregon's homogeneous population, its solid Protestantism, its common origins in New England and the Middle West, and its demonstrated patriotism in the recent War. It was hoped that Oregon would prove an "example for the rest of the country".113 The Masons believed, with the experiences and the War years just behind them, that private schools were being used by the immigrant and church groups to continue to maintain divided loyalties, class differences, and opposition to American ideas of democratic practice. They believed, with educator John Dewey, that education was "the 
fundamental method of social progress and reform."114

The Oregonian, although it opposed the School Bill, properly gave credit in a 1922 editorial to both the aims and effect of the Masons:

It is not necessary to say that so patriotic, respectable and influential an organization as the Masons(Scottish Rite) would not sponsor any measure without a conscientious desire to promote the public welfare. 115

The Bill's opponents, especially the Catholics and Governor Olcott, scored a major victory in successfully ignoring the role of the Masons and of the common school movement, and in attributing it to the Klan. That characterization, belied upon close examination, mobilized national criticism of Oregon and aided in the law's eventual defeat.

Many accounts of the School Bill are actually accounts of the Klan in Oregon. By providing such emphasis on the Klan, they leave the intended impression that the Klan was the major, if not the only, real force behind its adoption. The success of the one is held to demonstrate the success of the other.

The Klan was formed in Portland in late 1921. The federation of Patriotic Societies (of which the Klan was not a member, and never could become one) caused the concept of compulsory school bill to become an issue in the 1922 Primary. Republican Candidate Charles Hall announced his support. When Republican Governor Ben Olcott, who in late 1921 had told a national paper that the Klan did not exist and could never take hold in Oregon, just five days before the Primary publicly attacked the Klan, it threw its support to Hall. Olcott, based upon incidents of violence in southern Oregon (never firmly tied to the Klan), issued a Proclamation accusing the Klan of violence and of religious intolerance. When Democratic Party Catholies and others crossed over to vote in the Republican Primary, Hall lost, 
but by a bare 500 votes. He at first sued for a recount (W.S. U'Ren, ACLU correspondent in Oregon and Father of the Progressive System, was his lawyer. His campaign manager was Jewish.), but when election day crossovers were held legal, the suit was abandoned. He considered running as an independent, but discovered that this was prohibited by Oregon law.

The Masons, persuaded of the support for the School Bill, introduced their Initiative in June. The Klan wavered. When it was clear that Hall could not run, Klan support was given to Democrat Walter Pierce. The Klan, enemies of Olcott, had no other place to go. Pierce indicated he supported the School Bill, and emphesized his descent from nine generations of Protestants, but also made clear that he would run, as he did, solely on the question of taxes.

Pierce, a former school teacher and school superintendent, was a long-time Mason, and an admirer of the agnostic and anti-Catholic Robert Ingersoll. Lifelong he believed that Catholicism was a political force opposed to democracy. He worked for absolute separation of Church and State so as to prevent religious intrusion into public life. There are allegations that Pierce was a member of the Klan, but Pierce denied them, and the evidence is not credible that he was ever a Klan member, though it appears he did not reject Klan support in the campaign. At the time, Pierce expected the School Bill to lose, and estimated it would cost him 10,000 votes.

During the Primary, Catholics, Lutherans, private school forces and others had organized to defeat Hall, symbol of the School Bill. Upon his defeat, they thought they had won. When the Masons dramatically announced the simultaneous filing and 50,000 signatures, they recognized their limited resources and sought national support. The Knights of Columbus and National Catholic Welfare Conference (the national conference of Catholic Bishops) 
aided with money, legal advice, and publicity. Within Oregon, the Catholic Truth Society, led by Father Edwin O'Hara and Father Smith, dogged each pro-Bill speaker and countered with the Catholic response. Father O'Hara, a nationally known figure for his work in labor and education, was the most eloquent opponent. O'Hara had been the key figure in passage of Oregon's protective labor laws for women and children, and placed his name on the successful defenses of those laws before the U.S. Supreme Court. As a result, he directly knew such figures as Supreme Court Justice Louis Brandeis (who, as lawyer, had argued the famous Muller case from Oregon), and could call upon national leaders. Even American Civil Liberties head Roger Baldwin helped O'Hara find a lawyer.

These impressive efforts failed to defeat the law, but did generate national attention for Oregon, most of it unfavorable. How, newspapers asked, could the progressive state of U'Ren, of Oswald West, of the Initiative and Referendum, now be under the thumb of the Klan? The law's opponents sought to portray it as the work of the Klan. Indeed, one editor, George Putnam, raged at the "conspiracy" on the part of the other Oregon press because they would not agree with his analysis that the Klan was behind it all. Putnam's analysis, given in such impartial languaage as: "Dangerous forces are insidiously gaining a foothold in Oregon",116 suffers from inaccuracy and passion. Major newspapers such as The Oregonian had very publicly opposed the Klan as early as 1921 , continued to speak against it, and attributed the Bill to the Masons, not to the Klan. Putnam's Salem paper, major papers from Portland and Medford, and of course, the Catholic Sentinel, vigorously identified the Bill with the Klan and attacked both. National media in Oregon also attacked both. The Letters columns of many Oregon papers, and widely distributed pamphlets, debated the Bill. One can do worse than 
take The Oregonian as a guide to these events. Putnam, the "crusading editor", had little respect for evidence and was such a partisan that he was arrested on Primary day for changing parties to vote against Hall (he was acquitted after a ruling that election day crossovers were legal).

The Klan in Oregon was led by Fredrick Gifford, indeed a Klansman to defy stereotypes. Educated in Lutheran schools, he married a practising Catholic and had his three children educated in Hill Military Academy and St. Mary's Academy of the Society of Sisters (the later Plaintiffs in the court case). He remained friendly to Catholics all his life, and there is evidence that he was threatened with expulsion from the Klan because he was too friendly to Catholies. Gifford's Klan will not match the ideas most people today have of the Klan. A prime example is the School Bill itself. In Oregon, the School Bill sought to join in one common public school all races, religions, and classes, to educate them together for citizenship in the American democracy. The Oregon Klan had auxiliaries for non-natives. The other respect in which it defies people's expectations of it is that it was largely ineffective. Its membership in Portland and Oregon never rose above 14,000 , and many of those were but paper members. It was unable to secure the memberships of such figures as Hall, Baker, and Pierce, and all were soon publicly to repudiate it. The Masons, nationally and in Oregon, announced that they would dismiss any Mason found also to be Klan member. The Oregon Klan was unable either to get accepted into, or take over, the Federation of Patriotic Societies. A close study of voting patterns in the State shows that where its slate differed from that of the Patriotic Societies, it was not successful. Two Portland politicians identified with the Klan were soon recalled. Governor Pierce refused the patronage which the Klan claimed that candidate Pierce had offered. Its leading publicist Lem Dever soon quit and 
published a bitter attack. The Patriotic Societies sued the Klan in court, the revelations of which, combined with financial scandal, caused members to melt away like the proverbial morning dew. By 1924, the Klan was not to be found. Its paper, The Western American, which in its day had eulogized Father O'Hara and his work for the laboring man, considered the Masons the true force and victors in passage of the School Bill, a claim a fortiori likely because it was made by the normally self-aggrandizing Klan. What the Klan did bring to Oregon was a dramatic brief presence. Like the American Protective Association, and the American or Know-Nothing Parties before it, however, the Klan had little actual membership or real power in Oregon. One writer once joked that in Atlanta, headquarters of the Klan, the B'nai B'rith had more members and influence. Certainly, in Oregon, there were more Catholics in Portland than there were Klansmen. The Klan played no role in the Initiative or defense of the case, and were dissolved before it was argued and lost in the U.S. Supreme Court.

Upon the passage of the School Bill, not scheduled to take effect until 1926, opponents had a problem. Under existing law, it did not appear they could sue to prevent a distant future harm; there was no precedent overturning such a law; and education was an area of law considered reserved to the states. Yet if they waited, their schools would be destroyed long before 1926. They studied, and waited, and waited...Finally, in 1923, the U.S. Supreme Court in the case of Meyer $\mathbf{v}$ Nebraska struck down a Nebraska law which required, on criminal penalty, that all schools be conducted in English. Another court provided a precedent for suing to prevent future injuries. Only then did the Plaintiffs sue in federal district court in Portland, first the Hill Academy and then the Catholic Society of Sisters. Due to a clerical accident, the Sisters' case was called first, and so gave its name to the consolidated 
case. The schools' lawyers included former legislator Dan Malarkey and future Oregon Supreme Court Justice Hall S. Lusk. Lawyers assisting Governor Pierce and the State were Wallace McCamant and, on appeal, former Governor and U.S. Senator George Chamberlain.

The Meyer case had shown that the Supreme Court would intervene in a state education case. In so doing, Justice McReynolds departed from current stereotypes of himself as arch-reactionary and automatic supporter of states' rights. The Pierce case was argued before the district court in early 1924. The schools' lawyers used analogies, derived from Father O'Hara's pamphlets, presenting the Bill somewhat confusedly as all at once a Platonic, Prussian, Spartan, and communistic attempt of the state to take over education. (Of course, the common school was precisely not like the schools of Sparta, the Republic, or Prussia, which admitted only the chosen few. The case shows once again the power of metaphor, especially misplaced metaphor, to shape legal decisions about religion). It also helps to remember that Oregon had a long tradition of unfriendliness to public, as opposed to private, education. The schools' attorneys quoted from Meyer verbatim and at length, anticipating later appeal to McReynolds and his Brethren. In April, the three-judge court found the new law was unconstitutional. It was held a violation of the private schools' contract rights, which the State might reasonably regulate but not destroy, and of the parents' (although they were not parties) rights to determine the education of their children.

On appeal to the U.S. Supreme Court, the Masons had no chance. Not only the Mejer precedent, but a headcount of the Justices must have discouraged them. There is evidence that Holmes, the "great liberal", who had dissented in Meyer did not attend the oral argument and may not have voted at all.117 He was the only uncertain vote, with his disposition to let 
the people regulate themselves, even to Hell, if they would. McReynolds was a passionate supporter of private schools. Two Justices, McKenna and Butler, were Catholic. Chief Justice Taft was a Unitarian, who, when President, had appointed the Catholic White as his predecessor, Sutherland was well known to be friendly to Catholics. Sutherland was Morman and a student of Judge Cooley: unlikely to support an anti-religious measure. Sanford had a degree in education and was educated in private schools. Van Devanter later joined the 1929 decision which, forcing the Klan to disclose its records, completed its destruction on the national level. Brandeis, a Jew, had been an ally of Father O'Hara who, through Felix Frankfurter, continued to have his ear. The Republican Court had little reason to oppose national opinion or to favor a Democratic Governor. The unanimous decision by Justice McReynolds was a landmark decision, and continues to be extensively relied upon today. McReynolds wrote that "The child is not the mere creature of the State", and that the American system "excludes any general power to standardize its children". An irony of the case is that McReynolds, today mostly seen as the arch-opponent of the New Deal, led this seminal intrusion into state affairs.

The Masons had chosen Oregon as a test case, and so it proved to be, to their chagrin. The Catholics, at first dismayed, came to see the case as a blessing in disguise. The right to private schools and to parental direction of education was now enshrined in the federal Constitution.

The role of the Progressives and of supporters of the common school should also not be lost sight of. In the 1800 s Horace Mann and his disciple Henry Barnard had sought to shape society through the common compulsory school. In the 20th Century, John Dewey also believed that private schools should disappear, not by compulsion, but because they would not and should not compete with the public schools. Dewey and Mann rejected private 
schools as inimical to American democracy, and Henry Barnard advocated their outright abolition. Their positions then compare to that of educational associations and liberals today, who continue to $f$ ind in the common school the panacea for society's problems. Then, as now, progressives generally revere the public school, and conservatives the private. Interestingly, it is today's liberal groups like the American Civil Liberties Union who support the garb bill and do much to weaken private schools to favor the public. These positions may or may not be prejudicial, but it is worth noting those who hold them. Are they prejudiced today because they assert what the Klan did in the 1920s? Historian David Tyack has written:

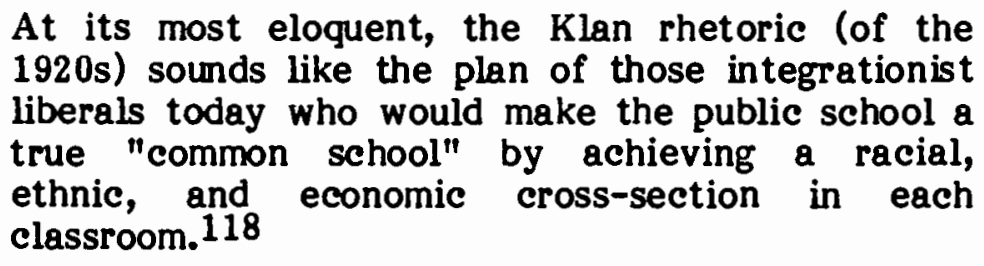

The Klan of the 1920s, contrary to the beliefs of many today about it, wished all children in the same classroom, whatever the race or religion. In these beliefs, and in their intent, they were heir to the progressive educator. Steven Recken, one of the most insightful analysts of those days, concludes that "Neither the Klan nor the Masons were as responsible for the Oregon School Bill as were Horace Mann and John Dewey." 119

Without discounting the existence of the Klan and of some prejudice, and fully allowing for the Masons and Progressive educational forces, one may disabuse preconceptions with the contrariness of facts. For example, is it likely that Hall would have been a Klan member and defended by U'Ren? or have a Jewish campaign manager? Do many analysts recall, have they learned, that Olcott was highly unpopular in his own party and was an appointed governor with little following? Do they know that Pierce--known even in 1918 as "Mr. Democrat"-- was widely popular and had been expected to win 
in 1918 until an inopportune remark by Woodrow Wilson and the flu epidemic ruined his chances. He had been expected to win against the popular Governor Withycombe, and benefited from substantial democratic voting in 1922. Pierce in 1922 did not need the Klan, and thought his support of the School bill would cost him votes. One can recite such anomalies at length, to show that the image of the State and election as Klan-determined, or even solely School Bill or Mason-determined was not only not the case, but would violate the normal rules of politics, and the complex political histories which brought each of the parties to those years. Historians' accounts of the Klan and School bill suffer from many defects. There are major factual errors, mere charges accepted as evidence, isolated incidents treated as though they revealed majority behavior, assertions that all must have been prejudiced because a few clearly were. Two major errors recur. A near-total focus on the Klan in telling the School Bill story gives the Klan the appearance of undue importance. Most writers are trying to explain the phenomenon of the Klan, rather than the events. Proper attention to the party politics and voting patterns of the period, as well as regional factors--what should be normal analysis--renders a very different picture, in which Pierce's victory can be explained without the School bill or the Klan. Similarly, a near-total focus on behavior alleged to be prejudicial gives it undue prominence, and fails to allow the normal and particular reasons of actual individuals proper respect. The reasoning of some historians is circular. 
The garb bill is said to be prejudiced because the Klan supported it, and the Klan to be prejudiced because it supported the garb bill. The Klan is said to have run the State because the garb bill was passed, and the garb bill to have been passed because the Klan ran the State. Oregon's general historians appear to have given little direct attention to this period, as is revealed by fundamental factual errors which could not have occurred had they given it independent thought.

The historians of the 1920 s and of the Oregon School Bill have suffered from partial and biased accounts with overemphasis on the role of the $\mathrm{Ku}$ Klux Klan and upon shadowy forces of prejudice and bigotry. These forces are all too inaccessible to research, and lead to poor use of evidence and logic. Histories based upon them fail for the most part to search for and present complex motivations or explanations. There is too much review of "forces" and too little of real individuals, and what they believed and did.

When the issues surrounding the School Bill are reduced to study of major actors in its passage and defeat, stereotypes and preconceptions prove of little value. The neglected initiator and defender of the Bill was the Masons. Even the Oregon Klan, though its role was less than has been supposed, was a very different Klan than most have imagined. Concentration on forces and statistics has allowed historians not to present the reality of these groups and individuals such as Olcott, Hall, Pierce, Gifford, Baker, O'Hara, or McReynolds. A review of the histories of the period shows this consistent neglect and an overemphasis on the imagined role of the Klan.

Consideration of the biographies and moving forces in the lives of Gifford, O'Hara, Pierce, McReynolds does much to remove preconceptions and restore the issues of that day to their proper complexity. 
Historians of the 1920s have for too long presented the period as one of backwardness and prejudice, and failed to search for its positive forces or the darker sides of forces viewed by the historians as progressive or enlightened (both small and capital). Out of the many studies which now exist of this period in Oregon, presenting a mosaic of increasing complexity, this essay develops a re-evaluation through the methods of presentation of the Masonic role, criticism of existing accounts, and review of major biographies.

Gifford emerges as a Mason and a Klansman, but a Klansman who rejected violence and was friendly to Catholics. Pierce, a noted Democrat, populist and later New Dealer, had a lifelong animus against aliens and Japanese, but through his admiration of Ingersoll, his Masonic leanings, and his role as teacher and school superintendent, developed a firm devotion to the common school and to absolute separation of church and state. Father O'Hara, the sophisticated Catholic priest and historian, companion to local and national social welfare and educational elites, is seen to have successfully led an opposition which recruited the ACLU and even, waveringly, John Dewey himself, and to have placed natural law ideas into the mouth of a Supreme Court Justice. Justice McReynolds, for too long characterized as racist and reactionary, emerges as a champion of private schools and individual liberty.

The Pierce case and the School Bill controversy well illustrate that appearances and labels can be deceptive, that easy and convenient attributions may prove wide of the mark. When alternative theories of the origin of the School bill, other than the Klan and prejudice, are presented, whether they show the Bill as the product of Progressive educational thought, as an expression of agrarian protest, or as the product of Masonic enlightenment theories and beliefs, both the characters and the facts more easily can be found to fit. The contradictions of accounts such as those of Kenneth 
Jackson ${ }^{120}$ or Father Saalfeld are then easily explained. Of course, no history can hope to capture the infinite complexities of men, but one must keep testing the evidence for a more coherent account, seeking in the best scientific and human spirit one which does not rely upon imagined and, in the end, unobservable forces.

No character or group emerges from this analysis with a pure or correct mix of beliefs. The Pierce case well illustrates that the divisions of that day were found not only among groups, but within them, not only among individuals, but within them. As Kenneth Jackson said of the Klan, so also it should be said of the School Bill (parentheses added):

\begin{abstract}
Because it is more important to understand than to condemn, the text does not ring with denunciations of intolerance. The task is to examine...In the final analysis, the Klan (School bill) was not alien to society or unAmerican. If it were, the Problem would have been much simpler. Rather the Klan (School Bill) was typically American. It prospered and grew to national power by capitalizing on forces already existent in American society: our readiness to ascribe all good or all evil to those religions, races, or economic philosophies with which we agree or disagree, and our tendencies to profess the highest ideals while actually exhibiting the basest of prejudices. To examine the Klan (School Bill) is to examine ourselves.121
\end{abstract}

With the caveat that historians, including Jackson, have too often behaved towards the School Bill and its supporters in the manner of easy condemnation they profess to disapprove in the Klan, it is proper to end with the statement that in searching for darker forces and motivations, which as children of Freud and Darwin our century destines us to do, we should not forget the open and obvious, and fail to credit what we can directly observe.

The Greeks have told us that not even God can change the past, but our age knows that historians can. History therefore becomes for us not merely a science or an art, but a moral task. To that task, we must bend all 
of our human faculties, but remember that it is humans like ourselves whom we are studying. Courtesy and evidence, respect for the best of men's motives and actions, must be as much a part of our search as properly considered charges and suspicions, weighed across the years and often without the subject able to explain himself. The period of the School Bill in Oregon can be a metaphor for prejudice, latent and revived. It can be a story of an excess, well-intentioned but best failed. It can be the story of a life, such as that of Pierce, which may never yield an answer as to his relation with the Klan, whether he merely used them, belonged, or allowed himself to appear to belong. In searching the period, we should be content with what it reveals, without the need to make it show us a false image of Oregonians as tragically tainted with prejudice which must needs recur on some Atropic schedule. The fault is not in the stars but in individuals. 


\section{VII - DISSIDENT AND MINORITY CHURCHES}

The history of religion often appears to be the history of the development of differences among churches and the recruitment of the state to support one side against the other. One may with confidence assume that new or minority religions will face not only general resistance but legal resistance as well. Indeed, revolutionary visions often invite supression by the vigor and violence of their condemnation of the existing order or orthodoxies. This has certainly been true for Oregon.

To understand the reception given new churches in Oregon, one must have some knowledge of that group's position in the country at the time. Oregon's reception, though it may have varied in intensity, was generally of a piece with that of other states. The reception of Jehovah's Witnesses and of the Russian Old Believers was demonstrably influenced by the U.S. Supreme Court decisions which accorded them protection and affirmative accommodation. The Old Believers came to public attention in Oregon after the Amish Yoder case had given license for their way of life. That they came as refugees from communist countries further worked in their favor and minimized local conflict.

Below, brief descriptions are given of major minority religions or "cults" and their legal reception within the state of Oregon.

\section{(1) The Catholic Church.122}

From the earliest days, the Catholic Church has faced real and threatened disfavor. The American-British dispute over the Oregon Territory took on religious overtones, accented by the shameful treatment of McLoughlin's Oregon City land claims. After the Whitman Massacre, and attempts to place the blame on Catholic priests for instigating it, a law was proposed which would have exiled all Catholic priests from the Territory. The 
very record of the 1857 Constitutional Convention, in the discussion of Article I, Section 5, on chaplains, contains the observation by member Waymire that "Suppose a Roman Catholic should be elected Chaplain; every other religious demonination in Oregon would be in open rebellion." Papal condemnation of Masonry and other secret societies, of Modernism and Americanism, and Rome's untimely endorsement of the principle of papal infallibility and of the Immaculate Conception, led Catholics and Protestants to pull apart from each other in distrust and distaste. Catholies saw nativist sentiments and movements successfully tighten immigration laws in order to prevent continued entry of their co-believers. The laws were also used to prevent entry and effect deportation of ethnic church members, including German nationality churches, many of which were Catholic.

The major legal attacks upon Catholicism began in the 1920s. The Oregon School Bill, passed by Initiative in 1922, would have required all students under 16 to attend only public schools, with all teaching in the English language. 123 The 1923 legislature also passed the Religious Garb Bill, designed to remove Catholic nuns from teaching in Oregon public schools and to impose criminal penalties for boards which refused to enforce the law. Prior to this time a number of Catholic rural communities had, persuaded by economics, consolidated parochial and public schools with the nuns teaching and being paid by the State. The legislature also considered making sacramental wine illegal, and cancelling Columbus Day as a holiday.

Mostly the agencies of government chose not to intervene when private parties and groups chose to discriminate on the basis of religion. Catholics as well as Jews were excluded from employment, clubs and associations well into the 1970s. Even the ecumenical movement did not accumulate enough force until 1979 to allow the Canby Ministers Association to admit a Catholic priest 
as member. 124 In the 1954 Snodgrass case, the Oregon Supreme Court, even after the State had passed laws forbidding discrimination based upon religion, firmly supported the rights of private parties to discriminate and to use State agencies and courts as vehicles to enforce their will.

Many laws, such as one proposed to prohibit any but American flags flying outside of public buildings, would not seem anti-religious unless one knew they were designed to prevent Irish Catholics from flying the Irish flag on St. Patrick's Day.

Although parochial schools were now protected by law, after 1925 they were not protected from economics. It cost money to run the schools, and Catholics were being taxed to operate the public schools as well. This dual burden led Catholics and their supporters to obtain laws which provided that the State make availale to all students free transportation, books, supplies and like benefits. Similar laws, and cases opposing them, were being passed in other states and at the national level. The U.S. Supreme Court in fact approved textbooks for parochial schools, but in the 1962 Dickman case, the Oregon Supreme Court, relying upon the provisions of the Oregon Constitution, said that this was an impermissible benef it to religion.

In 1961 and 1962, the Oregon Constitutional Revision Commission sought to alter the Constitution explicitly to prohibit aid to Catholic schools, but faced such an uproar that the ACLU proposal was tabled. However, in a somewhat backdoor move, the Commission did propose a change in the language of Article I, Section 5, which would have provided that no state monies go to religion (a provision narrower than the existing words). Although that provision was not approved (the entire package failed to win enough support to go to the voters), those who sought to place it in the Constitution later found themselves on the courts and began actively to interpret the State 
Constitution to give this meaning to the unchanged words.

During the 1945 legislature, a released time law was passed, which required schools to allow students to attend religion classes. That law was approved by the Attorney General, but came under attack in the courts. In the 1960 Dilger case, the court, following the lead of the U.S. Supreme Court, approved released time.

In 1972, an Initiative was filed by Catholics. It sought to overturn the Dickman case and to replace the language of Article I, Section 5, with the language of the federal First Amendment, now because of Dickman perceived to be more protective of religious groups. That proposal failed to pass.

In 1973, Catholic defendants again sought to have the Court declare shared and released time arrangements constitutional. The Court rejected shared time, in which the premises of a Catholic school were dedicated to public school education part of the day, and parochial the rest. The Court held that since the school authorities determined who could at tend, the school could not be truly public. Released time was again upheld. The Court once again emphasized that the "student benefit theory" was rejected in Oregon.

In 1980-81, after Catholic students filed suit attacking a law which prevented them from participating in school athletics for a year after any transfer to or from a public school, the Appeals Court ruled against them.

Other cases along the way, usually paralleled at the national level, included attempts to have diocesan offices and the church newspaper of fice declared subject to state taxes, revival of the Garb Bill (though this time against Rajneeshees and Sikhs), and attempts to subject Catholic church operations to the labor laws and unemployment laws. In the background, antiCatholic posters were found in 1985 plastered to walls all over Portland. 
These alleged that the Vatican controlled TIME Magazine, NEWSWEEK, and other media and banks. 125 Anti-Catholic plays such as Sister Mary Ignatius Explains it all for You and Agnes of God, ${ }^{126}$ played to full audiences, and even "escaped nuns", now Lesbians, lectured to large groups at Portland State University with convent tales as lurid as Maria Monk.127

Were these cases not part of a much broader movement against churches, non-public schools and religious groups, Catholics might well believe they were being singled out.

\section{(2) Early Churches.}

When Oregon's early churches disputed among themselves, the courts largely took a hands-of $f$ position over the question of which group was entitled to control church assets and policy. In the 1888 Liggett case, the Court said that an unincorporated church could properly impose a trust upon a corporation to effect its will. In the Philomath College case in 1893, the Court adopted the American Rule that courts would not interfere in ecclesiastical disputes, although a reading of the case shows that the Court went to great lengths to examine which was the correct body. Mostly the courts used the church rules as their constitution, or comparable practices with the effect of bylaws or constitutions, as in the Andrews case in 1917 or the Banks case in 1946. These decisions effectively kept church cases of this sort out of the courts. The very few cases which did come up had to do with whether or not correct procedure was followed, just as with any other corporation, and did not purport to deal with church doctrines or doctrinal differences.

(3) CHRISTIAN SCIENTISTS. 128

When the Christian Scientists came to Oregon in the late 1800s and early 1900 s, they were, as elsewhere, met with opposition. 
But Oregon proved friendlier than other states. In Nebraska, in 1894, a Christian Science practicioner named Ezra Buswell was acquitted by a trial court of violating the law regulating medical practicioners. The Nebraska Supreme Court held to the contrary and even cited scripture to find him guilty of simony, selling the gift of the spirit for money. In 1900, it reaffirmed this position in another case. Only in 1921, after numerous failed attempts, did the legislature change the law to exempt religious practicioners (so long as they did not use medicines).

In 1900 , the medical profession in Oregon successfully sought to have a Christian Scientist practitioner criminally prosecuted for practicing medicine without a license. A gravely ill woman had been treated by many doctors, but all had given up on her. She then sought Christian Science treatment, but she died. The Christian Scientist was first found guilty before a Justice of the Peace Court jury, but on appeal to the Circuit Court in Clackamas County was retried and found not guilty. The Scientists wisely defended by stressing not so much the scientific aspect of their beliefs, but the social prominence of their members and supporters. They were quick, through the Christian Science Monitor, and through members from aristocratic positions in society, to become accepted.129 This case was judged for Oregon a rare instance of judicial harassment. The laws were later changed to protect religious healing practices. 130

Over the years Christian Scientists continued, however, to have problems with doctors and hospitals on such questions as drug and blood transfusion refusal. But they have been largely successful because they have well-organized and professional backup out of central headquarters in Boston, which stresses the scientific and legal support for their views and which shows to physicians that there are alternatives, such as plasma, which are acceptable 
in most cases. The Christian Scientists, like the Unitarians, found quick social acceptability the key to relative acceptance to the world of mainline churches. The eminence of the internationally respected Monitor played no small part in this transformation. ${ }^{131}$

In two cases, Poe in 1933 and Estabrook in 1939, the Supreme Court accorded protection to Scientists. In Poe, it held that a gift to The Monitor was religious and therefore tax-exempt. In Estabrook it was held reversible error to allow inquiry into a witness's belief in Christian Science.

\section{(4) THB PEACE CHURCHES.132}

Members of the so-called "peace churches" -- Quakers, Amish, Mennonites, Hutterites, Brethren, etc. -- (Jehovah's Witnesses are treated separately below) perenially collide with the State because of their refusal to bear arms or participate in the wider society. Two areas of collision have been especially evident in Oregon.

(1) Pacifistic beliefs in America tend to be respected in times of peace, but not in times of war. Our courts distinguish between religious beliefs and action, but our public seems at times to believe that one is entitled to the beliefs only. World War I, which nearly everyone at first opposed, became a moral crusade once the U.S. entered. Those who held back, whether for religious, ethnic or political reasons, were subjected to ridicule and at tack, ranging from loss of jobs to deportation or imprisonment.

Article $\mathrm{X}$, Section 2 of the Oregon Constitution, not cited in any reported court decision, allows conscientious objection. It provides that "Persons whose religious tenets, or conscientious scruples forbid them to bear arms shall not be compelled to do so." Originally it excused only in time of peace, but was amended to its present form in 1962.

The Quakers in Oregon have been almost entirely conservative 
evangelicals, who withdrew from fellowship with more political Ouakers. Most were Republicans. During World War I many were placed in prison for refusal to enter the military. The 1922 Yearly Meeting adopted a resolution calling for release "of all C.O.'s who were being held as "political prisoners" ". 133

By the time of World War II, the pacifistic churches and the military, with more experience of each other, generally handled alternative service smoothly for recognized conscientious objectors.

By the eve of World War II, imprisonment was unsual. In $194564.5 \%$ of young men of the Oregon Yearly Meeting were registered as combatants, and $35.5 \%$ as conscientious objectors (serving in noncombatant service or civilian Public Service camps). In only one case, Pacific College professor Edwin Sanders, who refused to register at all, did imprisonment result.134 By the time of the Vietnam War, Oregon Quakers avoided identification with non-evangelical Quakers who actively dissented, 135 including separation from affiliation with the secular American Friends Service Committee. The Conscription Act of 1940 was written in consultation with the Historic Peace Churches and provided for civilian public service for conscientious objectors. 136

(2) The German churches and associations, especially during WW I, were under extreme social and legal pressure, which fundamentally altered their shape. Laws were passsed all over the country forbidding use of the German language. Many churches and associations gave up or substantially reduced German language usage. Lutheran churches, strongly national in character and with usually strong Germanic flavor, especially felt this pressure. In 1916, irate citizens filed a petition to close the Lutheran School at Sheridan. "The Lutheran School officials took the case to a federal judge in Portland who ruled that the school was in no danger and promised it protection." $137 \mathrm{~A} 1919$ 
Oregon Law prohibited teaching in language other than English. The Lutheran School Board suspected this law was unconstitutional, but forbade any congregation from making it a test case before it consulted with the Synodical School Commission. ${ }^{138}$ The Oregon School Bill contained provisions which effectively prohibited teaching of school in German and outlawed church schools where national or ethnic separation could be taught. The Lutherans therefore became active opponents of the Bill, working, as did the 7 th Day Adventists, with the Catholics, their traditional rivals.

(5) JRHOVAH'S WITNESSES. 139

The Witnesses came into legal prominence in Oregon and the U.S. in the 1930's. Their aggressive on-street and door-to-door proselytising led all over the country to many arrests. Witnesses often played records or distributed materials extremely offensive to Catholics and other religious groups. They were arrested for violating noise laws, for disturbing the peace, soliciting without a license, contributing to delinquency of minors, violating child labor laws, refusing to submit to the draft or to take oaths or pledges of allegiance, or become recognized conscientious objectors. Their sense of separateness and litigiousness (Courts being the one part of the State they did not disdain to use) led them to find prejudice where it may not have existed. 140

The leading cases involving a Witness refusing to participate in the pledge of allegiance or take oaths were decided at the national level. Local instances occurred in Oregon, where they were addressed by Attorney General Opinions, based upon the U.S. Supreme Court decisions. These at first allowed oaths to be required, and then forbade.

In Oregon, especially in World War II when their presence was more pronounced, Witnesses went to jail in large numbers for refusing to serve in 
the military. Unlike the Quakers, they would refuse to register or do alternative service. 141

The leading Oregon case, and for many years the leading case in Oregon Constitutional law on religion, was occasioned by a Witness who was arrested for having his children distribute literature and solicit on the streets of Portland. In 1944, the Oregon Supreme Court, in the case of Thornton v City of Portland, decided that the city could reasonably regulate religious practices and prevent a Witness from using his 14 year old child to solicit on the public streets.

The U.S. Supreme Court had just decided the case of Prince v Massachusetts, which allowed the State to prohibit using children for such work. The Oregon Court adopted that ruling. It held that, although they were expressed in different words, the federal and Oregon Constitutional provisions on religion had the same meaning (That continued to be the firm position of Oregon Courts until 1985, with the exception of the Dickman decision and the second decision in the Cross Case. In 1985 in the Salem Academy case, the Justices, led by Justice Linde who had been on the Constitutional Revision Commission and been a longtime advocate of State's independently interpreting their own constitutional provisions, reasserted that the Oregon Constitution was understood by them to be now narrower than the federal).

The federal decisions, Cantwell, Barnette, etc., established the legal right of the Witnesses to solicit on the streets and from door-to-door, and to attend schools but decline to pledge allegiance. Those decisions were followed by state legal authorities. In 1940, after the first flag salute case in which Justice Frankfurter had eloquently ruled that Witnesses could be required to do the flag salute, the Oregon Attorney General wrote an opinion 
which concurred.

(6) JEWS. 142

Little express legal discrimination against Jews has existed in Oregon. Private discrimination did exist, although Jews could be heard to say they had never encountered it. Still, such figures as Federal Judge Gus Solomon have said they encountered prejudice, in his case inability to find a law job with any firm in town or get admitted to Gentiles-only clubs. Religious discrimination was declared against state public policy and contrary to law in employment and public accommodations in 1949. But this only identifies one of the problems in analysing church-state relations or religious prejudice and law. Prejudice is no less existent when it is done by private individuals and the State declines to intervene or forbid. One could not have said there was no legal discrimination against Negroes because the law would not recognize them if they complained.

Jews have been successful and important businessmen, civic leaders and politicians in Oregon. In the 19th century, German Jews were leading merchants and community leaders. This pattern of successful participation has continued in this century. Julius Meier became Governor in 1929, Gus Solomon became federal judge in 1949, and Neil Goldschmidt, former Mayor of Portland in the 1960s and Secretary of Transportation under President Carter, is a serious candidate for Oregon Governor in 1985.

The 1949 State laws, and the 1964 federal Civi Rights Act 143 and Executive Orders made public religious discrimination illegal, but did not reach private discrimination. In this sense, the 1954 Snodgrass case represented a legal setback for all religious groups.

The late 1970 s and 1980 s have seen a resurgence of Neo-Nazi and ultra-patriotic, anti-semitic behavior and groups in the U.S., including Oregon. 
Incidents of painting of swasticas and vandalism of synagogues have occured in Portland and surrounding areas. These incidents, combined with Klan-type cross burnings and other racial problems, led the 1981 and 1983 legislatures to make racial and religious intimidation both misdemeanor and felony crimes. On these laws, portions of the black and Jewish communities were opposed by the ACLU, which was concerned with the restrictions on speech and thought in what it thought a poorly drafted bill. The Anti-Defamation League, strongly supported the law. These concerns led to adjustment of the laws in 1983 to meet ACLU concerns.

The presence, in Portland at least, of a strong Jewish presence since the 1880s, has placed a check on overt prejudice, but not successfully placed a check on private or anonymous behavior and opinion. Jews have been founders and leaders of the ACLU, including federal Judge Solomon, Attorneys Leo Levenson, Paul Meyer, Court of Appeals Judge Jonathan Neuman, and many others. Their concern for religious liberty and non-establishment has led them to play a forceful role in attacking bigotry or perceived establishment.

(7) THE INTERNATIONAL SOCIETY FOR KRISHNA CONSCIOUSNESS ("HARE KRISHNAS"). 144

The ISKC, known derisively as the "Hare Krishnas" because of their on-street chant (to the tune of "You Are My Sunshine") as they solicit passersby, came to Oregon as part of the 1960's counter-culture trend towards Eastern and quasi-Eastern religions. In Oregon as elsewhere, ISKA members, practicing a communal life, shaving their heads, wearing robes, aggressively soliciting on street corners and in airports and public places, living poorly, ran into legal problems. They were harassed and made to move on by police. They were arrested for solicitation without a license. The state conducted investigations into the raising of their children, and in some cases seized 
children and removed them permanently because of alleged "inadequate care", which often seemed to mean placing them in other than a Christian atmosphere.

In many cases, low level harassment was effective. In others, ISKAs were able to turn to free legal groups like ACLU and Legal Aid. Because the case law developed by the Witnesses on street soliciting and speech has been clear since the $1940 \mathrm{~s}$, usually intervention by a lawyer was all that was needed. Custody cases, however, with their resolution founded in discretion vested in judges who must assess individual facts and equities, usually were resolved on a non-religious basis on paper, though religion was clearly a factor and often the determining one.

Parents and relatives also used the police and the courts, either to obtain help in seizing their children for "deprogramming", or to defend their actions in the courts. Most of these cases fizzled out, as the parties evaded jurisdiction once they were physically free of a court's jurisdiction. Most courts were pleased to be free of the problems, and allowed cases to be dismissed.

In 1979, a Portland lawyer, aided by a Marion County Circuit Judge, obtained an ex Parte order which allowed him to seize his clients' son at the Portland airport. The son was promptly removed from the state for deprogramming. Although the press and the Judge expressed concern, the case was allowed to drop. ISKC in turn sued the parents, but also allowed its case to drop.

One ISKA case, Leyda $v$ Henrich Associates, reached the Oregon Supreme Court. Brought by Portland's free Legal Aid program, it held, based upon the recent decision of the U.S. Supreme Court in Lloyd $v$ Tanner, from Oregon, that the federal First Amendment did not compel privately owned 
shopping centers to allow access to private parties to solicit on their property. ACLU subsequently has sought to obtain a different result in the legislature, but has not succeeded to date.

(8) ETHNIC CHURCHES. ${ }^{145}$

Some of the Ethnic Churches, especially those which adhere to older ways, and including some of the Peace Churches, have been subject to investigation, by the State Childrens Services Division, of their child rearing and educational practices. The burden of such investigation and even prosecution has been heavy in some cases, with school authorities using the public prosecutors to assist. In 1978, a family of Russian Old Believers in Marion County faced criminal and civil prosecution for refusing to place their children in public schools. The parents believed that those schools undermined their religious beliefs. Misdemeanor and contempt prosecutions were brought against them. They were continually and very publically theatened not only with jail but with loss of their children. Finally they left the State, 146 and fled to Alaska.

Although the U.S. Supreme Court, in the Yoder case, gave constitutional protection to the separatist ways of the Amish, most states including Oregon have not been very respectful of the decision and have been slow to apply it. Home teaching is allowed in Oregon, but only with the permission of the local school superintendent. This has meant in practice that permission would be granted on a haphazard basis. Christians and Old Believers have complained that permission comes less often and with more difficulty to them than to "hippies" or more secular parents. Whatever the facts, the perception is real and reinforced by the discretionary nature, local option and standardless application of the law.

Oregon has a strong and visible population of Old Russians, and a solid 
core of Menonites and Quakers. These are usually solid citizens, rural and agricultural, with strong family life. Just as firmly and openly however, they decline to be part of modern life, and some find themselves in opposition to traffic laws, children's services, the schools, and the federal government's selective service and tax laws. 147

\section{(9) THE CHURCH OF SCIENTOLOGY.}

The Church of Scientology has had a Portland presence since the mid1970s. It has operated a very viable downtown school, and several other locations, including a foundation school in Sheridan. It has been under attack and criticism for many years. Critics have said that it was a cult, a fraud, which brainwashed its adherents and subjected them to such pressures that they could not leave. As a result, Scientologists have been one of the groups subject to parental seizures for "deprogramming". Police and court-aided seizures have been common around the country, and have led Scientologists to adopt defensive measures which sometimes seemed to justify the original complaints. Several prominent cases have been in the courts and in headlines involving the Church.

In 1981, the first Christofferson case was filed in the court and in the headlines. Julie Christofferson, a young woman from Utah, came to Portland and freely joined the Church of Scientology. She took a number of their courses in Portland and in Sheridan, but left voluntarily upon advice of the Church because her parents were objecting. She then sued and, after jury trial, obtained a multi-million dollar verdict against the Church. That judgment was reversed upon appeal, because it was ruled improper to allow inquiry into whether or not religious beliefs were sincerely held.

On retrial, in $1984-85$, a second jury again awarded multi-million dollar damages. It was clear that both government and Scientologists had engaged in 
reprehensible practices, though not necessarily to Christofferson. The Scientologists engaged in major rallies and information distribution campaigns, alleging that the federal government in Oregon and elsewhere has been persecuting them. On motion for new trial, the judge vacated the jury's verdict, stating that prejudicial religious argument by Christofferson's lawyer had rendered it invalid. For five weeks of the trial, the plaintiff was not mentioned at all, only the Church of Scientology. Interestingly, Mark Hopper, lobbyist for the Scientologists, was one of the sponsors of the 1981 racial and religious intimidation law.

(10) THE WORLD CHORCH FOR THE UNIFICATION OF CHRISTIANITY (THE "MOONIES"). 148

The Unification Church has had a presence in Oregon since 1979. It has been most evident, not for having on-site residency here, but for its moving from state to state of solicitation teams of young, attractive men and women who canvassed streets, homes, airports, and other public places seeking donations in return for flowers, publications, candy and the like. The Church rarely provided legal guidance or support for its soliciting teams, which often ran into legal problems, arrests, harassment, and investigations.

The "Moonies", as they are often derisively called, after their founder and leader Sun Yung Moon (who has recently served time in federal prison for tax evasion, in a case which recruited to his side prominent religious leaders and groups such as the National Council of Churches and Laurence Tribe of Harvard Law School), also actively participate in local charitable enterprises, and have been noted for starting their own church-run businesses and for living in communal centers. Oregon has been a site of their solicitation visits, but not until recently has it been a place of settlement. Presently there exists a community doing foodbank and other community service work in 
Portland. While concerns have been expressed, there is little current evidence of interaction with the law.

In other parts of the country, "Moonies" have been subject to regular intervention by the courts to seize children, where one parent has become a "Moonie", or to assist in kidnapping and deprogramming, or to resist the same. In 1979 appeared Hostage to Heaven, an account by Portland mother (and former Oregon ACLU staff person) Betty Underwood of how she rescued her daughter from the Unification Church through a traumatic lawsuit in California.

Portland is national headquarters for a data-gathering service on cults, run by Adrian Greek and his wife. Although they do not practice deprogramming, they keep tabs on "cults" and assist parents to be in touch with others who can assist them to rescue their children from the "Moonies" and similar groups. The Greeks believe the Moonies and similar groups prey upon the young and troubled, or idealistic, and place them under such psychological stress and coercion that they cannot retain their individuality or think for themselves. Two of their own children joined the Moonies. Their son joined in 1976 and induced their daughter, who is still a member in 1985, to join. The Greeks obtained an Oregon court order, and obtained custody of the son who, after time with them, requested that the judge continue the order for his own protection. In another case a girl was seized in Oregon based upon a Washington Court order. The Unification Church objected, and obtained her release with a promise she would appear for hearing. However she failed to appear. The Unification Church has been somewhat quiescent in Oregon since, in the 1984 Robin George case in California, a jury assessed damages of $\$ 39$ million against them because they forcibly kept custody of a minor. That decision, on appeal, has tied up their assets and forced closing of 
the temple in Portland. The Foodbank, began in 1985, is very low key in its operations and avoids public identification with the Church.

\section{(11) THE BHAGWAN SHREE RANNEESH AND HIS FOLLOWERS} ("RANNEESHEES"). 149

At this time, Oregon is best known to many in the world as the home of the Bhagwan and the Rajneeshees, who have "taken over the State". The ongoing saga of the Bhagwan and his followers has dominated headlines and filled courts and hearing agencies since 1981 when they purchased the Big Muddy Range in Wasco County. Their story is a subject for many books, some of which have been written. The Rajneeshees have been involved in over 200 legal encounters with courts and administrative agencies since their arrival, some initiated by them, some by their opponents. The federal immigration service has initiated mass proceedings to deport hundreds of Rajneeshee couples, and the Bhagwan himself. These proceedings have included such irregularities as scheduling dozens of interviews for the same time, and long delays in handling cases. The outrageous behavior of the Rajneeshees' opponents seemed to be matched at each stage by the Rajneeshees themselves, who sue and counter sue, employ a language more suitable to Oregon's early more robust days, and make soap opera moves such as the discovery that the Bhagwan was the child of an American citizen, and development of a homeless program. The 1000 Friends of Oregon has been the main mover against the Rajneeshees, and has supported ranchers who wanted to prevent settlement and development by the Rajneeshees.

The situation of the Rajneeshees well illustrates one of the problems in analysing church-state problems. Most of the cases on their face have no relation to the religion and practices of the group, but it is general knowledge that the religion and practices are a major factor in all of them. 
1000 Friends, joined by the Land Conservation Development Commission (LCDC), is lead party in the major lawsuits which seek to have the incorporation of the Rajneespuram declared invalid, based upon a law which was passed only after the incorporation. That case has been $t$ wice before the Oregon Supreme Court, which each time has remanded for further proceedings. The major clear religion case against them was preceded by an ex parte opinion of the Attorney General which stated, based upon assumed facts, that the city had no legal right to exist. The Attorney General filed in State Court to have the city declared unconstitutional. The Rajneeshees had the case removed to federal court, and it has bounced back and for th since.

Ranchers and the other activists have filed libel suits against the Bhagwan and his lead followers, and they in turn have countersued. The Bhagwan, who had been under a vow of silence, was subpoenaed for deposition, and the question of whether his vow was entitled to religious protection by the courts was raised and settled against the Bhagwan, after unsuccessful appeals all the way to the U.S. Supreme Court.

The Superintendent of Education has several times investigated the Rajneeshees, questioned them under the Garb Bill, declared their school without walls (where students work part of the day in the community and therefore in a religious environment) unconstitutional so that he withheld State funds, and generally made them work for each step of development.

The Attorney General and 1000 Friends have, now that battle is joined, used many tactics: special investigations, ex parte withholdings of school and road funds, public attacks, instructions to state departments to harass Rajneeshees in every way. Religion may not be the sole factor, but is clearly a major one in these proceedings.

A detailed account of the Rajneeshees' religion has been prepared by 
Professor Ronald Clark under the Oregon Commission for the Humanities, and a detailed calendar of events since their arrival, including a listing of cases and proceedings, has been compiled by Professors Ted and Carey Shay.

\section{(12) PROTESTANTS AND OTHER "MAJORITIES".}

One person's rights become another person's duties. When one gains, another must lose. Rights given are rights taken away.

Curiously, though logically, fundamentalist Protestants increasingly see themselves as a minority, or even majority, under persecution. They see the decisions removing religion and Bible reading, prayer and creches, from public life and the schools as successful attacks upon them and their beliefs by secular humanists and extreme separationists such as the ACLU.

They are dismayed to find that the history of the country is disregarded, and that the beliefs and wishes of the majority must be excluded from the schools and public places. They are told they must respect the rights of minorities, but have come to believe that their own rights are not respected.

This is well illustrated by the question of prayer or Bible reading in the schools, a practice as old as the schools themselves. A practice which they see as beneficial at worst, and harmless to any dissenter, is under firm attack whenever discovered. The will to root out any such practice appalls them as much as the success of the efforts. The Attorney General has ruled that Gideon Bibles cannot be given free to students even when done by private parties with the students' consent. Courts have ruled, with inconsistent logic and poor history, that there can be prayer in Congress and in the Courts, but not in the schools. One student, or two, has been permitted to nullify the practices and wishes of whole communities.

When these parents have turned to private schools or home schooling, 
they have again found themselves under attack. Benefits to students who are in religious schools have been attacked and prevented by the courts, whether transportation, books, or tuition, whether grade school, high school, or colleges. While huge benefits have gone to public schools, the private schools have been placed at a tremendous disadvantage. Similarly, home schooling has been under increasing attack, ${ }^{150}$ with the teachers' unions and ACLU leading the attack, as they have led the attack on tuition credits, voucher systems, and other devices meant to restore some tax equity for parents wishing to place children in teaching situations outside the public schools.

Just as the Courts seemed to have reversed settled law, and suddenly and arbitrarily created new law on prayer and aid to students, so court rulings on abortion and obscenity seem to fundamentalists to have reversed the positions of society on moral and religious questions. The State no longer prevents or prosecutes many previously prohibited practices, but now either enshrines them with legal protection, (as it does abortion and nude dancing,) or suggests it may soon do so (as with prostitution). The State, at one time the protector of moral values, is now seem to have gone over to the other side. Its vaunted neutrality is a neutrality against.

\section{(13) SEVENTH DAY ADVENTISTS.}

The Seventh Day Adventists, who keep Saturday (the Sabbath) holy, and who decline to take oaths, run into problems in both employment and situations where oaths (upheld by law in many situations) are required. Federal law and federal and state statutes in recent years have sought to provide accommodation where possible, as in the lead case of Sherbet $\mathbf{v}$ Verner, where the U.S. Supreme Court held that an Adventist could not be denied unemployment because he would not work on Saturday.

In Oregon, cases have arisen in several situations. In one, an 
Adventist was unable at first to work for a federal agency because he could not take the oath, which the law required for the position. The agency was willing to hire, but bound by the law. Careful research found court interpretations which allowed the parties to design an oath free of mental reservation. 151

In the 1981 Tooley case, the 9th Circuit Court of Appeals held that federal law which allowed a dissenter to give money to charity in lieu of union dues was not a violation of the establishment clause. Oregon has a similar statute, which the unions have also sought to invalidate in the legislature. The federal law is clear, but has not prevented problems of accommodation occuring in private employment.

\section{(14), OTHER GROUPS AND CASES.}

The above are the major Oregon minority religious groups, but the list goes on and on. Discrimination against gypsies is common, as they are subject to arrest and harassment. An ordinance in Roseburg was declared invalid as an improper restriction on the content of speech when it forbade fortune telling (by gypsies). Beaverton considered but did not pass a similar ordinance. Ashland has a similar ordinance which, in spite of an ACLU demand, it has refused to repeal. Indians and Orientals, such as Japanese and Chinese, have suffered massive discrimination which at times has had a religious component, as the groups were not deemed to have true or real religions worthy of protection or respect. Groups such as the Black Muslims, or the Native American Church, have had to fight to win equal protection for their services, whether in the community or in prison, where so often members of these groups have found themselves. As church groups have become active in politics on behalf of or opposed to abortion, obscenity, free speech, and homosexuality, they have been vigorously attacked by other church groups who 
claimed the activists were behaving illegally and that tax exemptions at least should be withdrawn. In America, people fragment into so many religous groups, that many are hardly ever even noticed and are lit tle known. The Sikhs, a major religion in India, were largely unknown in Oregon until a Sikh school teacher was fired for wearing her white turban, under a law originally aimed at Catholic nuns, which now also threatens the red-clad Rajneeshees. People in one group most often know little or nothing about other groups. Highly literate and informed people cannot tell what distinguishes Catholic from Methodist from Lutheran from Episcopalian, not to speak of the hundreds of other large and small churches. Many members, who appear to belong to this church or that for largely personal or social reasons, are of ten hard put to explain the beliefs of their own church. And indeed, some churches, such as the Unitarians, seem able to include anyone, even athiests and agnostics, within their churches. In such settings, churches become social habits more than associations of common believers in one faith. This trend has led observers such as Richard Morgan to predict it will mean a lessening of church-state tensions as a state of "ecumenical indifference" 152 is achieved. More likely, if history is a correct guide, new religious groups will introduce new conflicts, and the perennial Protestant-Catholic and religious-secularist conflicts will flare anew. 


\section{VIII - EDUCATION}

"no preference shall be given or discrimination shown on account of religious opinion, whether with the pupils or the teacher, nor shall any laws be enacted by any district that will or may in any way interfere with the rights of conscience in the free exerise of religious worship." 153

Apart from taxation of churches, the interrelation of church and state in education has seemed to produce the most conflict and emotion.

From the earliest days, disputes about education of Indians divided Protestant and Catholic. The Provisional and Territorial governments were both friendly to religion and stressed, in the words of the Northwest Ordinance, religion's necessary relation to education and good government. They saw religion as the necessary support for a just society. The Provisional Government also passed a law guaranteeing religious freedom in the public schools. (quoted above).

At the 1857 Constitutional Convention, its President Mat thew P. Deady spoke against having a State University (though he later was founder and became known as "father" of the University of Oregon), on the grounds that, as in Indiana, it would become in fact if not in theory a religious (Methodist) school. Deady also advocated that school funds be available to all groups to draw from, religious and non-religious.

In Oregon's first decades, public schools were few. The missionaries of Oregon played the major role in education, establishing a number of private religious schools, academies and colleges. These schools were the bases of the later state universities. But at that time, their existence delayed the beginning of widespread public schooling well into the 1880s. Many of Oregon's leaders indeed opposed having a public school system. ${ }^{154}$

Prominent leaders in public life often started in Oregon as teachers in these religious schools. Deady, for example, and Delazon Smith were both 
teachers in such schools. In both private and public schools regular use of the Bible, and the McGuffey Readers with their strong accent on prayer and the Bible, common employment of prayer in the schools, and belief in the U.S. as a Christian nation guided by God were the norm. 155 There was much animosity to Catholies and to Catholic Schools but not to religious teaching in the schools. Indeed, the schools were seen as the means to Americanize Catholics and minimize their influence. George Atkinson, American Home Missionary Society leader, who became Multnomah County (Portland) Superintendent of Schools, advocated the development of public schools to counter Catholic education. 156 When Catholics, gathered in 1884 for the Third Plenary Council in Baltimore, declared that within two years a parochial school should be attached to every existing Catholic Church, it was taken as a declaration of war and separatism by many Protestants and by such groups as the American Protective Association. The rise of the influence and numbers of the Catholic Church during the post-Civil War period led to much of the animosity of this period.

The Grant Administration, as evidenced by the Blaine Amendment, was very unfriendly to Catholies. 157 By the 1870 s, the Catholies had more Indians under their charge than any other denomination. The receipt of public monies by Catholics aroused the ire of anti-Catholic groups. The Grant administration developed a "peace plan", under which all denominational schools among Indians received public funds, which continued to the close of the century.158 The Catholics also, in the famous Poughkeepsie, or FaribaultStilwater Plan, experimented with a compromise where secular education in parochial schools would be paid for by public authorities and subject to their scrutiny, but this approach aroused so much hostility it was terminated. Within Oregon, as elsewhere, this dispute about which church would operate 
Indian schools divided the community.

As public schools developed in the latter two decades of the century, religion was a common part of the practices of both Catholic and Protestant communities. Although efforts were made to keep these practices nondenominational, all concurred in believing that religious practices properly underlay education and training for good citizenship. But the various sects would on occasion jealously watch to ensure that no one belief was advanced at the expense of others. 159

In those rural areas where Catholics predominated, economic realities and convenience led many communities to combine public and parochial schools. Nuns in religious garb came to teach in the public schools in such Catholic communities as Sublimity, Mt. Angel, St. Paul, St. Louis, Roy and Verboort. ${ }^{160}$ In these communities this arrangement reflected the desires of all concerned and might have continued unnoticed and unobjected to for many more years had not the controversy over religion and education arisen in the 1922 election campaign. The ultimate passage of the Religous Garb Bill was a clear byproduct of the same agitation which led directly to the Oregon School Bill.

As Malcolm Clark wrote "All Catholics, and a heavy percentage of Protestants, wanted religious instruction in the schools", though they differed on what instruction. To Protestants, "the Bible and the Common Schools were the two stones of the mill that would grind Catholicity out of Catholies".161

In 1921 a law was passed forbidding religious instruction in the public schools. 162 But this was understood to prohibit only sectarian instruction, not Bible reading or related "non-denominational" practices.

The agitation, largely to limit Catholic influence, had little real effect until, in 1922, the Masons and the Klan, aided by Protestant ministers, advanced what became the Oregon School Bill. That Inititiative would have 
required that all children under sixteen attend public schools taught in the English language. The fight over the School Bill polarized Oregon. It was clearly aimed at Catholics, although it would also have affected Lutherans (who taught and worshipped in national languages such as German and Norwegian), Seventh Day Adventists, Jews and some others. But the ideal public school was still one in which God, Bible and flag were together part of the American heritage. The 1923 legislature passed the Garb Bill, which prohibited any teacher in a public school from wearing religious garb, under pain of immediate dismissal and loss of teaching certificate. That law imposed criminal penalities upon any school board member who did not enforce this law.

The Attorney General in 1923 issued an opinion that the Garb Bill allowed neither exceptions nor delay, nor did it allow nuns to teach in religious garb in public schools even to obtain their teaching certificates. 162 The Attorney General had already opined that transportation was for public school students only and not allowed for parochial students.

The opposition was not to religious practices, such as Bible reading, in the public schools, but to any concessions to the Catholics. In the 1920s and 1930s, it was universally agreed that the Bible and God were a proper and necessary part of public school education. Oregon in the 1920s, as did most other states, passed a law requiring Bible reading in the public schools. 164

In 1939, an Oregon Law Review article suggested that Bible reading in the public schools might violate the State Constitution. This suggestion confirmed by implication that the practice was common.

Some cases arose where municipalities or private parties sought to prevent the establishment of Catholic schools. In 1932, e.g., the Oregon Supreme Court, in the Roman Catholic Bishop case, ruled that the town of 
Baker, which had permitted public schools to be built, could not exclude Catholic schools.

As their number in Oregon grew, Catholics in the 1940 s were able to secure laws or interpretations which provided free textbooks and transportation to all Oregon students, including those in parochial schools. But the Oregon Attorney General, in a series of opinions, found such provisions valid only under very restrictive circumstances. He concluded that parochial students could use public school transport, but only if the bus line was already on that route and they were not displacing public school students. Similarly the Attorney General approved laws which allowed released time (where students were released early to attend religious instruction) so long as the religious instruction was off school premises and not during school hours. The released time law was approved by the Supreme Court in the 1960 Dilger case, but free textbooks were ruled in violation of the Oregon Constitution (not the federal Constitution) in the 1962 Dickman case, which was brought by the ACLU in conjunction with Leo Pfeffer. The ACLU in 1962 also sought to place a provision in the Oregon Constitution which would have expressly forbidden religion. That provision said:

"The public schools shall be forever free from sectarian control or influence, and no religious instruction, exercise or worship shall be part of the curriculum of any public school".165

The ACLU noted that "most state constitutions have specific prohibitions against religious instruction in the public schools," but Oregon did not. After intense opposition was directed at the Constitutional Revision Commission by Protestants ministers and groups, it declined to support this proposal. It did seek unsuccessfully to alter Article I, Section 5 in a way which would have achieved the same result.

During the late 1930s and early 1940s, the Jehovah's Witnesses' cases 
in Oregon and nationally were troubling the country. The children of Witnesses declined for religious reasons to participate in the pledge of allegiance and flag salute. When the U.S. Supreme Court first heard the matter, in the Gobitis case, Justice Frankfurter, a Jew, wrote an eloquent opinion which held that the schools could require and impose these practices. Within four years, however, the Court reversed itself and, in the Barnette case, held that freedom of religion protected the Witnesses from such imposition. In the interim, the Attorney General relied upon the U.S. Supreme Court and told Oregon schools they could impose the practice upon unwilling Witness children.

Attorney General opinions from the 1960s on advised that a number of common and pervasive practices were now illegal: distribution of Gideon Bibles, Bible reading, and prayer in the schools. These opinions usually relied upon U.S. Supreme Court cases, or state cases elsewhere. However within Oregon, these practices continued, and suits were not brought because complainants could not be found to bring them, or because the practices were temporarily discontinued after complaints.

In 1969, at the instigation of ACLU and of the Portland Public Schools, whose Board President was then Jonathan Neuman (a former ACLU activist and now Court of Appeals Judge), the State Department of Education adopted a Model Policy on Religion which recommended a wide range of separationist policies. 166 In Oregon, however, the Constitution gives much power to School Boards, in effect allowing local option. Attorney General opinions and advice from the Superintendent and Department of Education are advisory only and do not impose rules upon the locally autonomous schools. Stevie Remington of the ACLU has written that "...no one seems at all interested in enforcing or checking to see if they are followed even. If you 
question the system, you are rudely put aside." (Note on copy of Model Policy.) The lack of an enforcing mechanism has allowed policy to be one thing, and practice another. The 1985 law allowing withholding of school funds provides a mechanism for changing this condition, but it is the judgement of many that these provisions, passed to get at the Rajneeshees, will be seldom and arbitrarily used.

In the 1970s, Catholic schools in Milwaukie, Oregon came to an arrangement with the local school district which was in ef fect a resurrection of the Faribault-Stilwater plans of the 1880 s. $^{167}$ A portion of each day in the Catholic parochial school was set aside in which only secular subjects were taught in rooms devoid of any religious symbols. This "shared time" arrangement was declared invalid in the 1973 Fisher case, when the Supreme Court said that a school could not be truly public when the Church determined who could attend. The Court confirmed that released time was valid when of $f$ school premises. The Fisher case involved Catholic historian Father Lawrence Saalfeld. 168

In 1971, the Oregon legislature, after consultation with and approval by the ACLU, passed a law which allowed the State to pay monies to private colleges based upon the number of Oregon students attending. The purpose of the law was to provide financial support for private colleges, which the State believed contributed to the quality of education. Religious colleges were not excluded. By the 1980s, this program, operated by the State Scholarship Commission and known as the PESIC (Purchase of Educational Services from Independent Colleges) Program, provided nearly $\$ 3$ million to private colleges, including religious colleges such as Concordia, George Fox, Judson Baptist, Linfield, Marylhurst, Mt. Angel, Northwest Christian, Pacific, University of Portland and Western Baptist. Although ACLU had supported the law in 1971, 
in 1981 it sued the Scholarship Commission and the private colleges, seeking to have the program declared unconstitutional. In the course of pre-trial investigations, a law was found which would have required the schools to pay back all monies if they lost. Although the state and the colleges believed that they had a better than 50-50 chance of prevailing, the religious schools chose voluntarily to withdraw and the suit was dismissed.

In the $1980 \mathrm{~s}$, a series of well-publicized cases on law and religion dominated the headlines. In 1981, the Appeals Court ruled in Cooper $v$ the Oregon State Athletic Association that a one-year transfer rule, which required that most transfering students abstain from interscholastic sports for one year (to minimize recruiting abuses), did not violate religious freedoms when applied to parochial students. The Garb Bill was resurrected in 1984 to force the firing and license termination of a Sikh teacher in Eugene, whose religion required that she wear a white turban-like head covering during the day. On appeal, the State Superintendent of Schools appointed a former Supreme Court Judge Arno Denecke as hearing officer, and affirmed the penalty. Lawsuits were filed in both state and federal courts, but these were compromised and dismissed in 1985 when the teacher, then living in New Mexico, had her license restored on condition that she not return to Oregon. ACLU, after internal debate which led to its first statewide membership referendum, intervened in the State suit, supporting the law, but arguing for a lesser penalty. The legislature vacilated, but appeared ready to strike down the law, when the settlement was announced and the matter was dropped as moot. Of the wide range of lawsuits surrounding Rajneeshpuram, the educational area has also been subject of attack. The Rajneeshees, who wear red garb and a mala (picture of the Bhagwan on a chain around the neck) were closely examined, and chose not to wear the mala in class to avoid 
problems. The State intensely scrutinized their school operations and forced them to shut down an innovative "school without walls" program, where students spent part of the day working in the community, because the state deemed the community a religious one. A program that might have been acceptible in secular Portland was deemed not acceptable in religious Rajneeshpuram. The State first suspended State funding, then restored it after the program was halted.

In 1984, a Multmomah County Circuit Court, in a case now on appeal, held that it was a violation of the State and federal Consititutions to allow prayer at a public high school graduation exercise. The suit was brought by $A C L U$, which later in the year chose to honor the plaintiffs, along with the plaintiffs in the Eugene Cross Case (another ACLU case) with the MacNaughton Award, its highest honor.

Questions on education and religion have with increasing regularity come to the Attorney General and generated opinions on such diverse subjects as Bible use, transport of parochial school students, unpaid chaplains at state colleges and paid chaplains at the State Boys' school and prisons, requirements of Saturday attendance at the State Dental School, scientific creation theory and equal time, religious displays and equal access. The decisions went in different directions, as the Attorney General disapproved of proselytising, but approved equal access and information programs and displays or, in the case of coercive settings such as the prisons, held that free exercise required the State to provide paid religious services.

ACLU files for the period 1955-1985 show that religious assemblies, distribution of Gideon Bibles, Bible readings and prayers in school, nativity scenes, religious music, use of schools by churches, shared and released time questions, and a wide miscellany of other questions and problems were 
recurrent. Charles Hinkle, writing in the Oregonian in 1983,169 described numerous examples of violations in each area. Sectarian religious classes, he found, had been occurring in public schools in Alsea, Butte Creek and Newberg in 1978, 1980 and 1981. The reality--whatever the law--continued to be a strong pattern of religious practices in the public schools. Separationist groups, such as ACLU, considered these practices objectionable, but difficult to eradicate.

In seeking reasons for the increasing support of separationist positions by the Oregon courts, several factors emerge. The character of Oregon's judiciary began to change as the Democratic Party came into real existence in the 1950 s. 170 It was, at its core, led by Jewish and secular liberals, who could be expected to take strongly separationist positions and to be supportive of judicial activism. Some judges, such as O'Connell, were deemed by Catholic writers to be anti-Catholic, and were judicial activists as well. Others, like Linde (who had been an aide to Senator Richard Neuberger and clerk to U.S. Supreme Court Justice William O. Douglas) combined strong Democratic liberal, separationist and judicial activist qualities. The lead of the U.S. Supreme Court gave them an example and a rationale, as they achieved influence, for imposing their beliefs regardless of Oregon history or precedents.

As Tyack illustrates, lack of knowledge, or denial, of the Protestant permeation of school and public life enabled state actors and courts to assert that they were preventing change rather than making it. Since the school of judicial realism of the 1930 s, led by such as Jerome Frank, many judges have become precisely convinced that their role is to make law. That tendency has been especially strong among Democrats, and to some extent the rise of the influence of the Democratic Party coincides with the constitutional activism described in this paper. In a traditionally Republican state, this has often 
meant that the judiciary, whose peer group lay in the elites of the metropolitan areas and of the nation outside of Oregon, has worked for different goals than the state's citizens. 


\section{A CONFUSION OF ACTORS}

The multiplicity of both state and private actors in the regulation of religion makes clear that church-state policy is not just one policy.

In Oregon the federal Congress and many administrative agencies make rules which are enforeed, or not, by federal and state courts, federal and state administrative agencies, U.S. Attorneys, and independent administrative law judges. Within the state the legislature, courts, the Governor, the Attorney General, the Superintendent of Education, District Attorneys and School Boards all have independent constitutional authority to make and enforce laws, as do many local municipalities. Legislatively-established state administrative agencies also make and enforce rules. The reality of law is that even most lawyers do not know all those who make and enforce it.

In constitutional theory, the U.S. Supreme Court may have the final decision as to whether or not a policy is constitutional, but practically this means little. "God is in heaven, and the Czar is far away", goes an old Russian proverb. The Supreme Court is little closer. Only a few cases reach that Court. Many which do are effectively insulated from review because they fall within a range of discretion given some agency below which does not permit the Court to intervene. Even when the Court rules, as it has on Bible reading in the schools, its edicts are not necessarily enforced.

Even on the Supreme Court, U.S. or Oregon, there is no necessary uniformity. In its early days, the Oregon Supreme Court, like most state courts at their inceptions, was reluctant to challenge the constitutionality of any law. Those who wrote the Constitution still lived and many were serving in the legislatures or the courts. They were unimpressed by courts who might tell them what they had meant in writing the Constitution. Also, in those earlier days, courts mostly held to theories which said that they discovered 
and applied laws, not made them.

Since the 1940 s this has changed at the federal level, as a more active judiciary, with the Supreme Court leading the way through its incorporation theories 171 and creation of new constitutional rights, has transformed the federal role. State judges have come to follow, although more slowly because they are mostly elected and subject to check in a way that federal judges are not.

In Oregon, change of judges on the Supreme Court allowed activist judges like O'Connell, Goodwin and Linde opportunity to put their beliefs about changing the law into practice.

In the religion area, their first attempts failed. The Dickman case announced a divergent rule, but its principle of narrower state interpretation was not followed. The 1962 Constitutional Revision Commission failed. The Eugene Cross Case II was effectively overturned. Not until the 1985 Salem Academy case, which again stated the Oregon's Constitution was separate and more narrow than the federal Constitution, did Linde prevail on principle, although it remains to be seen whether this is a permanent or transitory shift. The Thornton rule, with aberrations, held for 40 years and still has a substantial following on the Court.

In 1961, Oregon created the Tax Court, in 1969 the Court of Appeals. Both have taken an active role on matters of law and religion, and have displayed a strongly separationist bent. Tax court decisions especially have been increasingly restrictive. The Court of Appeals has been dominated by judges who have been activists in applying the state constitution to invalidate laws and rules, and have also been separationist in religion.

Attorney General opinions are not "law" in the same sense as Supreme Court opinions. They are, however, of strong weight and guide state agencies, 
whom the Attorney General by law represents. In earlier years, before the proliferation of courts and administrative agencies at both state and federal levels, it meant more to be the state's chief law enforcement of ficer. Then an Attorney General opinion dominated the field, whereas today it is but another, though prominent, voice. To enforce his opinion, the Attorney General must sue in court like any other litigant. He is by law, however, the only lawyer whom state agencies may have, and thus he has real leverage over state agencies.

Private parties in our legal system have long been the key actors in church-state relations. They are the ones in our legal system who initiate complaints and set the machinery in motion. Our laws are not self-enforcing. It took the Masons to conceive and carry through the School Bill. It took the Catholics and private schools to file suit to test the Bill in Court. Today groups like ACLU are the prime actors in initiating religion cases.

Frank Sorauf has traced the importance of interest groups in the development of law and religion at the federal level. These include the National Council of Churches, the Baptist Joint Committee, Protestants and Other Americans United, ${ }^{172}$ the Religious Liberty Association (7th Day Adventists), the American Jewish Congress (with Leo Pfeffer), the American Jewish Committee, the Anti-Defamation League, the ACLU, and education groups such as the National Education Association. The Catholics and such Protestants as those connected with Christianity and Crisis have proved the major accommodationist forces. The same groups have been active in Oregon, with the same essential strategy. In most situations, the plaintiffs are prepared and choose their time to sue, while defendants are usually unprepared and have few resources to defend. 173

ACLU first established a presence in Oregon in the 1920's, when Roger 
Baldwin played a small role in the Pierce case. In 1955 it formally organized and has provided a sustained separationist presence ever since. As lobbyist and litigator, it has watched, warned, maneuvered and litigated to ensure that a strongly separationist view was presented. ACLU was the key actor in bringing the Dickman case, the Eugene Cross cases, the Fisher case, and just about every major case since. It proposed revision of the Constitution in 1962, and opposed it in 1972. It first approved and then fought PESIC. It drafted and then supported the Model Policy for Oregon Schools. At each legislature it has had a strong presence of one or more paid lobbyists and dozens of volunteer lawyers and professionals. Its statewide presence has made it an effective monitor and influence. It has also been the coordinator of outside groups, drawing the aid of the national ACLU or such helpers as Leo Pfeffer and Protestants and Other Americans in Dickman. It has done at least three conferences statewide which, altough purportedly neutral, have in conjunction with the Oregon State Bar and the Oregon Committee for the Humanities, presented and advanced separationist views. One almost needs an organization chart to follow the complexity of actors in law and religion. 


\section{X . STATE ENFORCEMENT OF MORALITY}

It is characteristic that most people do not see themselves as having value systems or cultures. Others do, but to a people it merely sees the world as it is. When a group enforces its values, it uses a wide range of methods, of which law is only one. When it enforces what it sees as universal values, it may not explicitly state that these values spring from religious beliefs rather than from a whole set of societal beliefs of which religion is but one expression. Abortion, e.g., may be condemned because killing is wrong for religious reasons, but not for reasons necessarily limited to religious reasons. In Western culture, many writers have asserted that its basic values can be derived from religion or from non-religious philosophy and ethics which have universal validity and which cross religious barriers. A people will not necessarily separate for itself which reasons motivate its enforcement of primary rules. At various times, those rules may be such givens that there is no need to make such a separation. Indeed, the effort will seem not merely unnecessary but inconceivable. Although various state court judges, constitutional authorities and even the U.S. Supreme Court have at times asserted that we are a Christian nation and that Christianity was necessarily or historically linked both to our common law and to our Constitutional law, since the 1940s at least the tendency has been to find not merely non-denominational but wholly secular bases for "Christian" values embedded in law.174

From Oregon's earliest days, its religious people were engaged in setting public policy. How could it be thought to have been otherwise, when a concerted missionary effort was one of the main factors in settling the area? It would not necessarily be correct to say of the original settlers that they sought to use the state to enjoin Christian beliefs. Rather, they held 
their moral principles to have universal application. We are mistaken if today we read back into those times a complexity of competing beliefs which may demand more distinctions today.

Both among themselves and toward the Indians, the early settlers sought to prevent the manufacture and distribution of alcohol. The territorial laws provided for close regulation of taverns and imposed Sunday closing on a wide range of businesses. Before there were legal avenues to impose such limitations, however, the same results were achieved informally. The churches maintained internal discipline and corrective bodies, 175 which imposed sanctions even to the extent of expulsion, which in a pioneer community could be a sentence of extreme hardship. Apart from church procedures, the settlers were quite capable of speaking frankly to of fending neighbors and setting them straight in a world where each depended on others. When Oregon became a state, these same formal and informal disciplinary devices were carried over. But as more settlers arrived and the society became larger and more complex, methods of societal discipline became more formalized and became embodied into laws.

Because one may say that laws are not always necessary for members of a religious body, it is precisely correct to say that laws are made to enforce moral rules upon others outside of a structure of belief. The Sunday closing laws were a means by a religious people of imposing their religious and moral beliefs upon the whole society, although it should be noted that there are secular justifications for many at first merely religious rules (although the religion may determine the peculiar form of the rule). Oregon adopted a wide range of laws on what today would be considered by many to be private moral or religious matters. 176

The first court test of the Sunday Closing (or Blue) Laws came in 
State $v$ Palmer in 1866. An Act of 1854 had prohibited Sabbath-breaking and regulated berrooms. When Salem was incorporated, a tavern owner was prosecuted and defended himself with a claim, not that the law was wrong or unconstitutional, but that it had been superceded by the law which incorporated Salem. The argument was that Salem, as a municipal entity, would have had to make its own Sunday Closing laws.

The Supreme Court denied the claim, noting that the statute has been in force for many years and that "many of fenders had been subject to its penalties". It should be noted that Methodists, for much of the Territory's early years the dominant religious group, have always been especially opposed to alcohol. 177

In 1902 the Court, in the Northrup case, said that the law prohibiting barbering on Sunday was constitutional. The court traced the history of the Sunday closing laws since the territorial statute of 1854 , and its permutations under the state of Oregon. 178 One argument against the law was that it violated freedom of contract and liberty under the U.S. Constitution. The Court said that all courts in the U.S. had found such limitations, allowing on Sunday only works of necessity or charity, were a proper protection of employees to insure a day of rest. The Court noted: "If not in conflict with the federal constitution, it is necessarily not in conflict with our own", indicating at that early date an unwillingness to read the State Constitution to provide more limits than the federal.179 Again in 1916 the federal court in Oregon, in the Brunswick case, upheld the Sunday closing law against an attack which said it violated the religious guarantees of the federal Constitution. The Court said that such matters were left exclusively to the States.

In November 1916, Oregon voters repealed the State's ancient closing 
law "which over the years had been largely unenforced". 180

During the early years many laws were passed and enforced which, though some today may claim impose religious belief, were either not thought to do so then, or, if so, deemed proper in a Christian nation. Examples are laws against abortion, sacrilege, obscenity, Sunday violations or advocacy of birth control. Perhaps the laws on adultery and divorce are properly considered in this category also.

The Methodists, beyond their concern for alcohol, were pre-eminently social reformers since the time of John Wesley himself. They sought through individual and group missionary effort, as determined as that of the Puritans, to create a good society and to rescue or discipline the poor and erring. The Social Gospel approach, which was dominant in the late 1800s and early 1900s, had always been true of them, but by the 1880 s had become true of many denominations. In Oregon, Methodists and others placed church support behind the movement for women's rights to vote and behind temperance. Indeed, part of the support for women's suffrage was to obtain the votes to impose temperance. Malcolm Clark's War on the Webfoot Saloon recounts a chapter in the temperance wars, when religious women encouraged by Protestant ministers courted arrest and jail to prevent the evils of alcohol. Biographies of leaders of the movement, such as Abigail Scott Duniway, share the same condemnation. 181

This crusade, however had a darker side, in that it set Protestant against Catholic. Senator Blaine, who aspired to the Presidency, found the slogan "Rum, Romanism, and Rebellion" attributed to him as a characterization of the opposing Democrats. The Catholics, urban and Irish to a large extent, were seen as agents of demon rum as well as Satan. 182

The American Protective Association, in its brief moment in Oregon, 
sought to use the laws to restrict Roman Catholics. It succeeded in getting anti-Catholics elected to school boards in Portland and elsewhere, but failed in an attempt to pass a law forbidding the Irish flag from being flown on public buildings on St. Patrick's Day. 183

Much of the animus against aliens, oriental and other, was based on their Catholicism or non-Christianity. The Spanish-American War was partly motivated by efforts to save Cuba and the Phillipines from the Pope. The exclusions of Chinese and Japenese were in part based upon their being nonChristians.

In the 1901 session, there was talk of a law to prohibit Christian Science in the State, but it never took formal form.

The Social Gospel movement produced in Oregon three church leaders of national prominence, who were successful in translating their religious and ethical concerns into law. Thomas Lamb Eliot, pastor of the Unitarian Church and with Reed College, created the Humane Society, established the juvenile court system and children's home, was superintendent of Portland's Public school system, and was for decades a leader in social reform, active in nearly every movement. (In later years, his Unitarian Church, under the leadership of E.B. MeNaughton and Charles Davis, both also ACLU leaders, continued to have strong influence in church-state policies.)

Edwin O'Hara, a Catholic priest from Wisconsin (where he fell under the influence of the labor priest Monsignor John Ryan), came to Portland and joined Rabbi Stephen Wise in successful efforts to enact protective labor laws in Oregon. O'Hara gave his name, as Commissioner of Labor, to the cases in which the U.S. Supreme Court upheld those laws. O'Hara was aiso the moving force in opposition to the School Bill. Rabbi Wise, before going on to the Free Synagogue in New York, worked with O'Hara and other progressives in 
Oregon on reform in labor laws, defense of working men and aliens, and respect for religious groups of all sorts.

During the First World War, nationality churches of German background, primarily Lutherans and Brethren who spoke German, were placed under tremendous pressures to Americanize. The patriotic societies swelled in membership after the War. Those such as the Orange lodges were traditionally anti-Catholic. Rome had condemned them at the turn of the century, as well as other secret societies formed to support democracy or unionism, and earned long-memoried enemies. When the Klan came to Oregon in 1921, it found its membership largely in patriotic societies, and part of its goal was to restrict Catholicism in its non-American or anti-American aspects. The School Bill, the Garb Bill, and attempted laws prohibiting sacramental wine and seeking to eliminate Columbus Day as a holiday, were prime examples. Less obvious were the use of local laws and national laws, to curb immigration or restrict aliens and labor, which allowed indiscriminate application against members of groups disfavored in part because of their religion.

A 1915 law was proposed which would have required inspection of all convents, monasteries, hospitals and like institutions both annually and upon petition of any twenty people. 184 The law was aimed at Catholic institutions to ensure that no un-American practices were going on in those institutions.

In 1917, the Oregon Constitution was amended, Article IX, Section 1, to delete language specifically exempting "religious" entities.

The ACLU, in its Annual Report for 1925-26, noted that Oregon had a law which required daily reading of the King James Bible in the school.

The School Bill from 1922-25 was defended by Governor, later Congressman, Walter Pierce, a lifelong anti-Catholic who was later a founding 
member of Protestant and Other Americans United for Separation of Church and State, a group which took its ideas from Paul Blanshard. 185 The biographies of both Pierce and his wife make clear the extreme antiCatholicism which motivated them.

The ACLU has had a presence in Oregon since the early 1920s, when William S. U'Ren and C.E.S. Wood were its local correspondents. Indeed, Roger Baldwin, ACLU's leader through most of its existence, had a small role in aiding the Catholics to find an appellate lawyer in the School Bill case. Many of ACLU's early leaders nationally, and later in Oregon, were ministers of Unitarian or Social Gospel types. During the 1950s, E.B. MacNaughton, also national moderator of the Unitarian Church, was on the National ACLU Board, indeed heading it for a while. When the Oregon affiliate formed in 1955, its leaders were Unitarians and Jewish Democrats, who strongly believed in separation of church and state. It was ACLU which filed the Dickman case, one of its earliest victories. Since that time, ACLU has been in Oregon the major policeman of church-state separation. Its constant efforts have opposed any religion in the schools and in public life. It has opposed public aid to religions, while at the same time defending religious groups against public intrusion or excessive public regulation.

When ACLU, however, seeks to advance its opposition to the death penalty, it allies with church leaders and marshalls their participation in politics. When it opposes aid to parochial schools, it marshalls in its camp representatives of liberal or separationist church groups such as Ecumenical Ministries or the Lutherans and Seventh Day Adventists.

Today, the State is a battleground on which separationist and accommodationist, church and anti-church forces compete to impose their will. Prohibitions once universally accepted (such as abortion) are now claimed to 
be but the religion of a few, improper to impose upon others. Regulation of obscenity, pornography or prostitution is opposed in part because it is said some seek to impose the religious beliefs of a few upon all. On the other hand, church groups oppose gay rights and ask the State to outlaw behavior of which they disapprove. In an age of relativism, once secure State policies are under attack, and are attacked and defended for religious reasons. 


\section{CONCLUSION}

Church-state relations in Oregon are, now as ever, in a state of turmoil. The conflict is built into Western culture and American history. Oregon has been no exception. The conflicting strands of extreme separationist and extreme accommodationalist approaches are met by pragmatic problem solvers in both community and court. The history has been one of accommodation here, and separation there, with an increasingly separationist trend.

What is impressive is how few cases of constitutional import were brought before the 1940s, and how many after. Also impressive is the sheer bulk of reported cases and opinions on religion, showing that management of the proper sphere of each is a problem susceptible of much interpretation and judgment.

It is difficult to define what a religion is. Americans find it as difficult to define orthodoxy as dissent. 186 When they believe something is wrong, they often proceed against it in an apparently non-religious way. Trespass or nuisance laws are invoked against Witnesses, truancy laws against Old Believers, and land use laws against Rajneeshees. A mere review of the records will not tell if criminals or religious dissidents are in the dock. The enforcement of morality will not tell us if criminals or religious dissidents are to be coerced. In an increasingly litigious society, those who wish to evade the law will become religious when it is a shield, whether to gamble or to sell good feeling.

Presently, the Oregon Courts are interpreting the Oregon Constitutional provisions separately and more strictly and separationist than the federal courts interpret the federal First Amendment. This has resulted and will 
likely result in more litigants using the Oregon Constitution as a sword against religious practices in the public arena.

Oregon historians, with their judgment that the state has been progressive and rational, concur that it has engaged in periodic instances of religious, racial, and color bigotry. However, events have not always been reducible to discrete legal cases. Intimidation by the Klan or mass evacuation of the Japanese have had religious components difficult to extract from the larger events. Consideration only of court cases must prove inadequate.

There is no sign that religion and law, church and state, will be less involved each with the other in years to come. The evidence is that the management of these relations requires continual adjustment. Even when pronouncements of law are made, the people do not necessarily submit. Biblereading and prayer in schools remain common practices although proscribed. Our legal system requires a complainant with standing, and many communities lack those who have the desire or will to object. The ACLU has been unable, however willing, to bring many a case because of lack of a suitable plaintiff. Only a few laws are self-activating or activated by public officials in the normal course. This lends a sporadic quality to enforcement, and allows a flexibility in the system which on paper it appears not to have. Local option has usually been the reality. 187 


\section{NOTES}

1. Everson v Board of Education, 330 U.S. 1, 16-18(1947).

2. Lemon v Kurtzman, 403 U.S. 602, 614(1971).

3. Robert Frost, Collected Poems, (Rinehart Press, San Francisco, 1963),23-24. With Frost's typical irony, he has his neighbor intone: "Good fences make good neighbors." But he himself asks: "Why?" and "Before I built a wall I'd ask to know/ What I was walling in or walling out/...."

4. Orville H. Zabel. God and Caesar in Nebraska-Church and State 1854-1954. (University of Nebraska. Studies \# 14. Lincoln, Nebraska. 1955), 2.

5. For excellent and concise summaries and analysis on the cases and trends in federal church-state law, see: Henry J. Abraham. Freedom and the Court: Civil Rights and Civil Liberties in the United States (4th Ed. Oxford University Press. New York. 1982); and Leonard F. Manning. The Law of Church-State Relations (West Publishing Company, St. Paul, Minn. 1981).

6. Sanford H. Cobb. The Rise of Religious Liberty in America (Macmillan and Co. New York. 1902).

7. Carl Zollman. American Church Law. (West Publishing Co. St. Paul, Minn. 1933).

8. Anson Phelps Stokes and Leo Pfeffer. Church and State in the United States. (Harper and Row. New York. 1964).

9. Charles James Antieu, Philip Mark Cande, and Thomas Arnold Burke. Religion Under the State Constitutions. (Central Book Co. New York. 1965). Conrad H. Moehlman. The American Constitutions and Religion. A Sourcebook on Church and State in the United States. (1938). The 1930 account of William W. Sweet, The Story of Religion in America (Harper and Row. New York. 1933) and the 1984 account of Martin Marty, Pilgrims in Their Own Land. 500 Years of Religion In America. (Penguin Books. New York. 1984) are worthy of mention. Sydney Ahlstrom's two volume 1975 work, A Religious History of the American People (Image Books. Doubleday and Company, Inc. Garden City, New York. 1975) is a splendid overview of church history in America with a thorough bibliography. These accounts, although not focused upon law, are reliable discussions which place the legal problems in context. They each reveal the predominance of the question of the right relationship between church and state.

10. Richard E. Morgan, The Politics of Religious Conflict: Church and State in America. (University Press of America. New York. 1968). Frank Sorauf, The Wall of Separation: The Constitutional Politics of Church and State.(Princeton University Press. 1976).

11. Leo Pfeffer is quoted by Richard Morgan, at 81 , as describing the struggle over the constitutional law of church and state as "associational jurisprudence." Morgan describes the litigants as "The professionals who make 
up the church-state attentive public," and refers to intra-state actors as "church-state amateurs" 94-95. Morgan has also written The Supreme Court and Religion (The Free Press. New York. 1972) which identifies the major academic critics of Supreme Court religion decisions. Sorauf describes in detail the legal actors in the church-state cases and their orchestrated strategies.

12. Alan L. Gallagher, The Oregon School Bill of 1922: A Reevaluation (M.A. Thesis. Corpus Christi State University. 1984) (Copies on file in libraries of Portland State University, University of Portland, and Oregon Historical Society).

13. Mark De Wolfe Howe, The Garden and the Wilderness: Religion and Government in American Constitutional History. (University of Chicago Press. 1965). The point, although Howe expresses it with particular eloquence, is unexceptionable. Cf. Zabel, 10. For a current expression, U.S. Secretary of Education William Bennett has said: "the fate of our democracy is intimately intertwined -- 'entangled', if you will -- with the vitality of the JudeoChristian tradition." Quoted in George F. Will, "Bennett right in line of American Tradition", The Oregonian, August 15, 1985. E9.

14. Among the best federal cases are the Supreme Court in Walz $\mathbf{v}$ Tax Commission, 397 U.S. 664 (1970), and the 1984 decision in Lynch $v$ Donnelly, where the court explores the historical understanding and practices of the people, remembering Holmes' aphorism from The Common Law that an ounce of experience is worth a pound of logic. A similar analysis was conducted by the Oregon Supreme Court in the first Eugene Cross Case. The author's view of the proper reading of the First Amendment is that of Michael Malbin, Robert Cord, Joseph McClellan, Justice William Rhenquist in dissent in Wallace v Jaffree, and the federal district court trial judge in the same case (see the bibliography for full citation).

15. This point, which underlies much of this work, is worth immediate attention, as general readers are too apt to accord to lawyers, courts and the law a deference which is undeserved. Howe, at 4, is pointed: "By superficial and purposive interpretations of the past, the Court has dishonored the arts of the historian and degraded the talents of the lawyer." Charles A. Miller, The Supreme Court and the Uses of History (Simon and Shuster, New York. 1969. 1972), analyses at some length both how and why courts and lawyers are so inclined. In the area of the religion cases, the Supreme Court and other courts have been especially poor. Illustrations abound, but the reader is referred to Robert L. Cord, Separation of Church and State: Historical Fact and Current Fiction (Lambeth Press. New York. 1982). Morgan describes the works of Leo Pfeffer as "an example of such purposeful history from a separationist viewpoint," at 143. See also such critics as Paul L.Murphy, The Constitution in Crisis Times 1918-1969 (Harper and Row, New York, 1972), 392, where he criticizes Justice Black for "poorly researched historical foundations" in the Engle case. Murphy refers to a more detailed critical analysis of the court's misuse of history in an article by himself in the American Historical Review (LXIX. Oct. 1963,) 64-65, "Time To Reclaim: The Current Challenge of American Constitutional History") and refers to a Commentary article of Leonard $W$. Levy to the same effect. The point is that it is difficult to find a serious historian who will defend the courts' use of history in the area of religion. Justice Renquist, dissenting in Wallace $v$ 
Jaffree, 105 S. Ct. 2479,2508 (1985), emphatically rejects the history of the court majority, finding it "demonstrably incorrect" and stating that "stare decisis may bind courts as to matters of law, but it cannot bind them as to matters of history."

16. Although the work of William Sweet, Robert Handy, Martin Marty, and Sydney Ahlstrom would seem to belie this point, examination of most standard histories, and those of Oregon, show that after the pre-Revolutionary period, it is usually largely ignored or relegated to a few references. Cf. the analysis of Wallace Farnham, Religion as an Influence in life and Thought: Jackson County, Oregon, 1860-1890 (Ph. D. Dissertation. University of Oregon. 1955).

17. Howe, 110, "the danger that an outlawed establishment may reappear in the disguise of a preferred liberty." Also P. 100.

18. "Toward a Constitutional Definition of Religion," Note, 91 Harvard Law Review 1056 (1978); Cf. Howe, $91 \mathrm{ff}$.

19. Zabel, 100-101, 184 .

20. Marty ix, "To put the name chaos on chaos is the first step in ordering." 320.

21. Deukmejian and Thompson, "All Sail and No Anchor", 6 Hastings Constitutional Law Quarterly 975 (1979).

22. "...neither was able to dominate the other completely, so that the duality persisted and was ... ultimately built into the structure of European Society. This situation profoundly influenced the development of Western constitutionalism. The very existence of two power structures competing for men's allegiance instead of only one compelling obedience greatly enhanced the possibilities for human freedom." Brian Tierney, The Crisis of Church and State 1050-1300 (Prentice Hall Inc. Englewood Cliffs, N.J. 1964), at 2. In this analysis, the "problem" of management has in fact been a creative tension with welcome results. Thus the "problem" admits of no desirable "solution".

23. Even in the 20th Century, former Justice William O. Douglas, could write: "We are a religious people, whose institutions presuppose a Supreme Being." Zorach v Clauson, 343 U.S. 306, 312-313 (1952).

24. Howe describes how the established churches, hierarchical in form and restricted in membership, came into conflict with communities of nonmembers who opposed paying taxes. In revolt, those communities successfully took over established churches, requiring governance by democratic vote. Some states went so far as to pass laws which allowed only churches of congregational form to exist.

25. Indeed many states passed laws which required churches to have a congregational form of governance. Their laws severely inhibited Catholics and Episcopalians, who in turn sought special legislation to accommodate their hierarchical needs. The development of the corporation sole (of one-personthe bishop), and of corporate structures which allowed a bishop to appoint a majority of trustees, eventually resolved the problem of control of church 
property which the congregational laws had stimulated. Cf. 19 A.G. 479 (1939).

\section{The Dalles v Missionary Society.}

27. It was one thing openly to call for common public schools and no religious preferment, but a candidate could not by open anti-Catholicism succeed in the face of the growing Catholic and Democratic Party population in the cities.

28. Donald Kinzer, The American Protective Association - An Episode in Anti-Catholicism. (University of Washington Press. Seattle. 1964).

29. John Higham, Strangers in the Land: Patterns of American Nativism 1860-1925 (Atheneum. New York. 1963).

30. Charles Carey. General History of Oregon (Binford and Mort. Portland, Oregon. 1971). Priscilla Knuth, Nativism in Oregon (Reed College Thesis. Portland, Oregon. 1947).

31. Carey, History, II, 499-503.

32. Malcolm Clark, "The Bigot Disclosed: Ninety years of Nativism, Oregon Historical Quarterly, LXII. (June 1974,) 109-182, at 138-140.

33. Ray Allen Billington, The Protestant Crusade 1800-1860: A Study in the Origins of American Nativism. (Macmillan. New York. 1938 (1952)), $99 \mathrm{ff}$.

34. George Williams was also a member of Oregon's Constitutional Convention. It was he who successfully moved the final form of what became Article I, Section 5.

35. Opinion Attorney General 1923.

36. Mejer v Nebraska, 262 U.S. 390 (1923)

37. However, in Pierce the federal First Amendment was neither invoked or thought to apply. Howe, at 124, emphasizes: "The striking failure of the Court to suggest that the religious enterprise of the Society of Sisters and religious liberty of the parents and children gave (them)....constitutional rights different in any respect from those of the Hill Military Academy".

38. Oregon had made Prohibition part of the State Constitution in 1916, but excepted sacramental wine. Art. I, Section 36.

39. Hans Linde, "First Things First, Rediscovering the State's Bill of Rights", 9 U Balt. L. Rev. 379 (1980).

1985).

40. Oregon State Bar, Oregon Constitutional Law (Portland, Oregon

41. "A Comparison of the Court's holding and its method of 
adjudication in Thornton, Dickman, Eugene Sand and Gravel, and Salem College shows that the prevailing fashion of adjudication in one decade may be scorned in the next." Charles Hinkle, Oregon State Bar, Chapter 2, p. 36.

42. 42 U.S.C.A. 2000 et seq.

43. No. 11246. There are current proposals to rescind this order.

44. The Equal Access Act of 1985, Title VIII of Public Law 98-377. Cf. Congressional Record, Oct. 11, 1984 (S 14473-76). The Commentary identifies current major federal actors in Church-State law.

\section{At 184 .}

46. At 246 .

47. See especially Charles Miller, and Howe. There is a solid academic constituency which condemns the Court's history and logic in the religion cases, including such as Dean Ervin, Edward S. Corwin, Walter Berns, Robert Drinan, Robert Cord, Michael Malbin, Francis O'Brien, and many others.

48. "Not only do traditional constitutional histories include a large number of atypical "great cases", but constitutional cases are also unrepresentative either as intellectual history or as an example of social control. Indeed, constitutional law in America represents episodic legal intervention butressed by a rhetorical tradition that is of ten an unreliable guide...." Morton Horwitz, The Transformation of American Law. 1780-1869 (Harvard University Press. Cambridge, Mass. 1977 (1981)), xii.

49. Edward S. Corwin, "The Supreme Court as a National School Board", in American Constitutional History (Harper and Row, New York. 1964), 213.Corwin's is the earliest and still the best critique of the Supreme Court's misadventures into religion and law. He succinctly and correctly reviews the history, scholarship and logic of the First and Fourteenth Amendments.

50. Edwin O'Hara, Catholic History of Oregon (Catholic Book Co. Portland, Oregon 1925), 109-110.

51. The Northwest Ordinance, with its requirement that land be set aside in each new state for public schools, is the basis of our public school system.

Carey, 336, 350, 689-699. Corwin, 197.

52. The records of that Convention are assembled in Charles Carey, The Oregon Constitution and Proceedings and Debetes of the Constitutional Convention of 1857 (State Printing Dept. Salem, Oregon 1926). However, the verbatim notes of the Convention were never transcribed, because of a reluctance to pay the costs, and have been lost.

53. Carey, 468. Sections, $2,3,4,5,6, \& 7$ were copied verbatim save for the section on no payment for religious services in the legislature (Sec. 5) and part of Sec. 6. 
54. Although this fact has not (yet) been accorded significance in the Oregon Courts. It was raised but once, in the Cross case. Howe notes, at 131, the "very striking tendency in all the many revisions of state constitutions which were effected in the postwar decades to include prohibitions against the use of public funds for the support of denominational schools." This was not the case in Oregon. The Blaine Amendment, with its express prohibition of aid to religious schools, is worth remembering here, as is the failed attempt to have the 1962 Oregon Constitutional Revision Commission adopt such a provision, sponsored by the American Civil Liberties Union (ACLU). Albert Warden, Baptists in Oregon (Judson Baptist College, 1969) does note, at 385 , "the passage of a state law in the early 1920 s forbidding religious instruction in the public schools." Cf note 165.

55. Carey, 119.

56. Carey, 301.

57. Patrick Malone, reporter for The Oregonian, took verbatim notes, but these were never transcribed and were subsequently lost. The proceedings were not printed until 1882, and that printing did not include the debates. The newspaper and memoir accounts of the Convention do not account for the loss and renumbering. Charles Hinkle calls it a "scrivener's error", but only to express lack of an explanation. It is hard to consider it a scrivener's error, when it resulted in renumbering. The Oregon Supreme Court has declined to accord any significance to this deletion, in the Eugene Cross Case, 254 Or. at 546-547.

58. Carey, 300 .

59. Carey, 335. Cf note 165.

60. The McGuffey Readers, published from 1836-1920, openly employed the essentials of Christian belief as a teaching tool. The Fifth Reader, e.g., had such sections as: "Respect for the Sabbath Rewarded", "Select Paragraphs" and "The Goodness of God" from the Bible, "Religion is the Only Basis of Society", "The Bible the Best of Classics", and "My Mother's Bible." Cf. Arthur H. Bone's Oregon Cattleman/Governor/Congressman. Memoirs and Times of Walter M. Pierce. (Oregon Historical Society. Portland, Oregon. 1981), where Pierce notes that the Readers were "in universal use" in Oregon schools. Pierce had been both school teacher and superintendent of schools in eastern Oregon.

61. David Tyack, "The Kingdom of God and the Common School: Protestant Missionaries and the Educational Awakening in the West" Harvard Educational Review, Vol. 36 (Fall 1966), 447-469, and "Bureaucracy and the Common School: The Experience of Portland, Oregon 1851-1913" American Quarterly Summer (1967) XIX, 475-498. "Almost all education is entrusted to the clergy." de Tocqueville, I, 320, Democracy in America.

62. James Schand, Garb Bill (unpublished. Portland, Oregon. 1985).

63. Nativism and anti-Catholicism in Oregon were largely ineffective. Knuth writes: "At no time after the period of missionary dominance did 
nativism have any considerable degree of success," at iii. "Nativistic intolerance in the United States between 1830 and 1900 achieved little in the way of legislative action," at 10. But she notes, at 125, that American Protective Association School Board directors in Portland in 1895 dismissed nine Catholic teachers. Malcolm Clark notes, at 142, that Oregon anti-Catholics were politically ineffective and, indeed, largely quiescent during the early years of the present century." Clark had access to the records, believed by Kinzer to be lost, of the American Protective Association in Oregon, 139-140, and concluded that its membership and strength in Oregon "has been badly overstated."

64. Cf. 18 Oregon Law Review 125 (1938), and the accounts of the schools in the Klan period of the 1920s by Saalfeld. Tyack had noted, at 486 , that in 1877 a school exercise was to "write and punctuate The Lord's Prayer". Zabel described the pervasiveness of such practices in Nebraska and, at 104, cited Stokes with approval that "it is believed that a majority of the schools in the country still open their daily sessions with reading without comment from the Bible," and "a substantial minority open with a hymn and The Lord's Prayer." He says that Zollman concluded that constitutional provisions against sectarian instruction were not aimed at Bible reading, and notes that the Blaine Amendment specifically excepted Bible reading from its prohibitions.

65. For a fuller account of the Oregon School Bill, the Klan, and writers upon them, see the sources and analysis of them in the author's The Oregon School Bill of 1922: A Reevaluation.

66. Letter to The Oregonian in April 1984 by Oregon Mason's Inspector General David O. Johnson, and personal communications to the author to the same effect. The Scottish Rite in 1948 provided the funding to start Protestants and Other Americans United for Separation of Church and State, an anti-Catholic group. Morgan, 60.

67. Cf. especially Gallagher; Steven Recken, A Reinterpretation of the Oregon School Bill of 1922: The Concept of the Common School in Progressive America (M.A. Thesis. Portland State University. Portland, Oregon 1973); and James Ziegler, Epilogue to Progressivism in Oregon: 1920-1924 (M.A. Thesis. University of Oregon, Eugene, Oregon 1958).

68. Cf. Mat thew Deady's Journal, Vol. I, p.100 and Clark's footnote 115 at Ill. Malcolm Clark, Pharisee Among the Philistines. Diary of Judge Matthew P. Deady. 1871-1892 (Oregon Historical Society. 1975. 2 volumes).

69. Clark, at 143-44, "The Bigot Disclosed".

70. "Escaped Nuns" are still common on today's lecture circuit, e.g. in 1985 lesbian ex-nuns appeared before large crowds at Portland State University to tout their book Lesbian Nuns. The Oregonian, June 16, 1985.

71. Such as Gordon Dodds, Oregon A Bicentennial History, (WW Norton \& Co. New York, 1977), and Dorothy Johansen and Charles M. Gates, Empire of the Columbia A History of the Pacific Northwest, 2nd edition (Harper and Row. New York. 1967). 
72. The phrase is Saalfeld's, 60.

73. 25 Opinion Attorney General 46 (1952). Oregon. 1962).

74. Report of the Oregon Constitutional Revision Commission (Salem,

75. Cf. Justice Hans Linde's celebratory article, "Chief Justice O'Connell's Contribution to Oregon Public Law," 56 Oregon Law Review 227 (1977), esp. at 230. Justice O'Connell was considered by Catholics to be antiCatholic (per communication from Jesuit Historian Father Wilfrid Schoenberg). Linde wrote: "We agreed that the Oregon Bill of Rights, Article I of the Constitution, should provide needed protections for individual rights which had not then been extended by the U.S. Supreme Court, and these were included in the Commission's proposed constitution. Although the revised Constitution was not enacted, judical decision subsequently caught up with a number of the 'proposed reforms'n (emphasis added). In a forum on the First Amendment at Reed College on November 16, 1984, Linde said that he had sought to make changes in the Oregon Constitution when he was part of the Revision Commission, which proposals were rejected, but that when he became judge, he "found" the changes to have been there all along.

76. December 1984 ACLU Annual MeNaughten Award Dinner in Portland, Oregon.

77. Saalfeld, 9 .

78. Lowe v City of Eugene. 254 Or. 518, 528 (1969). "If a thing has been practiced for two hundred years by common consent, it will need a strong case for the Fourteenth Amendment to affect it." Oliver W. Holmes Jr., quoted at 88, Manning. Cf. Rhenquist in his Wallace dissent.

79. Cf. 1973 Oregon Blue Book and 1972 Voters Pamphlet (Secretary of State, Salem, Oregon. 1972 and 1973).

80. ACLU Files, Portland, Oregon. Court Records of Cogan v Atiyeh. Annual Reports of the Oregon State Scholarship Commission. Phone Interviews and Reports of the Oregon State Scholarship Commission. Phone Interviews and Correspondence with the Scholarship Commission's staff, especially Thomas Turner, who was involved in the case and familiar with its over $2 \mathrm{l} / 2$ feet of files. Interviews with staff of Judson Baptist College. Cf. Larry Large, Impact of State Assistance on Oregon's Private Colleges (Ph. D. dissertation. University of Oregon. 1974).

81. But only because they believed that federal law would still prohibit the practice. The Oregonian. June 1985. Actually, the case was not compromised. The Appeals Court sustained the prohibition, but struck the penalty. Its decision was appealed to the Oregon Supreme Court.

82. Lawrence M. Friedman. A History of American Law (Simon and Schuster. New York. 1973), e.g. at 311: "Judicial review of State statutes was a rare, extraordinary event in $1850 . .$. "

83. From Thomas Miann's The inagic Mountain, which portrays its 
protagonist living apart in a Swiss sanatorium until, with the onset of World War I, he comes down to join the rest of the world.

84. "....while protesting its unwillingness to infringe upon the "judicial functions properly inherent in ecclesiastical authorities," the Nebraska Supreme Court had done just that," Zabel, above, 5l. It is a commonly recognized technique of courts, especially when making new law, to announce one principle while they act according to its opposite. In Watson v Jones, 80 U.S. 679 (1871), in a diversity case, the Supreme Court held that federal courts lack the power to resolve church property disputes by a judicial determination of ecclesiastical dogma. This principle became one of federal constitutional dimension in Kedroff $v$ St. Nicholas Cathedral, 344 U.S. 94 (1952).

85. Cf. Frederick A. Norwood, The Story of American Methodism (Abingdon Press. Nashville, Tn. 1974. 1981), at 324ff. The brethren later merged into the United Methodists.

86. Cf. Howe, Chapter III, referring to the "extravagance of litigation" which followed these schisms and secessions.

87. The underlying substantive issues involved whether permanent or accommodationist-to-the-times interpretations of Scripture should be made.

88. At 393, Headnotes.

89. At 396 .

90. Thus the result was consistent with the principles developed, often by trial and error, in most American jurisdictions. Howe, Chapter II: "The judges everywhere recognized that if every commitment of property to a religious enterprise created an enforceable trust the American courts of equity would find themselves entangled with refined intricacies of theology and religious dogma," 48. In deciding the question of "which Majority," American courts came to choose the method of refusal to enquire into theological disputes - what became known as the "American Rulen. The Rule, however, appears capable of manipulation to reach results which only make sense if the prohibited factors had been considered.

91. In Watson, the U.S. Supreme Court, on common law principles, had awarded Presbyterian Church property to the faction loyal to the Union. But in the 1952 Kedroff case, it asserted that, regardless of politics (The Russian Orthodox Church was alleged to be under control of the Soviet government) the supremacy of the church's central organs of government must be respected by the State. Howe interprets these two cases as bending to the political winds of their times, in the one case national, in the latter case international.

In 1855, a dispute had arisen among Baptists over control of the Albany Church. Two trials ensued, one over the property itself and a second over possession of the record book. The Old Baptists prevailed, but the case was decided based upon who had been in possession. Miller, 247.

92. Scheck, 43.

93. See the Chapter on Tax Exemption (chap. 9) in Zabel for a discussion of the alternative methods states have chosen in regulating the 
amounts of property churches might retain exempt from taxation. The "use" method is one which, in attempts to apply it, has resulted in continuous litigation. (1819).

94. Chief Justice John Marshall, Mccullough $\nabla$ Maryland. 17 U.S. 316

\section{Sweet, 189.}

96. It is also worthy of note that Oregon refrained from joining the many states which altered their Constitutions in the latter half of the $1800 \mathrm{~s}$ to prohibit the use of public funds for the support of denominational schools. Howe, 131. In 1962, although ACLU deplored Oregon's lack of such a provision, the Constitutional Revision Commission declined to introduce it.

97. Cf.Lord's Oregon Laws, 114."excepting such only for municipal, educational, literary, scientific, religious or charitable purposes, as may be specially exempted by law." The 1917 Constitutional change by Initiative was not intended to affect religious and charitable exemptions, but only to ensure a fair and equitable tax system and to allow exemption by categories. The existence and extent of religious exemption was left, after as before, with the legislature, as a matter of legal privilege, not right.

98. Bone, 190.

99. It is worth remembering that every case on religion involves a question of policy, which might have been decided otherwise.E.g. an extreme interpretation of the Jeffersonian position led the Virginia Court of Appeals to adopt the "startling doctrine that no trust for religious purposes is enforceable in the courts of Virginia".

The case is described by Howe at 2. In the opposite direction, the Nebraska Supreme Court held that the property of religious societies may not be diverted, and applied that long-standing rule to prevent a mortgagor from seizing church property. Zabel 48-49.

100. This case came only six years after the U.S. Supreme Court announced in Shelly $v$ Kraemer that racially restrictive covenants in private conveyances would not be honored by the courts.

101. Other States continue to recognize title in trustees. Virginia still prohibits incorporation of any church and thus must recognize trustees.

102. Until 1969 the State Tax commission. ORS 305.025. The commission had been created in 1909.

103. This development confirms the predictions of Howe on the effect of "equality" of treatment by the government in reducing the de facto institutionalization of Protestant Christianity over time. Chapters IV and VI, esp. at 160. Leo Pfeffer, e.g. has argued for the constitutional security of disbelief in Church, State and Freedom, 498-99.

104. Linde had been law clerk to U.S. Supreme Court Justice William O. Douglas, who advocated taxation of churches and indeed wrote in Walz v Tax Commission that excusing churches from taxation was on impermissible 
establishment of religion.

Interestingly (for this thesis) the Walz case upheld church tax exemption, in disregard of the strict logic of current constitutional interpretation of religion, by finding a clear historical warrant for it. The Walz analysis, similar to the prevailing analysis in the first Eugene Cross Case, is what this thesis proposes as the proper method of analysis in its respect for what the practices of the people were.

105. Lecture to 1985 Oregon State Bar program on Oregon Constitutional Law.

106. Morgan, 131. "These radical secularists tend to regard private charitable activity as illusory and psychologically corrupting.....Religious schools....are to be tolerated as an option of the ignorant, not encouraged to compete with the single legitimate dispenser of social services--the secular state". 20th Century intellectuals, taught by Freud and Marx that religion is a fraud and an illusion, and conditioned by the battle over Darwinism to regard it as a virulent anti-intellectual disease, have looked unkindly on any ef fort to provide state funds to religions. To them, the public schools are the same kind of tool to eliminate religion as Protestants have thought or hoped the schools could be to eliminate Catholicism.

107. The author's view on the extent of credit to be given the Klan for passage of the School Bill differs from that of some Oregon historians, such as Father Saalfeld, Father Schoenberg or David Horowitz, but develops the insights of other Oregon historians such as Recken and Zellman. For a fuller account of the facts and controversy, see the author's 1984, The Oregon School Bill of 1922: A Reevaluation. After careful review, and long discussions with Saalfeld, Schoenberg \& Horowitz, the author remains persuaded of the correctness of his 1984 views.

108. E. Kimbark MacColl, The Growth of a City. Power and Politics in Portland, Oregon 1915-1950. (Portland, Oregon. The Georgian Press. 1981), 172 quoting Outlook correspondent Waldo Roberts on the Klan and the School Bill.

109. "Speech on Conciliation with the Colonies". March 22, 1775.

110. Letter of Oregon Inspector General David O. Johnson, 1984, and private conversations and correspondence with the author.

11l. Proceedings of the Grand Lodge, Ancient and Free Accepted Masons of Oregon. (Portland, Oregon. 1921-22) Saalfeld, 118.

112. National Masonic representative William MacDougall, quoted at

113. Saalfeld, 18, quoting Oregon Masonic leader Robert E. Smith.

114. John Dewey, My Pedagogic Creed, quoted at Richard Hofstadtler, Anti-Intellectualism in American Life (Random House. New York. 1962), 367.

115. The Oregonian, October 31, 1922.

116. George S. Turnbull. George Putnam, An Oregon Crusader. 
(Portland, Oregon. Binford and Mort. 1955), 78-79.

117. Suggested by Hall S. Lusk, lawyer for the Sisters and later Oregon Supreme Court Justice, who reviewed Ralph E. Bunch's Pierce v Society of Sisters: The Oregon School Case (M.A. Thesis. University of Oregon. 1961).

118. David Tyack, "The Perils of Pluralism. The Background of the Pierce Case." American Historical Review LXII (Oct. 1968).

119. Recken, 56.

120. Kenneth Jackson. The Ku Klux Klan in the City 1915-1930 (Oxford University Press. New York. 1967), Chepter 14, "Portland: Headquarters of the Realm."

121. Jackson, xii.

122. The author was raised as a Catholic, spent four years in a Catholic seminary and has taught in Catholic schools. This paper has been reviewed at various stages by Catholic historians Father Schoenberg, Father Pat Lee, and Father Saalfeld. Sources include especially the histories by Carey, Knuth, O'Hara, Saalfeld, Wooten, Clark, Schand, and Schoenberg.

123. A 1919 law already required all schools to be conducted in English only. Olson's Oregon Laws. 2222-2223.

124. Interview with Father Patrick Dowd, Pastor of St. Patrick's Catholic Church, Canby, Oregon.

125. Author's personal observations in 1984-85.

126. The Columbian, June 21, 1985.

127. The Oregonian, June 15, 1985. Article about the authors of Lesbian Nuns: Breaking Silence.

128. The main source on Christian Scientists in Oregon is Roy Molen Swenson, The Seekers of the Light--Christian Science in Oregon 1880-1915. (M.A. Thesis. University of Oregon. 1969).

129. Swenson, $88 \mathrm{ff}$. The laws were changed to protect religious healing practices. "Nothing in the administration of the health laws may interfere with the practices of any person or institution whose religion treats or administers to the sick or suffering by purely spiritual means." Oregon law, quoted at Catholic Encyclopedia, Vol. 10, 737.

130. Swenson, 115 .

131. One watches a similar strategy at work with the Unification Church and its ownership of the Washington Times.

132. On the Peace Churches, see especially Beebe, Fogelquist, Scheck, Silverman, Untiedt. For background see John A. Hostetler's Amish Society, 3rd edition (Johns Hopkins University Press. 1980). For the most part, 
problems over pacifism occurred during the First World War. As Gaustad notes in Dissent in American Religion (University of Chicago Press. 1973), the Conscription Act of 1940 was written in consultation with the Historic Peace Churches, and provided for alternative service, 135-136. The author has represented and advised Friends on Selective Service matters for many years, and during the period 1963-75, and 1982-83, was actively involved with a Friends Meeting and with the American Friends Service Committee.

133. Beebe, 77 .

134. Beebe, 78 .

135. Statistics for the years 1945, 1954, 1960 and 1967 are found in Beebe, 118.

136. Gaustad, 135-136.

137. Scheck, 107.

138. Scheck, 115, Note 1. This kind of law was declared unconstitutional by the U.S. Supreme Court in the 1923 Meyer $v$ Nebraska decision.

139. The author has interviewed many witnesses over the years on their proselytizing and pacifistic beliefs, and has visited Witnesses in Allenwood Federal Prison, where they were serving time for refusal to cooperate with the Selective Service System.

\section{Cf. the 1958 Mullen case.}

141. See the account in In the Service of Their Country: War Resisters in Prison, Willard Gaylin, M.D. (Viking. New York. 1970).

142. See especially Toll, Urofsky, Oral Interview of Judge Gus Solomon (in possession of Jewish Historical Society, Portland, Oregon), and author's paper on ACLU of Oregon, whose Jewish members have been a strong voice in ACLU and Oregon's development on religious-state matters.

143. The Civil Rights act originally did not contain language protective of religion, Morgan, 45, but was amended later to do so.

144. Based upon author's interviews, experience, and representation of ISKCs, interviews with Adrian Greek of the Positive Action Center, and the cases described.

145. See especially Richard E. Morris, John Sabey, Carol Silverman, Jules Untiedt, Marion County Russian Resource Committee, Interview with Margaret McKibbin, and sources cited therein. Morris, Bi-lingual Schooling, 2: "...it is characteristic that most Old Believer children drop out of school just prior to the seventh grade". Marion County Manual, 12: "It is obvious that Juvenile authorities have no intention of becoming involved in training cases on a regular basis," that conclusion based upon a letter at 39-40 summarizing the local prosecutor's and court's non-interference position. Cf. Morris, Three Russian Groups, 161. At 16, it is noted that the parents, who believe that 
the pledge of allegiance is a prayer, do not allow their children to take part.

146. The Oregonian, 1978. Interview with Adrian Greek. Interview with Margaret McKibbin, who was interpreter in the case. In Marion County, the authorities, using cultural sensitivity and relying upon the U.S. Supreme Court case of Yoder $v$ Wisconsin, which gave special protection to Amish who withdrew their children from high school, have not enforced the state laws strictly against non-attendance. The one case which arose did so because one Old Russian Believer family lived in Clackamas County, where they were an oddity. The family finally fled to Alaska to avoid what they saw as religious persecution . Curiously, in 1984-1985 the Clackamas County authorities, for budgetary reasons, are not enforcing the school attendance laws against anyone.

147. The Old Russian Believers, apart from the area of school attendance, come into regular contact with the law because of customs of wife and child beating. The Marion County Courts have accommodated here by finding other Old Russian relatives to take in abused children, but have been largely unsuccessful in dealing with spousal physical discipline. The case received prominent local and national press coverage, including The New York Times.

148. See Underwood, Greek, and relevant cases.

149. See the Shays' Calendar and book, Braun's book, and The Oregonian's highly colored but summary 20-part series published in July 1985. The author, as part of ACLU Lawyers Committee, has listened to Rajneeshee lawyers and officials, and participated in a special debate program on Rajneeshpuram before the Portland City Club in 1984.

150. "Fundamentalist Schools vs the Regulators," The Wall Street Journal, April 14, 1983. ACLU files.

151. ACLU files.

152. Morgan, 133-134.

153. Carey, History, 702.

154. Carey, History, $699 \mathrm{ff}$.

155. It was "the Catholic grievance that Protestant tradition and doctrine permeated the public system," met by "the reluctant admission of the old-line possessors of power that this was so." Howe, 130.

156. Quick, 57-58. Cf. the discussion of Atkinson in Tyack's articles.

157. "Grant's annual message to Congress in December (1875) stressed the importance of a constitutional amendment forbidding the appropriation of public funds for denominational schools." Higham, 19. Cf. Meyer and O'Brien on the Blaine Amendment.

158. Ahlstrom, Vol. 2, 339-340. 
159. William O'Brien writes: "The traditional American school was the religious school founded and directed as a joint enterprise of church and community ... "Although the "American schools gradually ceased to be sectarian, the majority of them continued to be religious institutions for a considerable period of time. The religion taught in these schools consisted of the general principles of Protestantism which radiated from a study of the Bible." at 144.

Cf. Farnham, Chapter VI,noting the widespread use of the Bible as a text (218) and that "Bible and prayer remained unchallenged in the daily school routine." (231).

160. Schand.

161. at 132 .

162. Wardin, 385 .

163. By contrast, the Nebraska Attorney General decided its law did not apply to nuns obtaining required teaching certificates.

164. ACLU Annual Report, 1926.

165. Files of the Oregon Constitutional Revision Commission. State Archives. Salem, Oregon. At the 1857 Constitutional Convention, there was a minority report on education by P.B. Marple, which was tabled. Its section 3 read:

"no part of the common school fund shall ever be granted for the use or benefit of any religious sect and no distinction shall be made on the basis of religious opinion"

166. Interview with Judge Jonathan Neuman, 1985.

167. Cf. Handy, 319-320. McAvoy, 37 .

168. Court files, correspondence of the parties (in ACLU files) and interviews with Father Saalfield.

169. "Separation of Church, State Demands Persistence, Vigilance,"The Oregonian, October $21,1983, \mathrm{C} 13$.

170. Cf. Alan L. Gallagher, The ACLU in Oregon from 1920-1955. (unpublished. 1981). Robert A. Burton, Democrats of Oregon (University of Oregon. 1970).

171. During the 20th Century, judges and legal scholars developed the concept that some or all of the provisions of the federal Bill of Rights were, by incorporation into the 14th Amendment, made binding upon the states. There is a huge literature on the historical and juridical validity of the various incorporation theories. The author believes they are nearly all historically unwarranted and recommends the analysis of Raoul Berger, Government by Judiciary, The Transformation of the Fourteenth Amendment (Harvard University Press. Cambridge, Mass. 1922). 
172. Initial funds to start $\mathrm{AU}$ in 1948 were provided by the Masons, Scottish Rite. Morgan, 60.

173. Morgan distinguishes between separationist and accommodationist groups, and observes that as government comes to do more and more, the occasions for church-state conflict arise more frequently. Cf. Richard E Morgan, The Politics of Religious Conflict: Church and State in America (University Press of America, Wash. D.C. 1980).

174. Howe, 109.

175. See account in Wardin, Baptists in Oregon (Judson Baptist College. 1969), 37ff, where the early churches were described as "moral courts of the frontier."

176. Lord's Oregon Laws contains the crime of abortion, and a Chapter VII: "Of Crimes Against Morality and Decency," which includes adultery, polygamy, sodomy, prostitution and gambling, as well as a catch-all in section 2087 for any of fensive behavior which the legislature may have forgotten. Chapter VIII prohibits loteries and a wide range of Sunday activities, including barbering, but allows that "all circumstances of necessity and merey may be pleaded in defense." (2125). Today, this list reads like a list of activities progressively made legal. Some of the Sunday Closing Laws were repealed in 1916 (Wardin, 272), but a good part remained.

177. " ... the triumph of prohibition in the 18th Amendment was the last great victory of agrarian America against the power of the cities. In the campaign, the Methodists played a crucial role ... " Norwood, 397. Cf. Clark in Deady's Journals, Vol. I, 179, and his "War on the Webfoot Saloon," Oregon Historical Quarterly LVII (March 1957) 48-62.

178. The Oregon Constitution continued in force all territorial laws not specifically repealed. Art. XVII, Section 7 .

179. This observation was made at a time when the State was conceived to have all powers not specifically denied to it, and the federal government was conceived to have only those powers specifically granted to it.

\section{Wardin, 272.}

181. Duniway later judged that the linkage was politically detrimental and separated herself and the suffrage movement from the religiousdominated prohibition movement. Dodds, 175-178

182. This became especially true during the campaigns of Al Smith, who was opposed by Methodists because he was a Roman Catholic and a Wet. "Inextricably enmeshed in the prohibition struggle were issues of rural-urban strain, ethnic tension, Protestant-Catholic controversy, Church-State relationship, adjustment of means to ends ... "Norwood, 397. The Social Gospel and Prohibition became the guiding lights as churchmen sought to reform mankind through the instrument of the State. (Quoting from Robert Miller, History of American Methodism, III, 330). 
183. Clark, 137, "The Bigot Disclosed".

184. Clark, 143.

185. Blanshard wrote anti-Catholic articles for The Nation and wrote such books as American Freedom and Catholic Power, which presented Roman Catholicism as an active enemy of American democratic institutions.

186. "The American experiment, the American folly, was to place both orthodoxy and dissent upon the same shifting platforms of public favor and public support." Gaustad, 3.

187. Although the 1985 law allowing school funds to be withheld from any district supporting religious activity may prove to be a major end run around the standing problem. It could seriously reduce local options and allow such groups as ACLU to sue without injured local plaintiffs. 


\section{XIII - SOURCES}

\section{(a) BIBLIOGRAPHIC ESSAY}

The standard histories of Oregon contain little information on religion, apart from accounts of the founding of the State and of the Oregon School Bill period. Even those are sparse and contain incorrect information. Most are not included in the bibliography because they lacked information. For analysis, see Gallagher's The Oregon School Bill of 1922.

In preparation of this thesis, an outline calendar of religious events and themes in Oregon history was prepared and submitted to historians Thomas D. Morris, Gordon B. Dodds, Fr. Lawrence Saalfeld, Fr. Wilfred Schoenburg S.J., James Schand, Fr. Pat Lee S.J., and students of religion and law Charles Hinkle, Claudia Burton, Stevie Remington, and Bill Long. Their comments were used to ensure that significant events had not been missed. Many of them also read the thesis in draft.

Theses at state schools (University of Oregon, University of Portland, Reed, Oregon State University, Portland State University) and at Catholic University were reviewed. A thorough search was made of Oregon federal and state cases, Oregon Attorney General Opinions, and indices of the Pacific Northwest Quarterly, the Oregon Historical Quarterly, the Oregonian, and the Catholic Sentinel. Biographies of leading legal and religious actors in Oregon, such as Judge Mathew Deady, Governor and Congressman Walter Pierce and his wife, Father Edwin O'Hara, Rabbi Stephen Wise, Rev.Thomas Lamb Eliot, Senator and Judge George Williams, and Dudley Wooten were reviewed to provide background and insight. Histories of major religious groups in Oregon were reviewed.

The period of the Klan and the School Bill has generated a substantial 
literature, mostly in theses and journals. The general histories treat the period briefly and usually with errors. A very few items of the literature contain balanced and reliable analysis. The best accounts, though they differ among themselves, are those of Tyack, Saalfeld, Malcolm Clark, and Gallagher. The large volume of cases and opinions is best reduced to thematic analysis. A detailed accounting would be of exteme length, whereas the major themes are clear. The annotations of the cases and opinions will give the reader quick entry into each controversy. These reported controversies may or may not be representative of the entire world of legal controversy. It is unlikely that they are, as few cases usually make it to the appellate or reported level. The arrests and trials of Witnesses or "Hare Krishnas", e.g., are low-level incidents, which rarely achieve public notice at all. Like acorns, most cases never grow into the oaks of appellate cases. Most never even reach the newspapers. To achieve some thematic adequacy, a review of general church histories and controversies throughout the country was made, as well as a review of files and records of the American Civil Liberties Union, to identify controversies. One can be aware that some controversies also occured here, e.g. the imprisonment of members of Peace Churches, although data may be hard to come by. 
(b) BOOKS, ARTICLES, ARCHIVES

Abraham, Henry J. Freedom and the Court: Civil Rights and Civil Liberties in the United States. 4th ed. Oxford University Press. New York. 1982 .

Ahlstrom, Sydney E. A Religious History of the American People. Image Books. Doubleday and Company, Inc. Garden City, New York. 1975. Vol. 2.

American Civil Liberties Union. Portland, Oregon. Files.

Antieu, Charles James, Cande, Phillip Mark, and Burke, Thomas Arnold. Religion Under the State Constitutions. Central Book Co. New York. 1965

Ballot Measure. See 1973-1974 Oregon Blue Book. 1972 Voters Pamphlet (Secretary of State). Proposed amendment would have made Article 1, Section 5 like the US First Amendment. Meant to overturn Dickman and allow same as U.S. Supreme Court.

Baitzell, E. Digby. The Protestant Establishment. Aristocracy and Caste in America. Vintage Books. Random House. New York. 1966.

Beebe, Ralph K. History of Oregon Friends. M.A. Thesis. University of Oregon. 1969 .

Berns, Walter. The 1st Amendment and the Future of American Democracy. New York. Basic Books. 1976.

Billington, Ray Allen. The Protestant Crusade 1800-1860: A Study of the Origins of American Nativism. Macmillan. New York. 1938. (1952).

Blau, Joseph L. Cornerstones of Religious Freedom in America. Revised ed. 1964.

Bone, Arthur H. Oregon Cattleman/Governor/Congressman. Memoirs and Times of Walter M. Pierce. Oregon Historical Society. Portland, Oregon. 1981.

Braun, Kirk. Rajneeshpuram: The Unwelcome Society. Cultures Collide in a Quest for Utopia. Scout Creek Press. West Linn, Oregon. 1984. Introduction by Professors Carey and Ted Shay.

Brisley, Melissa Ann. Cornelia Marvin Pierce. A Political Biography. Thesis. Reed College. Portland, Oregon. 1966.

Burton, Claudia and Collins, Ronald. Text On Oregon Constitutional Law. Unpublished. Used at Willamette University Law School. Salem, Oregon. 1983-1985.

Callister, Scotte, Long, James, and Zactz, Leslie. "For Love or Money". The Oregonian, 20 part series on Rajneeshees. June 30, - July 19, 1985. 
Cannon, Dale W. and Runkel, Ross R. Teaching About Religion. Oregon College of Education. Monmouth, Oregon 1979.

Carey, Charles H. LLD. General History of Oregon. Binford and Mort. Portland, Oregon. 3rd ed. 1971

The Oregon Constitution and Proceedings and Debates of the Constitutional Convention of 1857. State Printing Department. Salem, Oregon. 1926.

Catholic Encyclopedia. "The Blaine Amendment" Vol. 2, pp 599-600. "Oregon" Vol. 10, p 737. McGraw-Hill Book Co. New York. 1967.

Clark, Malcolm, Jr. "The Bigot Disclosed: Ninety Years of Nativism." Oregon History Quarterly. LXII. June 1974. 109-182.

Pharisee Among Philistines. Diary of Judge Matthe $\bar{P}_{0}$ Deady. 1871-1892. Oregon Historical Society. 1975. 2 volumes.

Cobb, Sanford H. The Rise of Religious Liberty In America. Macmillan and Co. New York. 1902. Reprinted in 1970 with an introduction by Paul L. Murphy.

Cooley, Thomas. Constitutional Limitations. Boston. Lit tle, Brown. 1868.

Cord, Robert L. Separation of Church and State - Historical Fact and Current Fiction. Lambeth Press. New York. 1982.

Donohue, William A. The Politics of the American Civil Liberties Union. Transaction Books. New Brunswick, New Jersey. 1985.

Drinan, Robert. Religion, The Courts and Public Policy. McGraw Hill. New York. 1963.

Farnham, Wallace D. Religious Tolerance In Life and Thought: Jackson County, Oregon. 1860-1890. PhD. Dissertation, University of Oregon. 1955.

Fogulquist, Albin M. Lutheran Province in the Pacific Northwest Prior to WWI. University of Oregon. PhD Dissertation.

Friedman, Lawrence M. A History of American Law. Simon and Schuster. New York. 1973.

Gallagher, Alan L. The Oregon School Bill of 1922: A Reevaluation. M.A. Thesis. Corpus Christi State University. 1984

The Oregon School Bill of 1922. Unpublished essay written for the Oregon Committee on the Humanities. 1985.

Breaking the Silence: Law and Religion in Oregon History. Unpublished essay written for the Oregon Committee on the 
Humanities. 1985.

The American Civil Liberties Union In Oregon: 1920-1955. Unpublished essay. 1982.

Gaustad, Edwin Scott. Dissent In American Religion. University of Chicago Press. Chicago. 1973.

Goldberg, George. Reconsecrating America. W. B. Eardman's Publishing Co. Grand Rapids, Michigan. 1984.

Greek, Adrian and Anne. Mind Abuse by Cults and Others. Postive Action Center. Portland, Or. 1985.

Gunns, Albert Francis. Civil Liberties and Crisis - The Status of Civil Liberties in the Pacific Northwest 1917-1940. PhD. Dissertation, University of Washington. Seattle. 1971.

Handy, Robert T. A History of the Churches In the United States and Canada. Oxford University Press. New York. 1976 (1979).

Higham, John. Strangers In the Land: Patterns of American Nativism 1860-1925. Atheneum. New York. 1963.

Hinkle, Charles R. "Freedom of Religion" in Oregon Constitutional Law. Oregon State Bar. Portland, Oregon. 1985.

Hixon, Margaret. Old Believers. Oregon Committee on the Humanities/B. Dalton. Por tland, Or. 1981.

Hultkrantz, Ake. The Study of American Indian Religions. Edited by Christopher Vecsay. Crossroad Publishing Co. New York. 1983.

Horwitz, Morton J. The Transformation of American Law. 1780-1860. Harvard University Press. Cambridge, Mass. 1977 (1981).

Howe, Mark DeWolf. Cases on Church and State in the United States. Harvard University Press. 1952.

Howe, Mark DeWolf.The Garden and the Wilderness: Religion and Government in American Constitutional History. University of Chicago Press. 1965.

Howell, Erle. Methodism in the Northwest. Parthenon Press. Nashville, Tennessee. 1966.

Johnson, Alvin W. and Yost, Frank H. Separation of Church and State in the United States. Minneapolis. 1948. This is a revised and enlarged edition of Johnson's 1934 The Legal Status of Church-State Relationships in the United States.

Kent, James. Commentaries On American Law. 9th ed. Little, Brown. Boston. 1858. 
Association. University of Washington Press. Seat tle. 1964.

Knuth, Priscilla F. Nativism In Oregon. Thesis. Reed College. Portland, Oregon. 1947.

Kurland, Phillip B. (Ed). "Church and State. The Supreme Court and the 1st Amendment". Article for the Supreme Court Review. University of Chicago. 1975.

Larson, Bob. Larson's Book of Cults. Tyndale House Publishers. Wheaton, Ill. 1984.

Lewis, Ira. "Education in Oregon Constitutional Convention of 1857". Oregon Historical Quarterly. 23,p. 220-229.

McAvoy, Thomas T. The Americanist Heresy in Roman Catholicism. 1895-1900. University of Notre Dame Press. North Bend. Indiana. 1963.

McClellan, James. Joseph Story and the American Constitution. University of Oklahoma Press. Norman, Ok. 1974.

McGuffey's Fifth Eclectic Reader. 1879 Edition. New American Library. New York. 1962.

McLagan, Elizabeth. A Peculiar Paradise: A History of Blacks in Oregon 1788-1940. Georgian Press. Portland, Oregon. 1980.

McNall, Scott G. The Freedom Center. A Case Study of A Politico-Religious Sect. (Walter Huss and Co). PhD. Dissertation. University of Oregon. 1965.

Malbin, Michael J. The Supreme Court and the Definition of Religion. PhD. Dissertation. Cornell University. (1973).

Manning, Leonard F. The Law of Church-State Relations. West Publishing Co. St. Paul, Minn. 1981.

Marion County (Oregon) Russian Resource Committee. Manual for Educators of Russian Old Believers in Oregon. Marion County I.E.D. Salem, Or. October, 1976.

Marty, Martin. Pilgrims in Their Own Land. 500 Years of Religion in America. Penguin Books. New York. 1984.

Maynard, Theodore. The Story of American Catholicism. Image. Doubleday and Company, Inc. Garden City, New York. 1960.

Mead, Frank S. Handbook Of Denominations in the United States, 7 th Ed. Abingdon Press. Nashville. 1983.

Mecklin, John Moffett. The Story of American Dissent 1871-1965. Kennekut Press. 1970.

Meyer, Alfred. "The Blaine Amendment and the Bill of Rights". 64 Harvard 
Law Review 939. (1951).

Miller, Charles A. The Supreme Court and the Uses of History. Simon and Schuster. New York. 1969 (1972).

Miller, Clifford R. Baptist Beginnings in Oregon 1840-1870. PhD. Dissertation. University of Oregon. 1955.

Miller, Perry. Roger Williams, His Contribution to American Tradition. Atheneum. New York. 1962 .

Moehlman, Conrad H. Comp. The American Constitutions and Religion. A Sourcebook on Church and State in the United States. 1938.

Morgan, Richard E. The Politics of Religious Conflict: Church and State in America. University Press of America. New York. 1968.

Morris, Richard A. Bi-lingual Schooling, Bi-cultural Exposure and Social Cohesiveness: A Comparison of Two Russian Communities. Paper read to Alaska Anthropological Assoc. April, 1982.

Morris, Richard A. Three Russian Groups in Oregon: Comparison of Boundaries in a Pluralistic Environment. Ph.D. Dissertation. University of Oregon. 1981.

Murphy, Paul L. World War I and the Origin of Civil Liberties in the United States. W.W. Norton \& Co. New York. 1979.

Myers, Gustavus. History of Bigotry in the United States. Random House. New York. 1941.

Northwest Ordinance of 1787.

Norwood, Frederick A. The Story of American Methodism. Abingdon Press. Nashville, Tennessee. 1981 (1974).

O'Brien, William Francis "The Blaine Amendment 1875-76". 41 Detroit Law Review 137-205 University. 1962.

O'Hara, Edwin Vincent. Catholic History of Oregon. Catholic Book Co. Portland, Oregon. 1925.

Oregon Law Index (To 1866). Steven-Ness Co. Portland, Oregon. 1937.

Oregon State Bar. Oregon Constitutional Law. Chapter 2 "Freedom of Religion". C. Hinkle. Portland, Oregon. 1985.

Oregon State Constitution. (See Carey and the Oregon Blue Book for Standard editions).

Oregon Constitution Revision Commission Report. Salem, Oregon. 1962. The Minutes and Records of the Commission are in two boxes at the Oregon State Archives in Salem. 
Oregon Board of Education. Model Policy For Oregon Schools With Respect To Religion. Salem, Oregon. 1969.

Overmeyer, P.M. The Oregon Justinian. (Mathew Deady) PhD. Dissertation. University of Minnesote. 1940.

Paulsen. State Constitution, State Courts and 1st Amendment Freedoms. 4 Law Review. p.628 (1951).

Pfeffer, Leo. God, Caesar and the Constitution. Beacon Press. Boston. 1975.

Practicing Law Institute (PLI). Recent Developments in State Constitutional Law. New York. 1985.

Quick, Alan F. History and Development of Common School Fund in Oregon 1849-1872. PhD. Dissertation. University of Oregon. 1963.

Recken, Stephen Louis. A Reinterpretation of the Oregon School Bill of 1922: The Concept of the Common School in Progressive America. MA Thesis. Portland State University. Portland, Oregon. 1973.

Rhenquist, Justice William. Dissenting opinion in Wallace v Jaffree, $105 \mathrm{~S}$. Ct. 2479 (1985).

Reynolds, Charles. "Portland Public Schools 1845-1871". Oregon Historical Quarterly. XXXIII (December 1932) pp. 334-347.

Richey, Russell E. and Jones, Donald G., editors. American Civil Religion. Harper and Row. New York. 1974.

Rosten, Leo. Religions of America. Simon and Schuster. NY 1978.

Saalfeld, Father Lawrence. Forces Of Prejudice In Oregon 1920-1925. (MA Thesis. Catholic University of Americe. Washington, D.C. 1950.) University of Portland. Portland, Oregon 1985.

Sabey, John. Staroveri and School: A Case Study. of the Education of Russian Immigrant Children in a Rural Oregon Community. Ph.D. Dissertation. University of Oregon. 1969.

Schand, James. Garb Bill. Unpublished. 1984.

Scheck, John Frederick. The Beginnings of the German Lutheran Church In Oregon. MA Thesis. University of Oregon. 1961.

Scheck, John Frederick. Transplanting A Tradition: Eliot and the Unitarian Conscience 1865-1905. PhD. Dissertation. University of Oregon. 1969.

Schoenburg, Wilfred, S.J. Paths to the Northwest: A Jesuit History of the Oregon Province. Loyola University Press. Chicago. 1982.

Schwartz, Michael. The Persistent Prejudice: Anti-Catholicism in America. 1985. 
Shay, Ted and Shay, Carey. Calendar on Rajneeshpuram. Unpublished. Salem, Oregon. 1984.

Rajineeshpuram and the Abuse of Power. Scout Creek Press. West Linn, Or egon. 1985.

Shaw, J.G. Bdwin O'Hara: American Prelate. New York. 1957.

Silverman, Carol. Russian Old Believers. Oregon Committee on the Humanities, Portland, Oregon. 1984. Film and lecture on folklore and background. Interview 1985.

Sorauf, Frank J. The Wall of Separation: The Constitutional Politics of Church and State Princeton U. Press NJ. 1976

Stokes, Anson Phelps and Pfeffer, Leo. Church and State in the United States. Harper and Row. New York. 1964.

Story, Joseph. Commentaries on the Constitution. Boston. Little Brown. 1873.

Sweet, William Warren. The Story of Religion in America. Harper \& Row. New York (1930) 1950.

Swensen, Roy Molen. The Seekers of the Light - Christian Science in Oregon. 1880-1915. M.A. Thesis. University of Oregon. 1969.

Tarr, George Allen. Judicial Impact and State Supreme Courts. Lexington Books. Lowell, Ma. 1977.

Tiernay, Brian. The Crisis of Church and State 1050-1300. Prentice-Hall Inc. Englewood Cliffs, New Jersey. 1964.

Toll, William. The Making of an Ethnic Middle Class: Portland Jewry Over Four Generations. State University of New York Press. Albany, New York. 1982.

Tyack, David. "The Kingdom of God and the Common School: Protestant Missionaries and the Educational Awakening in the West". Harvard Educational Review. Vol 36 (Fall 1966) 447-469.

"Bureaucracy and the Common School: The Experience of Portland, Oregon 1851-1913". American Quarterly. (Summer 1967) XIX, 475-498.

Underwood, Betty and Barbara. Hostage to Heaven. Clarkson N. Potter Inc. New York, NY. 1979.

Untiedt, Jules A. Impingement on Old Believers in Oregon by Agents of Social Change. PhD Dissertation. United States International University. San Diego. 1977.

Urofsky, Melvin I. A Voice That Spoke For Justice: The Life and Times of Stephen S. Wise. S.U.N.Y. Press. Albany, New York. 1982. 
Van Allen, Roger. The Commonweal and American Catholicism. The Magazine, The Movement, The Meaning. Fortress Press. Philadelphia, Pa. 1974.

Wilner, Don. Text on Oregon Constitutional Law. Unpublished. Used at Lewis and Clark Law School. Portland, Oregon. 1983.

Warden, Albert W. Jr. Baptists In Oregon. Judson Baptist College. 1969.

Woodward, Robert C. Education in Oregon in the Progressive Bra: Liberal and Practical. PhD. Dissertation. University of Oregon. 1963.

Wooten, Dudley. Remember Oregon. American Publishing Company. Denver, Co. 1922.

Zabel, Orville H.God and Caesar in Nebraska - Church and State 1854-1954. University of Nebraska. Studies \#14. Lincoln, Nebraska (1955).

Zollman, Carl. American Church Law. West Publishing Co.. 1933.

Zucker, Jeff, Hogfass Bob and Hummel Kay. Oregon Indians: Culture, History and Current Affairs, Atlas and Introduction. Oregon Historical Society. Portland, Oregon. 1984. 


\section{(c) CASES}

A complete list of Oregon's appellate judges can be found in any current edition of the Oregon Blue Book. The Court of Appeals was established only in 1962. The Supreme Court, which began under the Provisional Government in 1841, was the only appeals court for most of Oregon's history.

Oregon trial courts consist of municipal, justice of the peace and district courts (which decide minor civil and criminal violations or misdemeanor cases), and of the circuit courts, which are the courts of general jurisdiction which decide the major civil and criminal cases. For some minor of fenses tried in the lowest courts, there have existed various appeals to the circuit courts. The Supreme Court has original jurisdiction in a very few cases. The Tax Court was created in 1961. Especially for non-lawyers, it is worth noting that the growth of administrative agencies has created a large number of hearings procedures, boards and of ficers, with a specialized process for appeal from each. These include planning boards, local tax boards, state agencies such as Adult and Family Services or Childrens' Services, the Land Use Board of Appeals, State Land Board, etc. Legal cases can now occur before a bewildering variety of entities besides the courts.

Ah Lee vs State 8 Or. 214 (1880). Common law rule, that non-believer in Supreme Being incompetent to testify, abrogated by Oregon Constitution: dying declaration of Chinaman admissable.

Andrews vs. Sercombe. 82 Or. 616 (1917). Conveyance under church discipline is valid in the absence of a statute to the contrary.

Antelope, City of vs Rajneeshpuram On appeal to Court of Appeals. (1985). Ownership of church building in Antelope challenged, even though unquestioned for years before Rajneeshees took over town. City in 1981 sold church building to Episcopal Diocese of Eastern Oregon.

Archdiocese of Portland vs Employment Division 42 Or. App 421 (1979). Church schools are covered under FUTA.

Archdiocese of Portland vs Department of Revenue. 5 OTR 111 (1972). Under ORS 307.130, advancement of religion held to be charitable, so that chancery offices and Catholic Sentinel of fices are exempt from taxation.

Allen vs Watson U.S. District Court Oregon - Civil 1985. ACLU alleged religious discrimination existed where American Indians in segregation unit were denied access to sweat lodges and to visits by "pipe holder".

Baer vs City of Bend 206 Or. 221 (1956). Noted in 55 Michigan Law Review 130, and in Antieau at 251. Floridation of city water held not unconstitutional against an attack on religious grounds. Charles Hinkle has stated that Salem Academy might compel different result.

Banks vs Community Church of La Grande 178 Or. 1 (1946). A property conveyance deed was held invalid because there was no notice to all members in accordance with church usages which were held to have the effect of bylaws. 
Barnett vs State. 249 Or. 226 (1968). Manslaughter by abortion. Article 1, Section 6 . Whether it would prevent defendant from receiving fair trial cannot be raised by demurrer.

Barnett vs State. 251 Or. 234 (1968). Article 1, Section 6 does not prevent a prospective juror from being asked his religious belief.

Berean Fundamental Church Council vs Braun. 281 Or. 661 (1978). Held that the real property of local church was held in trust by the national ruling body for the benefit of the local pastor, local council and congregation.

Board of Publication of Methodist Church. 1 OTR 413 (1963). Federal Law uses "destination-of-benefits" test, to determine whether property or enterprize is tax exempt, BUT Oregon employs test of strict construction which looks to actual use.

Board of Publication of Methodist Church vs Tax Commission. 239 Or. 65 (1964). Oregon does not recognize "destination of income" test, but uses rule of strict construction and looks to actual use.

Boyle vs Medford School District. (1985). ACLU challenged allowing onpremises after-class religious instruction to first and second graders in a public school (unfiled).

Brunswick-Balke-Collander-Co. vs Evans 228 F 991 (DC Or. 1916). The federal constitution and laws do not protect religious liberty or impose any inhibition on the State. This is left exclusively to state constitution and laws. Held that the Sunday Closing Law, L.O.L. 2125, does not violate Oregon Constitution Article 1, Section 3.

Chrisman vs Sisters of St. Joseph of Peace 506 F2d 308 (1974). The HillBurton Act, a federal law for hospital construction, which prohibited courts from using receipt of Hill-Burton funds as a basis for compelling an individual or hospital to perform sterilizations when prohibited by the hospital on the basis of religous belief or moral conviction, does not violate federal establishment clause.

Christian Pre-school and Stone Church vs Department of Revenue. 5 OTR 8 (1972) A claim that a church school improperly competed with a private daycare was rejected. Christian school was found to be exempt from taxation.

Christian Retreat Center vs Board of Commissioners for Washington County. 28 Or. App. 673 (1972). An ordinance which authorized denial of church and accessory use permit where the probable needs of the public would not be served was a valid and reasonable limitation on religious practice.

Christofferson vs Church of Scientology. 57 Or. App. 203, rev. den. 293 OR 456 (1982). On first appeal, jury verdict reversed because inquiry into sincerity of religious beliefs had been allowed. On remand, jury assessed damages of $\$ 39$ Million against church for fraud and abusive practices. Judge then granted motion for new trial after finding prejudicial argument and improper inquiry into religion.

Cogan vs Atiyeh. D. Or (1982). Case dismissed upon agreement after 
denominational colleges withdrew from program which gave scholarship tuition aid to students attending any Oregon college. Case brought by ACLU, which had approved statute in 1972 .

Cooper (aka Khalsa) vs Duncan. In court of appeals and federal court. (1981). Sikh teacher was dismissed from teaching and lost teaching certificate because wore Sikh headgear in school. Appeal to Education Department lost, and cases filed in both state and federal court. Agreement was return of certificate where teacher agreed not to return to State. Appeal: Court sustained prohibition, but rejected penalty. That decision is on appeal to Oregon Supreme Court.

Cooper vs Oregon School Activities Association. 52 Or. App 425 (1981). OSAA rule which required that transfer students not participate in sports for one year after transfer held not to violate free exercise and equal protection clauses when applied to transfers from parochial to public high schools.

Corporation of Presiding Bishop of Church of Latter Day Saints vs Department of Revenue. 6 OTR 268 (1975), 267 Or. 775 (1976). A farm, whose income went entirely to charity, was itself held not exempt from state taxation. Oregon is not a "destination of income" state, and an exempt organization cannot run a business for profit and avoid taxation by passing profits through the organization.

Dallas City vs Missionary Society of the Methodist Church. 6 F 356, af fd.107 US 336 (1881) A grant to religious societies of mission stations was not restricted to a single one for each, but for as many as they actually occupied, based upon federal Act of 1848 (August 14), 9 Stat. 323, Sec.1.

Damascus Community Church vs Clackamas County. 45 Or. App. 1065, appeal dismissed. 450 US 902 (1980). A zoning ordinance which allowed churches and parochial schools as a conditional use in land use law was not a violation of free exercise of religion where procedure was fair.

Decker vs Berean Baptist Church. 51 Or. App. 191 (1981). Civil courts may not enquire into church doctrine to resolve church disputes (American Rule).

Dickman vs School District 62 C. 232 Or. 238 (1962). cert. denied 371 US 823 (1962). The Oregon Constitution was held to forbid free textbooks to religious schools. The "student benefit" theory was rejected under the State Constitution, although the federal Constitution would allow it.

Diocese of Oregon (Protestant Episcopal Bishop) vs Department of Revenue. 5 OTR 126 (1972). Companion case to Archdiocese of Portland. Gift of the Kerr Residence, used as the diocesan administrative center, held exempt from taxation.

Dilger vs School Distriet 24 CJ. 222 Or. 108 (1960). ORS 339.420, which allowed released time for religious instruction and required school districts to provide, approved as constitutional.

Dillon vs Watson. US Dist Or. (1985). Right of minister to conduct nondenominational classes and to proselytize within prison approved. 
Eberle vs Benedictine Sisters. 235 Or. 496 (1963). Held that it was a jury question whether quality of glass in window of church falls below community standards applied to religious entity same as for other entities.

Estabrook vs State 162 Or. 476 (1939). Although at common law witness who did not believe in Supreme Being was incompetent to testify, that was changed by Oregon Constitution. Inquiry into beliefs of Christian Scientist resulted in reversal.

Bvangelical Lutheran Good Samaritan Society vs Department of Revenue. 5 OTR 14 (1972). Receipt of net income by a charitable or religious entity does not render it non-exempt from taxation; it is not to be punished for prudential management.

Evangelical Lutheran Charity Board vs Department of Revenue. 4 OTR 410 (1971).

On tax exemption, Oregon is a "strict construction" state: Land held for future use is not exempt.

(First) 1st Evangelical United Brethren Church vs Department of Revenue. 1 OTR 249 (1963). Church property is not exempt from taxation where legal title is held by trustees. Oregon applies the maxim that ad valorem taxes are concerned only with legal title.

Fisher vs Clackamas School District 1213 Or. App. 56, rev. denied (1973). The court approved "released time" (religious education of $\mathrm{f}$-school premises), but rejected "shared time" (joint use of premises by religious entity and public school entity). Public school had contracted with Catholic parochial school to hold its classes on parochial premises to parochial students during part of time. School found not to be genuinely public, because church chose who could attend.

Freeland vs State 295 Or. 367 (1983). It would violate Oregon Constitution Article I, Section 20, to grant or deny a preliminary hearing because the accused was of a particular religious denomination.

German Apostolic Church vs Department of Revenue. 6 OTR 521 (1976). A change in ORS 307.140 held to widen concept of "use" under Oregon tax law. The principle of apportionment applies, so that portions used for church activities were held exempt, but not apartments.

Goodall vs State. 1 OTR 333 (1857). That deceased did not believe in future reward or punishment was held relevant to the credibility of a dying declaration. The Oregon Constitution was not raised in this case.

Gregory vs Salem General Hospital. 175 Or. 464 (1945). Held that the statute of 1872 applied only to the formation of ecclesiastical corporations. Public hospital held to fall under rule that charitable institutions are exempt from liability for torts arising out of negligence. Exemption from such liability is not dependent upon whether an entity is religious but whether it is charitable.

Harrisburg Lumber Co vs Washburn. 29 Or. 150 (1896). Lien on church valid and not exempt (Methodist Episcopal Church). 
Hertzka vs State (1900). Christian Scientist was accused of practicing medicine without a license, where woman died after all doctors had given up and C.S. provided treatment. Found guilty before Justice of Peace, but not guilty on retrial in Circuit Court in Clackamas County.

Hibemian Benewolent Society vs Kelly 28 Or. 173 (1895). Case set apportionment rule for exemption of charitable enterprises from taxation. Charity can restrict benefits to members. Oregon statute deals with property as it finds it and not with future uses. But case dismissed, because court of equity will not enjoin collection of tax, which is for court of law.

Hosmer vs State 72 Or. Report 57-77. (1914). Libel case where Catholic Convent was libelled by newpaper editor who published false accounts of "escaped nun". The editor's conviction was affirmed on appeal.

Jehovah's Witnesses vs Mullen. 241 Or. 281 (1958). Municipality did not impermissably discriminate where upon full and fair review it declined to allow variance to construct meeting hall in residential area.

Jensen vs State ex rel Juvenile Department. 54 Or. App (1981). Parents' free exercise objection to traditional medical treatment would not prevent court from assuming jurisdiction over hydroencephalic child for purposes of obtaining possible life-saving treatment. Treatment of such child by prayer only, while statute relieved parents of charge of child abuse, exceeded limits.

Kay us David Douglas High School. Multnomah County Circuit Court (1984). Court forbade prayer at high school baccalaureate service.

Kelly vs Commissioner. 62 T.C. 131 (1974). All persons are taxable on income earned in individual capacity, as opposed to income earned as agent of church.

Kemp vs Workers Comp. 65 Or. App. 659, modified. 67 Or. App. 270, rev. denied. 297 Or 227 (1984). Rule that Workers Compensation claimant can only refuse treatment when relying upon an accredited practicioner of a wellestablished church violates Oregon and U.S. Constitutions.

Liggett vs Ladd. 17 Or. 89 (1888). The property of an unincorporated religious association was conveyed to a literary association which was required to hold it for the benefit of the religious association. Arrangement held valid.

Lenrich Assoc. vs Hayden. 264 Or. 122 (1972). Hare Krishna devotees could not require owners of private shopping mall to allow them access for solicitation and display of belief before public. Based on Hloyd $v$ Tanner case.

Lowe vs City of Eugene. 254 Or. 518 (1969). Eugene Sand and Gravel v Eugene 276 Or. 1007 (1977). The Eugene Cross Cases. Courts with different members first found that cross on public park was permitted, then forbidden, and finally permitted as a secular symbol to war dead. Case was 8 years in courts.

McElwin vs Kabatoff. 275 Or. 393 (1976). Court refused to allow 
interrogation of jurors after verdict in personal injury case where Plaintiff testified that she had attended Jehovah's Witness' service prior to accident.

MeGahen vs Commissioner. 76 T.C. 468 (1981). All persons as individuals are taxable on income (as opposed to whether or not taxable as agents of church).

Marks vs City of Roseburg. 65 Or. App. 102 (1983). Gypsy fortune telling case. City's occult arts ordinance prohibiting fortune telling held invalid because focused on content of speech and writing.

Methodist Book Concern vs State Tax Commission. 186 Or. 548 (1949). Oregon applies strict construction of tax law.

Methodist Episcopal Protestant Church at Jefferson vs Adams. 4 Or. 76 (1870). A religious corporation, under Misc. Laws Chap 3, can receive bequest.

Miller vs Employment Division \& Union Gospel. 45 Or. App. 1117, 290 Or. 285 (1981). Truck driver and related enterprises of church held not subject to state employment tax.

Methodist Home Inc. vs Tax Commission. 226 Or. 298 (1961). Nursing home operation held not exempt from taxation, under principle it was ordinary business although run by church.

Multnomah School of the Bible vs Multnomah County. 218 Or. 19 (1959). "Strict but reasonable construction" case. Exemption would be granted where initial steps were taken showing clear intent to use for charitable purposes.

Murphy v Harty, 238 Or. 228 ( ). A judgement of $\$ 10,000$ for libel was given to Murphy when another minister referred to him as a liar and accused him of carrying out "Satan's plan of division and destruction." The Court found that communications in the course of church discipline were privileged, but that a finding of actual or express malice could override the privilege.

Napier vs First Congregational Church of Portland. 157 Or. 110 (1937). A tort ease, where the court determined that an "invitee" became a mere "license" when he sought the church lavatory.

Nelson vs Monitor Congregational Church. 74 Or. 162 (1914). A grantor of property to a church cannot sue to regulate its use unless he is a church member.

Newton vs Cupp. 3 Or. App. 434 (1970). Protection of religious freedom is one of the obligations of all courts.

Employment Division vs Northwest Christian College. 31 Or. App. 201 (1977). The court held that church schools were not covered under FUTA.

Ex Parte Northrup. 41 Or. 489 (1902). Statute prohibiting barbering on Sunday held to be constitutional.

Pacific Conference of Evangelical Churches vs Department of Revenue. 7 OTR 429. Jennings Lodge Conference Center was held not exempt where no timely 
application was made (though it might otherwise have been exempt). Estoppel not available in tax area, even though failure to file was based upon advice of official.

Palmer vs State. Oregon Sp Ct. (1866), p 91 of Acts \& Res of Leg. Assembly. WA McPherson, State Printer. Incorporation of city of Salem did not invalidate Act of January 1854 to prevent Sabbeth-breaking and barroom regulation.

Pennoyer vs Wadhouse. 20 Or. 274 (1891). A devise was held to be for public charity when it was for the advancement of religion by construction of a (Presbyterian) church.

Philomath College vs Wyatt. 27 Or. 390 (1893). American courts will not interfere in ecclesiastical disputes. Church of United Brethren in Christ. After announcing non-involvement principle, court conducted extensive review (which was also occuring in many other states) and determined that those who left church had no claim where substance of doctrine and original church constitution was adhered to.

Pierce vs Society of Sisters. 268 US 510 (1925). U.S. Supreme Court struck down state initiative law which would have required that all children attend public schools in the English language only.

Planned Parenthood vs Department of Human Resources. 63 Or. App. 41 (1983), aff 297 Or. 562 (1984). The claim by plaintiffs that rule limiting abortions was invalid because it violated religious freedom was not reached by courts, which struck down rule based on other reasons.

Poe vs State Treasurer. 144 Or. 561 (1933). Gift by will to First Church of Christ Scientist for Christian Science Monitor was found to be religious and therefore exempt.

Presbytery of Willamette vs Hammer. 235 Or. 564 (1963). A conveyance to trustees without an express statement still created a trust but did not limit use of property.

Reorganized LDS vs Department of Revenue. 6 OTR 510 (1976). Recently acquired property was held to be exempt from taxation, in spite of "use" rule, where the delay in use was unavoidable because of necessary seeking of permits. The minimum requirements of "use" were held to exist.

Boman Catholic Bishop vs Baker. 140 Or. 600. (1932). (Cf. Antieu at 257). Where public schools were permitted to exist, exclusion of parochial schools was held invalid.

Rombough vs Department of Revenue. 293 Or. 477 (1982).

Russell vs Congregation Nevah Zedeck. 236 Or. 291 (1964). A synagogue was held not to be in breach of contract when it spent five months in good faith effort to get approval of site for construction of building.

St. Louis Union Trust Co. vs Oregon. Annual Conference of Methodist Episcopel church. 14 F. Supp 35 (DC Or. 1936). Assumption of debt by 
church is binding.

Scott Co. vs Roman Catholic Archbishop. 83 Or. 97 (1917). Where a deed contained a restriction limiting property use to residential property, but corporation waived this in stipulation, objection by other landowner held not effective and rights to use some property for church and school purposes approved.

Shiloh Lutheran Revival Center vs Bmployment Division. 44 Or. App. 81 (1980). Superceded by Miller. Non-profit religious organization was found subject to unemployment tax, when it was of a type normally done for profit and not integral to religious purposes.

Sisters of Charity vs Washington County Board of Commissioners. 3 OTR 106 (1967). Organization must file on time to receive exempt status. The proper place to apply/appeal is to Tax Commission for review.

Corporation of Sisters of Mary vs Lane County. 123 Or. 144 (1923). Hospital is charitable and exempt from taxation, even though some of patients are able to pay: question of exemption is purely legislative question.

Society of St. Vincent de Paul vs Department of Revenue. 5 OTR 611 (1974). Land merely held with intent to use for charitable purposes is not exempt from taxation where no alteration or actual use for such purpose has begun.

State vs Sprague. 25 Or. App. 621 (1976). Parents must support children regardless of religious beliefs.

Stansberry vs First Methodist Episcopal Church. 79 Or. 155 (1916). First Methodist Episcopal Church. Conveyance which created trust for church was not necessarily perpetual but left discretion in church managers to close and sell after good faith use.

Summers vs Grant Park Baptist Church. 243 Or. 362 (1966). A railed lightwell was held not to be a dangerous condition, so that church as matter of law was held not liable for negligence when 5 year old fell in.

Taylor vs Cupp. 29 Or. App. 585 (1977). Prison regulation prohibiting more than certain quantity of books and publications in cell not deemed denial of free exercise of religion: a proper limitation based upon security, and not a prohibition.

Thornton vs City of Portland. 174 Or. 508, 149 P2d 972 (1944). State can forbid children of Jehovah's Witnesses from being put out to sell literature. Based on U.S. Supreme Court case of Prince v Massachusetts, 321 U.S. 158 (1944). Court held that Oregon and U.S. Constitutional provisions on religion, though in different words, were the same.

Tijerina vs Cornelius Christian Church. 273 Or. 58 (1975). Church land was held not to be "agricultural land" so as to immunize church for liability for negligence, when it acquired farm land but was using as baseball field, and plaintiff injured by falling in unmowed weeds.

Tooley vs Martin-Marietta Corporation. 648 F2d 1239, cert. den. Steelworkers 
of America v Tooley, 454 US 1098 (1981). Section of U.S. Civil Rights Act, which allowed Seventh Day Adventists to pay the equivalent of union dues to mutually acceptable charity, was held to be valid. Oregon has similar statute.

US vs Bigman. 429 F2d 13. cert. den. 400 US 910 (1970). Selective Service compulsory regulations are not a violation of the free exercise clause of U.S. Constitution.

US vs Crowhurst. 629 f2d 1297, cert. den. 449 US 1021 (1980). Argument by defendant that Tax form 1040, with its definition of gross income, forced him to lie and thus violate his freedom of religion was held to be frivolous.

US Bank of Portland vs Snodgrass. 202 Or. 530 (1954). An inheritance contingent upon recipient not becoming or not marrying a Catholic was held to be valid. Acts of private parties are not regulated by constitutional provisions, which are a limit on government.

Wells vs Ivancie. Multnomah County Circuit Court, Portland. No. A83-0402710. (1983). Prayer service at city hall under sponorship of Mayor not permitted, but service on adjoining city park approved.

State us Yee Gueng. 57 Or. 509 (1910). Evidence that deceased did not believe in future rewards or punishments may not be considered in bearing on the credibility of a dying declaration (based upon Oregon Constitution). 


\section{(d) OREGON ATTORNEY GENERAL OPINIONS}

The first Oregon Attorney General was George E. Chamberlain (from 1891-1895). His successors were: Cicero Idleman (1895-1899), D.R. Blackburn (1899-1903), A.M. Crawford (1903-1915), George Brown (1915-1920), I.H. Van Winkle (1920-1943), George Neuner (1943-1953), Robert Thorton (1953-1969), Lee Johnson (1969-1977), James Redden (1977-1980), James Brown (19801981), and David Frohnmeyer (1981 to date). Chamberlain, Thorton, Redden and Brown were Democrats.

2 Opinion Attorney General 71 (1905). State may have displays and exhibits on religion at Exposition.

2 A.G. 178 (1905). A religious corporation can dissolve voluntarily by surrendering its franchise.

10 A.G. 33(1920). Pupils of parochial school can not claim benefits of school transport law designed exclusively for public schools. Parochial students going same way at same time may be accommodated and allowed use of bus.

10 A.G. 451(1922). Workmen who donate their services in building construction for religious organization may be covered by Workman's Compensation Law.

10 A.G. 453(1922). Hotel managers may be criminally liable under Oregon Laws Section 2126 if they permit or aid barbering on Sunday.

11 A.G. 150(1923). Question, of whether property owned by Presbyterian and Catholic Churches is taxable, is not answerable based on the limited facts presented.

11 A.G. 159(1923). Statute (Chap. 11, G.L. 1923, H.B. 18) prohibiting any teacher from wearing religious garb in school is plain and unambiguous, so that there is no authority in the Governor (Pierce) to allow of any exception or suspend its operation. The law provided that the teacher would be suspended and his license revoked. Failure to comply by a school board is misdemeanor.

11 A.G. 199(1923). Compulsory school law (Chap. 1, G.L. of Oregon) does not affirmatively forbid sending children to private schools, but only requires that they attend public schools.

11 A.G. 567 (1924). In absence of statutory procedure for voluntary dissolution of religious corporation, general law applies, so that voluntary surrender, death of all corporate members, or termination by legislature would suffice.

12 A.G. 14(1924). Proposed gift of money by Baptists, for purchase of land and erection of cottage for childrens' farm home, deemed sectarian and impermissable where Baptists imposed condition of gift that they control nomination of matron, name of cottage, and tenure of vacancies.

12 A.G. 408(1925). Oregon Laws Sec. 4235 provides that the land, building 
and contents of churches are exempt from taxation, but by law they must be so used on Tax Day (March 1) to be exempt. There is no relation back, if later used as church.

13 A.G. 10(1926). Trust provision in deed of lots to Methodist Episcopal Church includes power to dispose if proceeds used for trust purpose, where no specific language or power of revert or included. Based upon Stansberry v First M.S. Church.

13 A.G. 237(1927). A Catholic Sister cannot do practice teaching in public school in religious garb. Chap. 11, G.L. of 1923. O'Connor $v$ Hendrick, 184 N.Y. 421 cited as authority.

13 A.G. 587 (1928). Appropriation of school funds by public school directors for maintenance of weekday schools of religion would violate Art. 1 , Section 5. Chap. 24, GL of 1925 allows released time, but nothing allows public funding.

14 A.G. 47(1928). Motor vehicle owned by church not exempt from registration fees even though used to transport school children. A church is not a political division of the state, so as to be exempt from that law.

15 A.G. 403(1931). Bequest to First Church of Christ Scientist, to be used for the Christian Science Monitor, is subject to inheritance taxes. Oregon Code 1920, Sec. 10-601 requires use within State or United States, whereas the Monitor is "an International Newspaper". But a Multnomah County Circuit Court had held such a request to be exempt.

15 A.G. 780(1032). Methodist Episcopal Church: annuity between church and individual not taxable tranfer under state inheritance law, but held to be an inter vivos gift.

17 A.G. 102(1934). Catholic Church (exempt), convent (exempt), schoolyard and Playground (exempt), parsonage to be apportioned (not exempt as parsonage, but exempt to extent used as school) under principles of Benevolent Hiberian Society $v$ Kelly.

16 A.G. 537(1934). Bequests to Catholic Church for masses for dead are for religious use and thus exempt from inheritance tax under Oregon Code 1930, Sec. 10-601.

17 A.G. 468(1935). Under Oregon Code 1930, Sec. 35-1010, which sets property qualifications for voters in school elections, Catholic Sisters cannot vote because they do not own property (all of which is solely owned by their corporation).

17 A.G. 614 (1935). A church manse or parsonage owned and maintained by a church as home for pastor is not exempt from taxation. Oregon law exempts only property actually used for worship. Oregon Code Sec. 69104, as amended Oregon Laws 1931, Chap. 358.

19 A.G. 439(1939). Oregon Laws 1939, Chap. 352, provides that school board shall provide transportation to private or parochial schools under 
compulsory attendance laws (which require public attendance from all between 8 and 16 years of age) but excepts private students who have already acquired learning taught in first 8 years of public school). Chap 352 does not extend to pupils who have learned elementary school.

19 A.G. 479(1939). Legacies to Roman Catholic Archbishop, a corporation sole, held not exempt from inheritance tax under Oregon Code 1935, Sec 10-601, because not made to body corporate and not limited to use solely within the U.S. (and therefore not within terms of statute).

19 A.G. 565(1940). Missionary Society (unincorporated) of Evangelical Church is exempt from inheritance tax law. Oregon Code 1935, Sec. 10-601.

19 A.G. 565(1940). Following Gobitis decision, state may require flag salute and pledge of allegiance without violating religious liberty and rights of conscience. Art. 1, Sect. 3. Discusses cases involving Jehovah's Witnesses.

20 A.G. 105(1940). Non-high school districts may not use school funds to pay tuition, transportation, board or lodging of pupils at tending private (or parochial) schools of high school grade. Student benefit theory rejected. Said that courts of country unanimous in prohibiting use of public funds to pay for private or sectarian schools.

20 A.G. 577(1942). OCLA Sec. 23-927, nuisance statute, does not prohibit peaceful distribution of religious literature on public street by Jehovah's Witnesses. Based on Cantwell v Connecticut, 310 U.S. 296(1939) and Chaplinsky v New Hampshire, (1942), both Jehovah's Witnesses cases.

23 A.G. 473(1948). Released time religious instruction of public school premises under OCLA 111-3014 is legal. On school premises religious instruction is not. Based upon McCollum and State Constitution.

23 A.G. 504(1948). Sec. 111-1021 OCLA, as amended Oregon Laws 1947, Sec. 1, Chap. 72, allows school board to allow equal access to all, including religious denominations. Therefore, school building may be used as church, so long as this does not interfere with school use, where legislature has designed schools as civic centers.

24 A.G. 80(1948). Residuary devise to Roman Catholic Bishop in trust for church and congregation in Hood River is exempt from inheritance tax on OCLA 20-101.

24 A.G. 59(1948). Privately-erected memorial chapel could be built at Oregon State College when open to all students, but college could not employ or pay chaplain. OCLA 111-3802 forbids sectarian test in appointment of employees of colleges, and Art. I, Sec. 5 forbids money for religious institution. McCollum raised a "high and impregnable wall".

25 A.G. 78(1950). OCLA 111-874 and Everson allow but do not require school board to provide for parochial students' transportation (when along or near designated routes) or board or lodging in lieu of same.

25 A.G. 254(1951). School Board not authorized to pay board of student 
wishing to attend parochial school.

26 A.G. 46(1952). Use of Bible in public schools barred by State and Federal Constitutions.

26 A.G. 52(1952). Statutory (Or Laws 1945, Chap 316) and constitutional provisions on religious freedom could allow, if religion required, public school pupil to be excused from running or shower baths. An "apparently absurd question".

26 A.G. 208(1954). Restaurant may not require Negro patrons to eat on one side of the cafe while reserving other side for white patrons, under Oregon Civil Rights Act, ORS 30.670, providing equal treatment in public regardless or race, religion, color, or national origin.

27 A.G. 46(1954). A school board may not arbitrarily refuse to grant at parental request a reasonable time for religious instruction, but may exercise discretion in its manner of doing so. ORS 336.260 and Zorach v Clauson, 343 U.S. 306.

28 A.G. 5(1956). Rule requiring Saturday attendance at Oregon Dental School not invalid as to new students who could not comply with rule because of religious reasons (7th Day Adventists).

28 A.G. 27(1956). It is an unlawful employment practice to ask on an application form if an applicant "regularly attends a house of worship". ORS 659.030 (1) and (3) say so precisely, and ORS 659.020 declares as repugnant to public policy any discrimination based on religion.

28 A.G. 73(1957). Free textbook law permits use by pupils attending private schools which meet state standards. Separate standards may not be adopted for private and parochial schools.

28 A.G. 137(1957). Or. Laws 1957, Chap. 272, the free textbook law, presumed valid, where school boards directly purchase books, so that no expenditure of state funds is involved.

28 A.G. 166(1959). Children of school age attending private or parochial schools may enroll in public high school driver training. One subject to compulsory school law has a right to enroll or participate in part-time instruction.

28 A.G. 257(1958). A non-sectarian chapel at the State boys school at McLaren is permissable. In spite of 1948 ruling that Oregon State College could not have chapel, McLaren could because ORS 421.035 and religious freedom allowed and required, and because Zorach required accommodation. Art. 1, Sec. 5 read to allow employment of chaplains else where than in legislature.

29 A.G. 387(1960). Building owned by religious group and used by religious director as residence not exempt from ad valorem taxes under ORS 307140. Based on Benevolent Hibernian Society $v$ Kelly.

30 A.G. 14(1960). Attorney General will not give opinion to Labor 
Commissioner on whether University of Oregon and Oregon State College may grant recognition to campus groups which exclude from membership on the basis of race, religion, etc., as this does not involve employment practices or places of public accomodations.

30 A.G. 19(1960). The free textbook law, ORS 328.520 , does not permit free use or distribution of other teaching aids to pupils in parochial schools.

30 A.G. 317(1961). Based upon ORS 332.170, school board may permit use of schoolhouse by churches or organized religious groups for a proper purpose under such restrictions, terms and conditions as to compensation as the Board may impose. Cf. 1946-48(505), 1926-28(127), 1934$36(438,737)$, $1936-38(417)$.

31 A.G. 36(1962). Transportation of elementary parochial school students in vehicles used exclusively for union high school district for pupil transport is exempt under ORS 767.025 and not subject to transportation code.

31 A.G. 430(1962). Stay of mandate by Oregon Supreme Court, pending petition for review by U.S. Supreme Court, of Dickman v School District No. 62 (1961) would have effect that textbooks in use in parochial schools should not be withdrawn, but no new books should be issued: to preserve status quo.

31 A.G. 296(1963). Resident pupils attending parochial school are entitled to enroll in public schools to at tend select classes. This is subject to reasonable rules and regulations.

31 A.G. 428(1964). It is not a violation of State or Federal Constitution to have clergy and prayer at non-mandatory high school graduation or baccalaureate service. Accommodation to religion permissable even under Dickman.

32 A.G. 209(1965). Use of public schools to distribute Gideon Bibles violates the Federal Constitution (based upon New Jersey case of Tudor $v$ Board of Education).

33 A.G. 351(1967). A grant of Hill-Burton (federal) funds, for construction of care facilities, is constitutional, notwithstanding ownership or operation of facility by church, religious sect or order. There are no state funds, so there is no state violation.

33 A.G. 354(1967). Invocation at student body council meetings and assemblies violates Federal Constitution.

34 A.G. 109 (1968). A proposal to provide funds for students at Oregon private colleges, without distinction as to church affiliation of the college, would be constititional. But see PESIC case, Cogan v Atiyeh, 1982 .

35 A.G. 262 (1970). State may not provide financial assistance to student at or contract with parochial school, but may with other private school.

35 A.G. 483(1971). State may not make tuition grants to or contract with 
religious institutions of higher learning.

37 A.G. $787(1975)$. It is permissable for State Board of Education to set policy that public schools may provide areas for displays of religious and other cultural significance. It is not permissable for volunteer adult to display creche in public classroom.

38 A.G. 1929(1978). ORS 179.375, requiring Corrections and Mental Health Department to provide chaplains "including but not limited to Protestant and Roman Catholic" is not limited to nor gives preference to those. Practice of having chaplaincy open to only one faith is permissable where that is the need.

41 A.G. 281(1980). Teaching scientific creation theories in public school would violate Constitution IF it were found to be religious instruction. "Equal time" for creation theory not required if Darwinian evolution taught. The teaching of creation theory could not be required IF found to be religious instruction.

42 A.G. 44(1981). HB 2633, requiring public schools to give belanced treatment to theories of evolution and scientific creation, probably not constitutional.

43 A.G. 8128(1982). Receipt of state monies by religious organization providing secular service of family counselling is permissable.

43 A.G. 11(1982). A payment of public funds to a religious body for services rendered by the religious body is permissable: Catholic Family Services Program.

44 A.G. 8148 (1983). The City of Rahneeshpuram, concluded to be wholly owned and controlled by a religious group, deemed unconstitutional. Payment of State revenue sharing funds to city not allowable where religiously affiliated corporation owns all property in the city. 


\section{(e) STATE LAWS AND PROPOSED LAWS}

Sources: 23 Oregon Law Review (1943) at 53-55 contains a bibliography of Oregon Statutes to 1940, showing the various compilations, revisions, digests and codes, of the Territory (first in 1850) and then of the State. Under the State were: (1) the 1862 Code; (2) the "Deady Code" of 1866; (3) the Deady and Lane Laws of 1874 ; (4) the Hill Code of 1887 ; (5) the second Hill Code of 1892; (6) the B \& C (Ballinger and Cotton) Code of 1902; (7) Lord's Oregon Laws of 1910 (three volumes); (8) Olson's Oregon Laws of 1920 (two volumes); (9) Clark's Oregon Laws of 1928; (10) the Oregon Code of 1930; (11) the 1935 Supplement by Dyer and Kaufman; and (12) the OCLA (Oregon Compiled Laws Annotated) of 1940. Current laws are found in Oregon Revised Statutes (ORS), which is amended after each legislature.

\section{State Laws and Proposed Laws}

1843. Organic Law. Contained verbatim the words of the Northwest Ordinance.

1845. Organic Law. Contained verbatim the words of the Northwest Ordinance.

1849. Territorial School Law had section protecting religious opinion.

1850s. Law allowed mission to hold township (34,040 acres).

1850. Proposed territorial law to expel Catholic priests because of alleged role in Whitman Massacre failed.

1854. Territorial law established Sunday closing of businesses not for charitable or neccessitous purposes and close regulation of taverns. Carried over in State law and readopted regularly.

1857. Oregon Constitution. Article IX, Sec. 1, authorized immunity of churches, charitable and educational property from taxation. (Removed in 1917).

1857. Oregon Constitution. Article I, contained numerous provisions protecting religious belief.

1870. Mathew Deady responsible for first statute in country allowing corporations to form without a special act of legislature but upon signature of three incorporators, and laws on church incorporation.

1880. A law proposed by the American Protective Association would have prevented the flying of any foreign flag over any public building. It was aimed at preventing the raising of the Irish flag on St. Patricks Day.

1901. There was talk in the 1901 session of a law to outlaw Christian Science, but it never got out of committee.

1915. A bill was introduced by W.P. Lafferty (Benton County) for inspection of convents, monasteries, hospitals and like institutions, both regularly and 
on petition of twenty or more persons.

1917. Oregon Constitution. Article IX, Sec. 1, amended to delete language specifically exempting "religious" and similar entities. Exemption thereafter became statutory only.

1922. Oregon School Bill. Initiative would have required that all children under 16 attend public schools in the English language. Overturned in Pierce $v$ Society of Sisters.

1923. Garb Bill. Forbade any public school teacher from wearing religious garb on penalty of dismissal and loss of certificate, with criminal penalties for Boards who did not enforce.

1923. Proposed laws would have outlawed sacramental wine and made Columbus Day not a holiday.

192X. Law required daily reading of King James Bible in schools.

1925. Law permitted use of public school time (released time) for religious instruction. (Zabel 121).

1941. Law provided for free textbooks and transportation for all students (including parochial).

1953. ORS 336.260 Released time law.

1962. Oregon Constitutional Revision Commission. Commission did not adopt proposed amendment which would have forbidden religion in schools. It did adopt language to Article 1, Sec. 5 which would have broadened it. Commission's recommendations not adopted.

1971. Law allows individuals to refuse without penalty to participate in abortion when religious or moral reasons dictate. Hospital also allowed by law to decline abortion.

1972. Initiative proposed Constitutional Amendment. Article 1, Sec. 1 was to be changed to same language as federal First Amendment. Failed of passage.

Oregon Evidence Code. 5:06. Clergy/Penitent privilege: applies only to formal churches.

ORS 106.120. Clergy of organized congregations may perform marriages.

ORS 243.666. Fair share union dues. Those with religious or comparable objection may pay fair share equal contribution to agreed upon charity in place of union dues.

ORS 657.072 allowed exemption from Unemployment Compensation law for schools connected with organized church (Cf. Salem Academy) and provided tax exemption for minister or member of religious order.

1981-83. ORS 166.155 and 166.165 created crimes of Intimidation. First 
degree intimidation is Class $\mathrm{C}$ Felony. Second degree intimidation is Class A Misdemeanor. Intimidation if person by reason of race, color, religion or national origin violates statutes on harassment, assault, etc.

1985. Statutes aimed at Rajneeshees passed. One prohibits state funding to school districts supporting religious activity. (A serious tool against local option and standing problems). A second, aimed at Rajneeshpuram's summer festivals, gives counties the authority to regulate outdoor mass gatherings. 


\section{(f) LAW REVIEW ARTICLES ON RELIGION}

Oregon has three law schools: the University of Oregon at Eugene, Willamette Law School in Salem, and Lewis and Clark College/Northwestern School of Law in Portland. The latter's journal deals with environmental law. Oregon Law Review began only in 1921. Willamette Law Review began in 1966. The only other state law journal has been the Oregon State Bar Journal, published since 1940, a work of highly irregular content and quality over the years.

16 Oregon Law Review (1936). One article for, and one against, tort immunity for churches. Three cases based on trust fund theory discussed.

18 Oregon Law Review (1938). "Religious Liberty and the Schools". Review of flag salute cases. A note that Bible reading may violate the state constitution (at 125).

21 Oregon Law Review (1941)76. Article on distribution of religious literature by Jehovah's Witnesses.

27 Oregon Law Review (1947) 150. Note on Everson. Cites trend to public support of religion in education. Decision said to turn usually on State Constitutional provisions. Footnote 2 says Oregon Law allows transport to parochial schools.

28 Oregon Law Review (1948). Review of Separation of Church and State in the U.S. 1948 Book by Alvin Johnson and Frank Yost. Pro-separation review, with survey of history and court decisions.

31 Oregon Law Review (1951)78. Article discussing and opposing charitable tort immunity.

33 Oregon Law Review (1953)242. Book Review: Opposes charitable tort immunity.

38 Oregon Law Review (1958)350. 1955 case left to legislature (not the court) question of whether to end charitable tort immunity.

40 Oregon Law Review (1961)274. On validity of released time statute.

43 Oregon Law Review (1965)177. On validity of unemployment compensation statutes compelling work on Sabbath. Note on free exercise and discussion of U.S. Supreme Court case of Sherbert $v$ Varner, 7th Day Adventist case. 
56 Oregon Law Review (Winter 1982) 1. Helen Mazur-Hart. Note on Racial and religious intimidation law passed in Oregon in 1981 session (making violations Class $\mathrm{C}$ felonies and Class $\mathrm{A}$ misdemeanors).

20 Willamette Law Review (Winter 1984) 1. Note on Larkin v Grendel's Den, U.S. Supreme Court case prohibiting delegation of state power to church to veto tavern location. 


\section{(g) INTERVIEWS/SPEBCHES}

Goodwin, Judge Alfred T. 9th Circuit Court of Appeals and former Oregon Supreme Court Justice, Member of Constitutional Revision Commission. Speech to ACLU at 1984 Annual MeNaughton Awards Dinner.

Greek, Adrian, Director of Positive Action Center, Portland cult awareness and monitoring center. Professor of Psychology at Reed College. June 1985.

Hinkle, Charles. ACLU Lawyer, Congregational Minister, expert on First Amendment and law and religion. Speech at Oregon State Bar Program on Oregon Constitutional Law. February 1985.

Linde, Justice Hans. Oregon Supreme Court Justice, Member of Constitutional Revision Commission, noted scholar on development of law under State Constitutions. Speech at Reed College on Oregon Constitution. November 1984.

McKibbin, Margaret. Social worker and interpreter for Old Russian Community in Marion County, Oregon. Lives in Gervais, Oregon, one of Old Russian Believer centers.

Remington, Stevie. Executive Director of ACLU of Oregon since 1973. Numerous discussions, 1978-85.

Saalfeld, Father Lawrence. Catholic priest, author of Forces of Prejudice in Oregon, and participant in Fisher case. Phone and personal interviews. 198485.

Schoenberg, Father Wilfrid, S.J. Jesuit historian of Northwest Province and author of books on religious history of the Northwest. Personal and phone interviews. 1985.

Silverman, Carol. University of Oregon Folklore Department. Prepared film on Russian Old Believers for Oregon Committee on the Humanities (with Margaret Hixon and Margaret McKibbin). Interview, July 1985.

Turner, Thomas. Oregon State Scholarship Commission. Provided background and materials on PESIC case with history of statute, funding, and case. Interview, March, 1985.

Other Interviews: The author has participated in, reviewed, interviewed clients or lawyers in a number of recent cases, e.g. Rristof ferson, Khalsa, Cooper, Kay, etc., and as part of ACLU Lawyers Committee for State of Oregon since 1978 has reviewed most cases that have come up for consideration. 